\title{
The genus Schiffnerula in India
}

\section{VB Hosagoudar}

Tropical Botanic Garden and Research Institute, Palode 695 562, Thiruvananthapuram, Kerala, India

Hosagoudar VB 2011 - The genus Schiffnerula in India. Plant Pathology \& Quarantine 1(2), 131204, doi 10.5943/ppq/1/2/4

The genus Schiffnerula is represented by 80 species in India belonging to the anamorphs Mitteriella (single species, assigned to Schiffnerula ziziphina), Questieriella (10), Sarcinella (39) and the teleomorph Schiffnerula (31). Of these, Sarcinella loranthacearum, Schiffnerula cryptostegiae, Schiffnerula flacourtiae, Schiffnerula lagerstroemiae and Schiffnerula meliosmatis are proposed as new species and a new family, Schiffnerulaceae is proposed to accommodate Schiffnerula. All the taxa are described and illustrated in detail.

Key words - Black mildew - Synanamorphs - Mitteriella - Questieriella - Sarcinella teleomorph

\section{Article Information}

Received 18 August 2011

Accepted 16 September 2011

Published online 29 October 2011

Corresponding author: VB Hosagoudar - e-mail - vbhosagoudar@ rediffmail.com

\section{Introduction}

Black mildews are the fungi that produce black colonies on the host surface. These fungi infect mostly leaves, often soft stems and petioles, and they are host specific. Certain plants such as Maesa indica (Myrsinaceae) are invariably infected with these fungi with the crustose colonies of Amazonia peregrina on the upper surface and woolly colonies of Meliola groteana on the lower surface. In fact, this is the plant that triggered my interest in the black mildews in the Western Ghats region of Peninsular India. Earlier, the term "sooty mould" was applied to both parasitic forms of "black mildews" and the saprophytic forms, which grow on insect secretion or on the nectar producing glands of the plants. Unlike black mildews, the sooty moulds are not restricted to specific parts of the host. Colonies of sooty moulds can develop on leaves, entire growing twig, stem, bark and often extended to nearby plants. Host specificity is missing. A close examination of these colonies in the field will reveal the presence of ants/thrips/small insects moving all over the plants. One can see the sooty colonies wherever these ants or thrips have moved or existed. These colonies can be easily removed by moving fingers over the colonies and the colonies stick on to cloths and hands when handled. In contrast to these, black mildews are very much restricted to the plants (on upper surface of the leaves or lower surface), petioles, etc. Nature of the colonies is also of very much significance. Based on the characters of the colonies, hosts can be identified in the field. The correct identity of the host can be confirmed even in the laboratory. For example, in the Western Ghats region, a member of Sapindaceae infected with Meliola sp., having angular head cells of the appressoria, the host can be determined as Sapindus laurifolius. Since these fungi are host or family specific, it is necessary to identify the host plant. Hence, before entering into any forest area or study of these fungi, it is essential to know the flora of that area or such a venture can be with an angiosperm taxonomist. My experience of more than three and 
half decades with these fungi in the field states that microbes are better taxonomists. The occurrence of the black mildews dates back to Devonian (Eocene and Miocene) period (Dilcher 1965, Martin \& Rouse 1966, Mandal et al. 2011) and they have co-evolved with their hosts, predominantly with flowering plants. Hansford (1946) stated that the host ranges of these species are very small, and the most convenient method of determination is on the basis of their known hosts. Deighton (1944) stated that very limited host range of each species is remarkable and was confirmed by Ciferri (1938) stating that the studies on species of Sarcinella and the Questieriella synanamorphs from North America and Europe have indicated that this approach is applicable at the host genus level, and in some species at the family level. To-Anun et al. (2011) have effectively used this method for the genus Cercospora. Hughes (1983) stated that all morphs are to be taken into an account in the circumscription of the species. Among anamorphs, Sarcinella and Mitteriella species did not reveal their germination process but the Questieriella spores frequently formed colonies.

Taxonomically, black mildews may be meliolaceous, asterinaceous, schiffnerulaceous, hyphomycetous, etc. The fungi with thyriothecium may belong to Asterinales (external mycelium with thyriothecia, which dehisce stellately at the centre or vertically all along the length), Parmulariaceae (external mycelium absent) or Microthyriales (having ostiolate thyriothecium), Meliolales (having two-celled appressoria and unicellular phialides), Schiffnerula (like Asterinales but with unicellular appressoria, having different types of conidial anamorphic states), hyphomycetes (presence of conidia and conidiophores) and so on.

\section{The genus Schiffnerula}

Apiosporium pulchrum Sacc. on Ligustrum vulgare leaves became Dimerosporium pulchrum (Sacc.) Sacc. possessing two types of conidia, one sarciniform and the other falcate (Saccardo 1875). Sarciniform conidia are considered under the genus Sarcinella. Hughes (1983) validated the generic name Questieriella for the falcate forms. Similar kind of straight and oval conidia with 3-5 septation infecting the leaves of Ziziphus spp. (known only on this host genus) are placed under the genus Mitteriella. The monospecific form genus, Digitosarcinella, known to belong to this group. All these four genera: Digitosarcinella, Mitteriella, Questieriella and Sarcinella form the synanamorphs of the teleomorphic genus, Schiffnerula. Because of the similarity, the genus Clypeolella was made synonymous with Schiffnerula (Hughes 1987).

\section{The genus Schiffnerula}

The genus Schiffnerula was placed under the family Englerulaceae (Arx \& Muller 1975), characterized by the globose deluscent ascomata. However, as we learn more and more about this genus, the radiating ascomata develops below the mycelium is the characteristic feature of 'thyriothecium'. Based on this, it can be rightly placed under the family Asterinaceae of the order Asterinales. However, the central portion of the thyriothecia gelatinizes by exposing the asci. Further, the genus supports four synanamorphs and accounts to more than hundred species. With these, I am inclined to accommodate it in a new family, as was done for the genus Meliolina (Hughes 1987).

Schiffnerulaceae V.B. Hosagoudar, fam. nov.

Coloniae foliicolae, nigrae; mycelium brunneum, superficialis, septatum, appressoriatus; appressoria unicellularis, formans lateralis. Thyriothecia orbicularis, cellulae ad supra surfaces radiatus, dissolutus ad centre ad maturitatae; asci globosi, bitunicati, 8-spori; ascosporae conglobatae, brunneae, uniseptatae, constrictus ad septae.

Colonies formed on the leaf surface, black; mycelium brown, superficial, septate, appressoriate; appressoria unicellular, formed laterally. Thyriothecia orbicular, cells on the upper surface radiating, dissolute at the centre at maturity; asci globose, bitunicate, 8-spored; ascospores conglobate, brown, uniseptate, constricted at the septum.

Type genus - Schiffnerula Hohnel (Synamorphs - Digitosarcinella, Mitteriella, Questieriella and Sarcinella).

\section{Developmental studies}

It is very common to see that Questieriella conidia germinate by collapsing the terminal 
cells or by the terminal cells producing promycelium and then appressoria. Germination of Sarcinella and Mitteriella conidia are yet to be understood. However, it was possible to observe the developmental stages in the thyriothecium.

\section{Methods}

While collecting the infected plant parts, field notes were made regarding their pathogenicity, nature of colonies, nature of infection, locality, altitude, etc. For each collection, a separate field number was given. In the field, such infected plants were collected separately in polythene bags with the host twig (preferably with the reproductive parts to facilitate the identity of the corresponding host). At the time of collection, tall trees pose difficulty in noticing the disease. In such cases, recently shed leaves were examined, collected, the concerned tree was traced, a twig or the twigs with reproduc-tive parts were collected for the host identity. These infected plant parts were pressed neatly and dried between blotting papers. Regular transfer of the collections to fresh and dry blot-ters ensured the dryness of the collections.

In evergreen forests, where sunlight is not accessible, leaves of the herbaceous or shrubby plants reveal black mildew-like colonies. Careful observation with a pocket lens will reveal that they are algal colonies, which can be easily removed by thumb nail.

Initially, in the laboratory, colonies were mounted in $10 \% \mathrm{KOH}$ solution by taking scrapes of the colonies and later the mountant replaced by lactophenol/lactoglycerol to make the septa visible. Both these mountants work well in clearing the dark melanin pigment.

To study the entire colony in its natural condition, a drop of high quality natural coloured or well transparent nail polish, devoid of gilt but having the property of fast drying, was applied to the selected colonies and carefully thinned with the help of a fine brush without disturbing the colonies. The treated colonies with their host plants were kept in dust free chamber for half an hour. When the nail polish on the colonies dried fully, a thin, colourless "film or flip" was formed with the colonies firmly embedded in it. In case of soft host parts, a slight pressure on the opposite side of the leaves and just below the colonies lifts the flip up. In case of hard host parts, the flip was eased off from the edge with the help of a razor or scalpel. A drop of DPX was spread on a clean slide and thus lifted flip was spread properly on it. One or two more drops of DPX were again added on the flip and a clean cover glass was placed over it. A gentle pressure on the cover glass brought out the excess DPX and was easily removed after drying. Care was taken to avoid air bubbles. These slides were labelled and placed in a dust free chamber for 1-2 days for drying (Hosagoudar \& Kapoor 1984). These permanent slides were then used for further studies.

After the study, materials were kept in manifold or butter paper folders. Later, these folders were placed in thick paper envelopes of convenient size with the name of the fungus, host, locality, and date of collection, place of collection and name of the collector with the field number written on the top corner. These envelopes were serially arranged in a rack, based on their collection numbers. Friction between the envelope and the material was avoided to keep the fungal colonies intact. Line drawings were made by using Camera Lucida of mirror type. Materials have been deposited in TBGT (Tropical Botanic Garden and Research Institute) and HCIO (Division and Plant Pathology, Indian Agricaltural Research Institute).

\section{Abbreviations used in the line drawings}

a. Appressoriate mycelium

b. Conidiospores of Mitteriella

c. Conidiophores of Questieriella

d. Conidia of Questieriella

e. Germinating conidia of Questieriella

f. Conidiophore of Sarcinella

g. Conidia of Sarcinella

h. Thyriothecium

i. Ascus

j. Ascospores

\section{Key to the genera}

1. Teleomorph known .....................Schiffnerula

1. Teleomorph not known.............................. 2 
2. Conidia globose, sarciniform, brown to black Sarcinella

2. Conidia not so .3

3. Conidia pale brown, falcate, 3-septate Questieriella

3. Conidia straight, ellipsoidal, 0-4-septate Mitteriella

The monospecific genus Digitosarcinella is not represented in India.

Key to the species based on host and its family

\section{ANACARDIACEAE}

Sarcinella S. odinae

\section{APOCYNACEAE}

Sarcinella

On Carissa S. oreophila

On Wrightia

S. wrightiae

\section{ASTERACEAE}

\section{Schiffnerula}

1. On members of the tribe Vernoniae

S. vernoniae

1. On other members .2

2. Questieriella conidia less than $35 \mu \mathrm{m}$ long... S. ecliptae

2. Questieriella conidia more than $35 \mu \mathrm{m}$ long .3

3. On Wedelia S. wedeliae

3. On Spilanthus S. spilanthi

\section{BIGNONIACEAE}

Sarcinella S. bignoniacearum

BUXACEAE

Questieriella..

Q. sarcococcae

ASCLEPIADACEAE

Schiffnerula

S. cryptostegiae

\section{CAESALPINIACEAE}

Schiffnerula

S. cassiae

\section{Sarcinella}

On Cassia, sarciniform conidia less than $30 \mu \mathrm{m}$ in diameter S. cassiae-fistulae sarciniform conidia more than $30 \mu \mathrm{m}$ in diam.. S. cassiae
On Tamarindus S. tamarindi

\section{CELASTRACEAE}

Schiffnerula S. celastri

Sarcinella

On Elaeodendron S. shamboodarai

On Euonymous S. tandonii

On Gymnospora S. gymnosporae

\section{COMBRETACEAE}

Schiffnerula. S. terminaliae Sarcinella

On Quesqualis S. quesqualidis

On Terminalia S. jarwaensis

EBENACEAE

Sarcinella. S. gorakhpurensis

\section{ERICACEAE}

Sarcinella S. lyoniae

\section{EUPHORBIACEAE}

Questieriella Q. malloti

Sarcinella S. indica

Schiffnerula

On Glochidion. S. glochidii

On Ricinus S. ricini

FABACEAE

Questieriella Q. tephrosiae

Sarcinella S. dalbergiae

FAGACEAE

Sarcinella

On Quercus S. quercina

On Castanopsis S. castanopsidis

FLACOURTIACEAE

Schiffnerula. S. flacourtiae

HIPPOCRATACEAE

Sarcinella. S. hippocrateae

ICACINACEAE

Sarcinella. S. hughesii

LAMIACEAE

Sarcinella. S. colebrookiana

LAURACEAE

Schiffnerula. S. actinodaphnes 
LORANTHACEAE

Sarcinella.

S. loranthacearum

LYTHRACCEAE

Schiffnerula.

S. lagerstroemiae

MELIACEAE

Schiffnerula

S. azadirachtae

Sarcinella. S. cipadessae

MORACEAE

Schiffnerula...

S. fici

MYRSINACEAE

Questieriella

Q. ardisiae

MYRTACEAE

Sarcinella.

S. kamalii

OLEACEAE

Schiffnerula.

S. pulchra

PASSIFLORACEAE

Schiffnerula S. mirabilis

Questieriella.

Q. passiflorae

PERIPLOCACEAE

Schiffnerula

S. cryptolepidis

RHAMNACEAE

Schiffnerula.

S. ziziphi

\section{ROSACEAE}

Sarcinella.

S. prunicola

RUBIACEAE

Schiffnerula

On Canthium

S. canthii

On Morinda.

S. braunii

\section{RUTACEAE}

Schiffnerula

Sarcinella

S. girijae

1. Questieriella conidia absent... S. glycosmidis

1. Questieriella conidia present

.. 2

2. Sarciniform conidia more than $40 \mu \mathrm{m}$ in diameter.

S. atalantiae

2. Sarciniform conidia less than $40 \mu \mathrm{m}$ in diameter

S. limoniae

Questieriella Q. zanthoxyli
SABIACEAE

Schiffnerula.

S. meliosmatis

SAPINDACEAE

Sarcinella

S. allophyli

SOLANACEAE

Schiffnerula.

S. palodensis

Sarcinella

S. raimundi

STRYCHNACEAE

Questieriella Q. strychni

THEACEAE

Sarcinella. S. theae

Schiffnerula. S. camelliae

TILIACEAE

Questieriella Q. grewiae

ULMACEAE

Schiffnerula.

S. hughesii

UNKNOWN Host

Sarcinella.

S. asiatica

URTICACEAE

Sarcinella

On Oreocnide.

S. oreocnidecola

On Pouzolzia.....

S. pouzolziae

VERBENACEAE

Schiffnerula.

S. tectonae

Sarcinella

On Gmelina

S. gmelinae

On Vitex

S. jabalpurensis

VITACEAE

Sarcinella.

S. latifoliae

Descriptions of the genera and species

The genus Mitteriella

Mitteriella Sydow, Ann. Mycol. 31: 95, 1933; Ellis, Dematiaceous Hyphomycetes, p. 228, 1977.

Colonies black. Hyphae superficial, brown, branched, septate, appressoriate. Appressoria lateral, unicellualr. Conidiophores macronematous, mononematous, short, simple. Conidiogenous cells polyblastic, integrated, 
terminal, sympodial, denticulate. Conidia solitary, simple, ellipsoidal to limoniform, black, 0-4-septate.

Type - M. ziziphina Sydow.

This is an anamorph of S. ziziphi.

\section{The genus Questieriella}

Questieriella Arn. ex Hughes, Can. J. Bot. 61: 1729, 1983.

Colonies black, hyphae superficial, brown, branched, septate, appressoriate. Appressoria lateral unicellular. Conidiophores micronematous, mononematous, lateral, 0-2septate. Conidiogenous cells monoblastic to polyblastic, integrated, terminal, lateral or incurporated in the hyphae. Conidia blastic, terminal, solitary, narrowly ellipsoidal to obovoidal, curved, falcate, sigmoid, truncate at the base, 3-septate.

Type-Q. pulchra Hughes.

\section{Descriptions of species}

Questieriella ardisiae Hosag. \& Vijay., Zoos' Print J. 19: 1386, 2004. (Fig. 1)

Colonies epiphyllous, thin to subdense, up to $2 \mathrm{~mm}$ in diameter, confluent. Hyphae straight to substraight, branching alternate, opposite to irregular at acute to wide angles, loosely to closely reticulate, cells $19-24 \times 6-8 \mu \mathrm{m}$. Appressoria alternate, about $2 \%$ opposite, unicellular, globose, ovate, entire, 9-11 × 9-10 $\mu \mathrm{m}$. Conidiophores produced lateral to the hyphae, simple, micronematous, macronematous, 0-2-septate, $12-40 \times 6-8 \mu \mathrm{m}$. Conidiogenous cells terminal, integrated, oval to cylindrical, $8-13 \times 4-8 \mu \mathrm{m}$. Conidia solitary, simple, dry, ellipsoidal, fusiform, falcate, sigmoid, deep brown to pale brown, 3-septate, terminal cells acute at the tip, $40-50 \mu \mathrm{m}$ long, $9-13 \mu \mathrm{m}$ broad at the middle, $3-5 \mu \mathrm{m}$ broad at the apex.

Material examined - India, Kerala, Wayanad, Thenmala, on leaves of Ardisia Solanaceae Roxb. (Myrsinaceae), 24 November 2002, K. Vijayakumar HCIO 44632 (holotype), TBGT 914 (isotype); Chandanathode, 26 December 2002, M. Kamarudeen \& P.A. Jose HCIO 44808, TBGT 1045; Karnataka, Kodagu, Hoddur, on leaves of Ardisia sp., September 21, 2009, Jagath Thimmaiah TBGT 5422.
Schiffnerula robusta Orejuela is known on Rapanea sp. from Columbia (Orejuela 1944) but the present species differs from it in having only an anamorph.

Questieriella grewiae Hosag. \& C.K. Biju, Persoonia 18: 125, 2002.

(Fig. 2)

Colonies amphigenous, often surrounded by yellow haloes, black, dense, up to $5 \mathrm{~mm}$ in diameter, rarely confluent. Hyphae straight, substraight, flexuous to crooked, branching alternate to opposite at acute angles, loosely reticulate, cells $25-32 \times 4-7 \mu \mathrm{m}$. Appressoria alternate to unilateral, scattered, hemispherical, entire, 9-12 × 9-10 $\mu \mathrm{m}$. Conidiophores produced lateral to the hyphae, macronematous, mononematous, simple to rarely branched, 0 1-septate, $16-32 \times 4-7 \mu \mathrm{m}$. Conidiogenous cells terminal, cylindrical, pale yellow, 15-17 $\times 4-7 \mu \mathrm{m}$. Conidia ellipsoidal, falcate, 3-septate, slightly constricted at the septa, terminal cells acute and broadly rounded, pale, middle cells deep brown, conidia 40-48 $\times 11-13 \mu \mathrm{m}$.

Material examined - India, Kerala, Idukki, near Munnar, Mannavan Shola, on leaves of Grewia sp. (Tilaceae), 11 May 1999, C.K. Biju HCIO 43972 (holotype), TBGT 482 (isotype).

This species is known from only a single collection.

Questieriella malloti Hosag. \& C.K. Biju in Hosag., J. Econ. Taxon. Bot. 28: 196, 2004.

Colonies amphigenous, mostly epiphyllous, dense, up to $3 \mathrm{~mm}$ in diameter, confluent. Hyphae substraight to crooked, branching irregular at acute angles, loosely to closely reticulate, cells $12-16 \times 6-10 \mu \mathrm{m}$. Appressoria alternate to unilateral, scattered, brown, ovate, mostly globose, broad based, entire, 9-11 × 8$10 \mu \mathrm{m}$. Conidiophores produced lateral to the hyphae, 0-2-septate, substraight to crooked, mostly simple, rarely branched, 19-24 × 7-9 $\mu \mathrm{m}$. Conidia produced from the pore of the hyphal cells or on the conidiophores, integrated, mostly terminal, rarely intercalary, straight to mostly curved, pale yellow. Conidia produced blastically, pale, ellipsoidal, straight to mostly curved, 3-septate, attenuated towards both ends, obtuse to broadly round at the tips, $36-48 \times 12-15 \mu \mathrm{m}$. 
Plant Pathology \& Quarantine

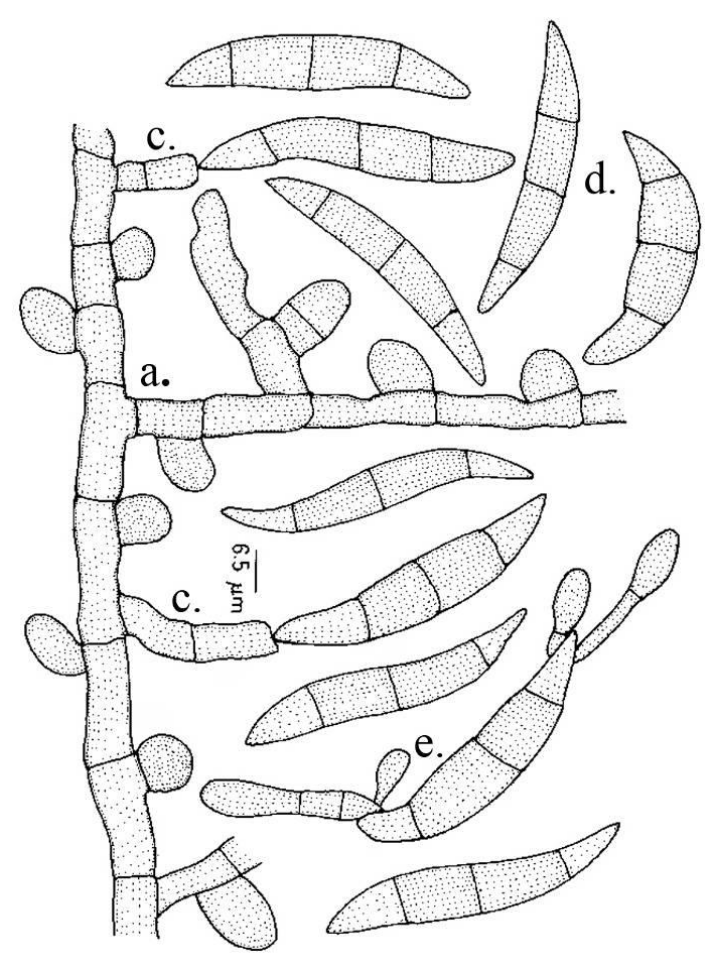

Fig. 1 - Questieriella ardisiae

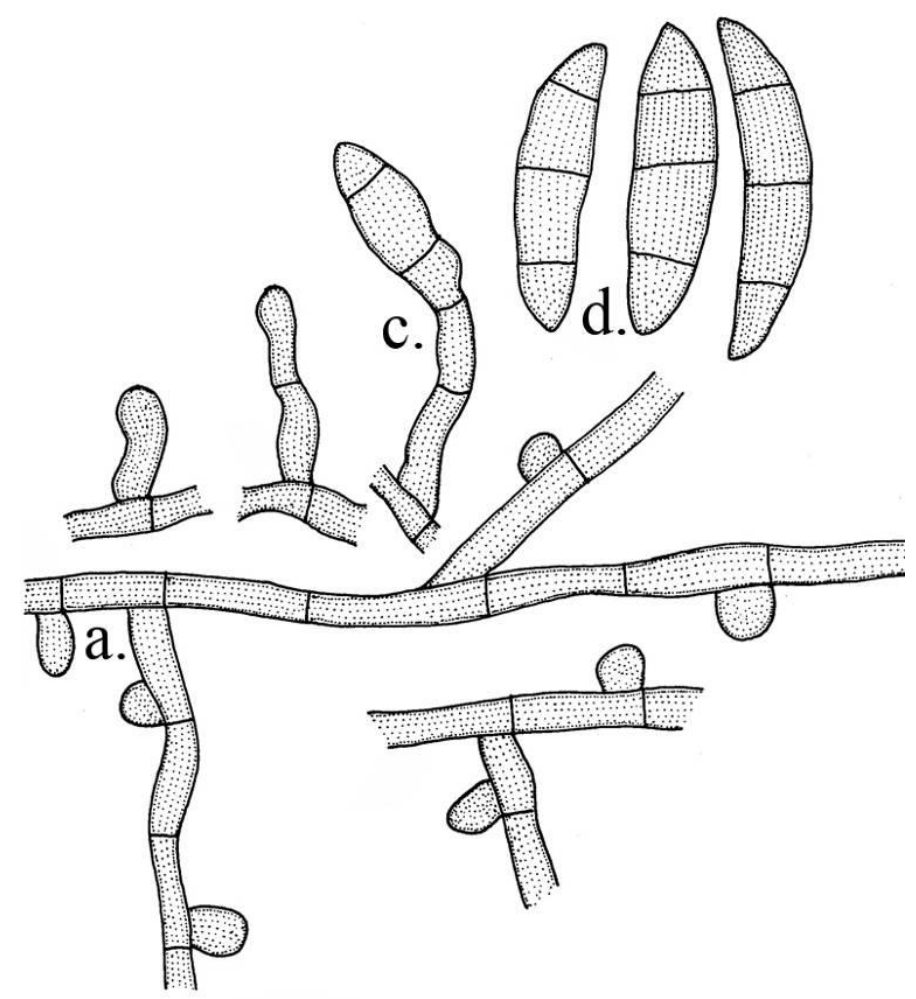

Fig. 2 -Questieriella grewiae 


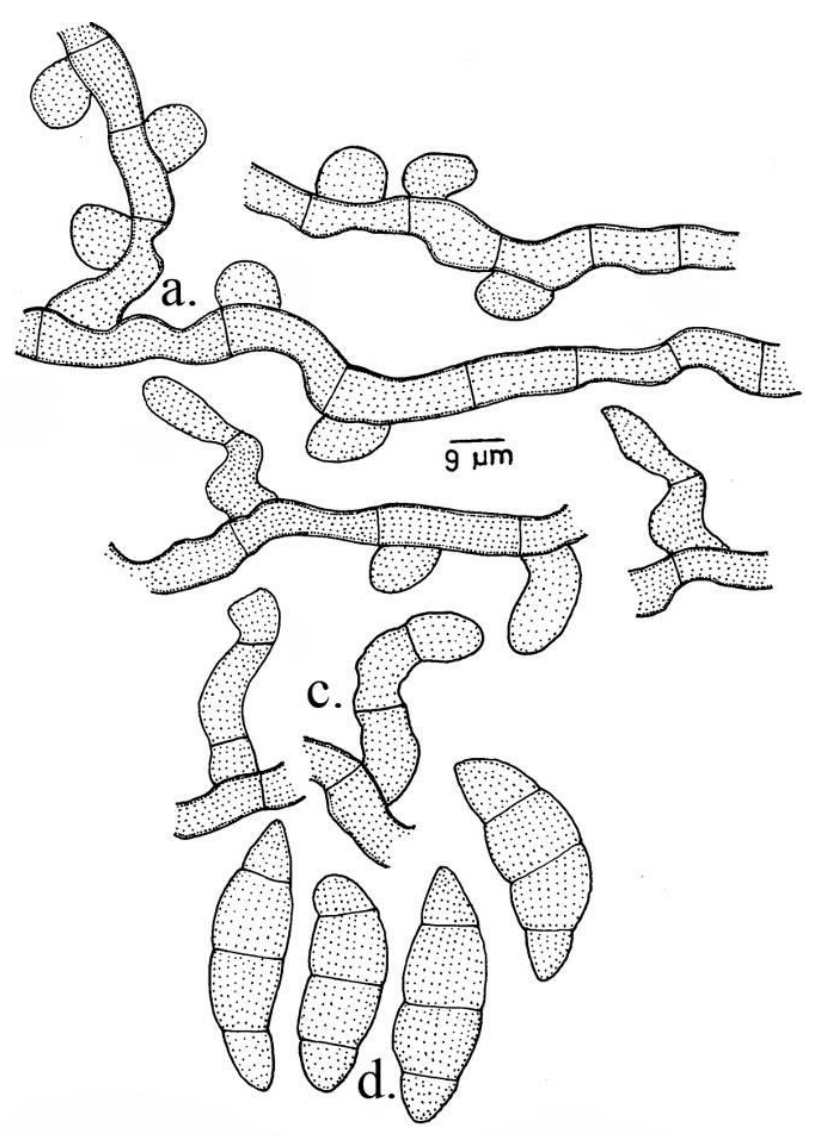

Fig. 3 - Questieriella malloti

Material examined - India, Kerala, Wayanad, Banasuran mala, on leaves of Mallotus philippensis (Lam.) Mull. Arg. (Euphorbiaceae), 19November 2000, C.K. Biju HCIO 44158 (holotype), TBGT 525 (isotype).

This species is known from only a single collection.

Questieriella passiflorae Hosag. \& C.K. Biju, Indian Phytopath. 58: 202, 2005. (Fig. 4)

Colonies epiphyllous, thin to subdense, up to $3 \mathrm{~mm}$ in diameter, rarely confluent. Hyphae substraight, branching alternate to irregular at acute to wide angles, loosely reticulate, cells $12-23 \times 6-8 \mu \mathrm{m}$. Appressoria alternate to unilateral, globose, ovate, entire, 7-9 $\times 8-11$ $\mu \mathrm{m}$. Conidiophores at the tip of the mycelial branch, simple to rarely branched, micronematous, mononematous, 0 -2-septate, $12-30 \times 6-8$ $\mu \mathrm{m}$. Conidiogenous cells monoblastic, terminal, integrated, solitary; conidia ellipsoidal, straight to mostly slightly curved, pale brown, 3 -septate, apical cells paler, attenuated and sharply to broadly rounded at the tip, $27-30 \times$ 9-11 $\mu \mathrm{m}$, wall smooth.

Material examined - India, Kerala, Iduk- ki, Mannavan Shola, on leaves of Passiflora maculifolia Mast (Passifloraceae), 6 January 1999, C.K. Biju HCIO 45194 (holotype), TBGT 1230 (isotype).

Questieriella rhamni Hosag., Ravikumar \& Archana, Zoos' Print J. 22: 2832, 2007.

Colonies epiphyllous, thin, up $2 \mathrm{~mm}$ in diameter, confluent. Hyphae straight to substraight, branching opposite, alternate to irregular at acute to wide angles, loosely to closely reticulate, cells $11-27 \times 4-8 \mu \mathrm{m}$. Appressoria alternate, opposite, unilateral, sessile, globose, entire to slightly angular, 6-10 × 6-11 $\mu \mathrm{m}$. Conidiophores mostly simple, rarely branched, 0-2-septate, slightly constricted at the septa, 14-40 × 5-7 $\mu \mathrm{m}$; conidiogenous cells hyaline, round. Conidia fusiform, curved, 3-septate, slightly constricted at the septa, distal cells obtuse at the tip, 32-48 $\times 9-13 \mu \mathrm{m}$.

Material examined - India, Tamil Nadu, Ooty, Mukurthi National Park, on leaves of Rhamnus wightii Wight \& Arn. (Rhamnaceae), 20 September 2006, K. Ravikumar HCIO 47495 (holotype), TBGT 2533 (isotype). 
Plant Pathology \& Quarantine
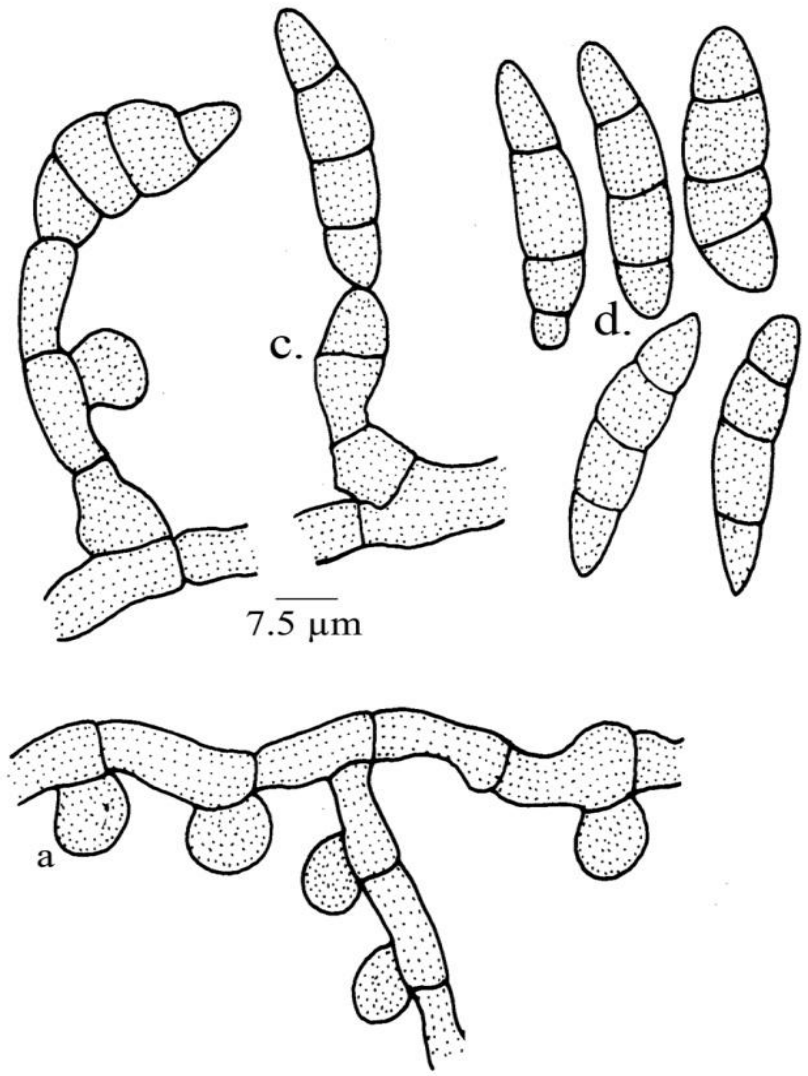

Fig. 4 - Questieriella passiflorae

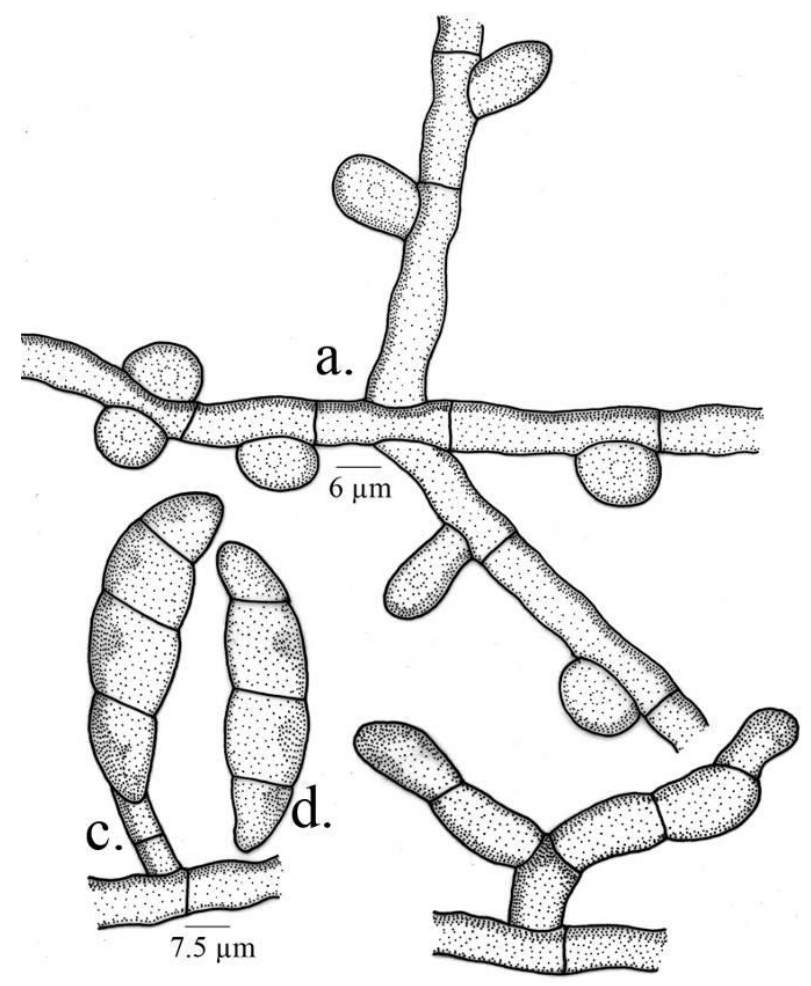

Fig. 5 -Questieriella rhamni 
Clypeolella rhamnicola Doidge is known on Rhamnus prinoides from South Africa (Doidge 1942). The genus Clypeolella is synonymous with Schiffnerula (Hughes 1987). In absence of teleomorph, it has been accommodated in the form genus.

Questieriella sarcococcae Hosag., Manoj. \& H. Biju, Indian Phytopath. 58: 203, 2005.

Colonies epiphyllous, thin, spreading, up to $3 \mathrm{~mm}$ in diameter, confluent. Hyphae straight to substraight, branching alternate to irregular at acute angles, loosely to closely reticulate, cells $16-23 \times 4-7 \mu \mathrm{m}$. Appressoria alternate, about $5 \%$ opposite, oval, globose, entire, $8-12 \times 8-10 \mu \mathrm{m}$. Tip of the mycelium converted as conidiophores, pale yellow, micronematous, mononematous, 0-2-septate, simple, 5-15 × 5-6 $\mu \mathrm{m}$. Conidiogenous cells monoblastic, terminal, integrated, conidia blastic, solitary, fusiform, straight to slightly curved, pale yellow, 3-septate, slightly constricted at the septa, end cells attenuated to broadly rounded at the tip, 45-56 ×9-11 $\mu \mathrm{m}$.

Material examined - India, Kerala, Idukki, Munnar, Gravel bank, on leaves of Sarcococca brevifolia Stapf. ex Gamble (Buxaceae), 20 January 2003, A. Manoj Kumar \& H. Biju HCIO 45225 (holotype), TBGT 1262 (isotype); Tamil Nadu, Kodaikanal, Kukkal Shola, Periyakanal, on leaves of $S$. coriacea (Hook.) Sweet, 7 March 2007, R. Nithyatharani TBGT 4725; 8 July 2007, R. Nithyatharani TBGT 4725, 4488; 14 April 2007, TBGT 4730; 2 June 2008, R. Nithyatharani TBGT 4754; 6 Febuary 2007, TBGT 4767.

All the collection localities are of high altitudinal, with a montane type of vegetation. This species appears to be restricted to these areas.

Questieriella strychni Hosag., J. Econ. Taxon. Bot. 28: 196, 2004. (Fig. 7)

Colonies amphigenous, dense, up to 5 $\mathrm{mm}$ in diameter, confluent. Hyphae substraight to flexuous, branching irregular at acute angles, loosely to closely reticulate, cells $17-21 \times 4-5$ $\mu \mathrm{m}$. Appressoria numerous to scarce, scattered, alternate to about $5 \%$ opposite, globose, entire, $8-10 \mu \mathrm{m}$ in diameter. Questieriella type of conidia produced from the pore of hyphal cells, fusiform, pale brown, 3-septate, straight to curved, sigmoid, often constricted at the middle, end cells pale, conoid, smaller, 40-45 $\times 9$ $10 \mu \mathrm{m}$.

Material examined - India, Kerala, Thiruvananthapuram, Karakulam, Eanikara, on leaves of Strychnos nuxvomica L. (Strychnaceae), 26 January 2001, V.B. Hosagoudar HCIO 44154 (holotype), TBGT 520 (isotype); 30 December 2000, P.Y. Basanagowda TBGT 690, HCIO 44406; Karnataka, South Canara, Kukke Subramanya, 15 November 2003, V.B. Hosagoudar \& al HCIO 45748, TBGT 1497; TBGT 1822, HCIO 46059; TBGT 1824, HCIO 46061; TBGT 1827, HCIO 46064; Kerala, Kollam, Arippa, on leaves of Strychnos sp., 27 October 2006, V.B. Hosagoudar TBGT 4679.

This fungus was associated with the dark colonies of Meliola sp. However, when Meliola colonies matured, a whitish coating formed on the black colonies and it may be due to the production of enormous number of Questieriella conidia. The end cells of the conidia were much smaller and paler than the central two cells. Later, these two end cells wrinkle and disappear as the spore starts germinating.

This species differs from Schiffnerula spigeliae Hansf. known on Spigelia anthelmia from Sierra Leone in having larger falcate conidia (Hansford 1949, Sivanesan 1984).

Questieriella tephrosiae Hosag. \& Agarwal, Indian Phytopath. 55: 500, 2002. (Fig. 8)

Colonies epiphyllous, dense, up to $2 \mathrm{~mm}$ in diameter, rarely confluent. Hyphae straight to substraight, branching alternate to irregular at acute angles, loosely to closely reticulate, cells 19-24 × 4-6.5 $\mu \mathrm{m}$. Appressoria scattered, alternate to unilateral, globose, mammiform, broad based, 8 $10 \times 7-9 \mu \mathrm{m}$. Conidiogenous cells intercalary in the hyphae, scattered, cylindrical, pale brown, up to $12 \mu \mathrm{m}$ long and up to $2.5 \mu \mathrm{m}$ broad. Conidia solitary, fusiform, straight to slightly curved, 3septate, pale brown, 30-34 ×9-11.5 $\mu \mathrm{m}$.

Material examined - India, Kerala, Wayanad, Chembra Peak, on leaves of Tephrosia tinctoria Pers. (Fabaceae), 18 November 1999, C.K. Biju TBGT 398 (isotype), HCIO 43807 (holotype); HCIO 43448, TBGT 280.

Most of the conidia were germinated and formed colonies. The initials of ascomata and developed ascomata are similar to that of the 
Plant Pathology \& Quarantine

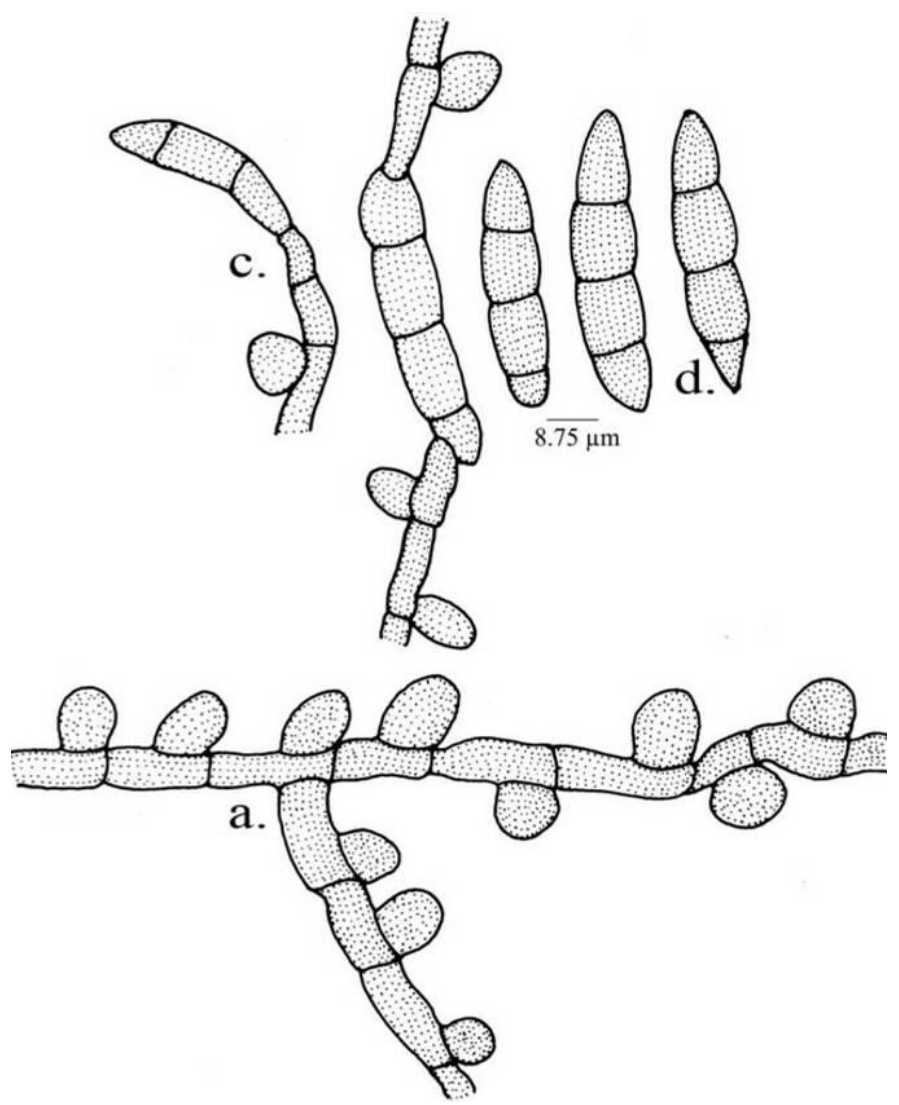

Fig. 6-Questieriella sarcococcae

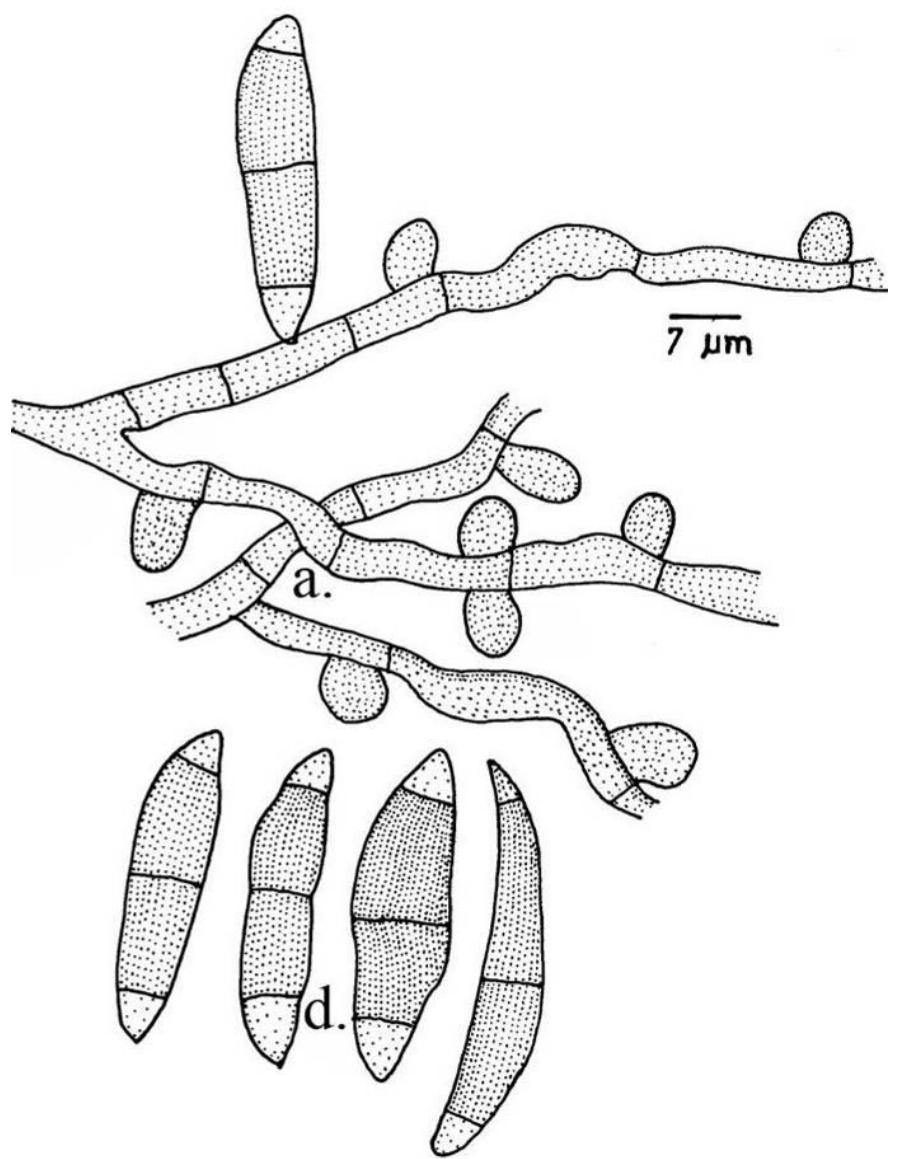

Fig. 7 - Questieriella strychni 


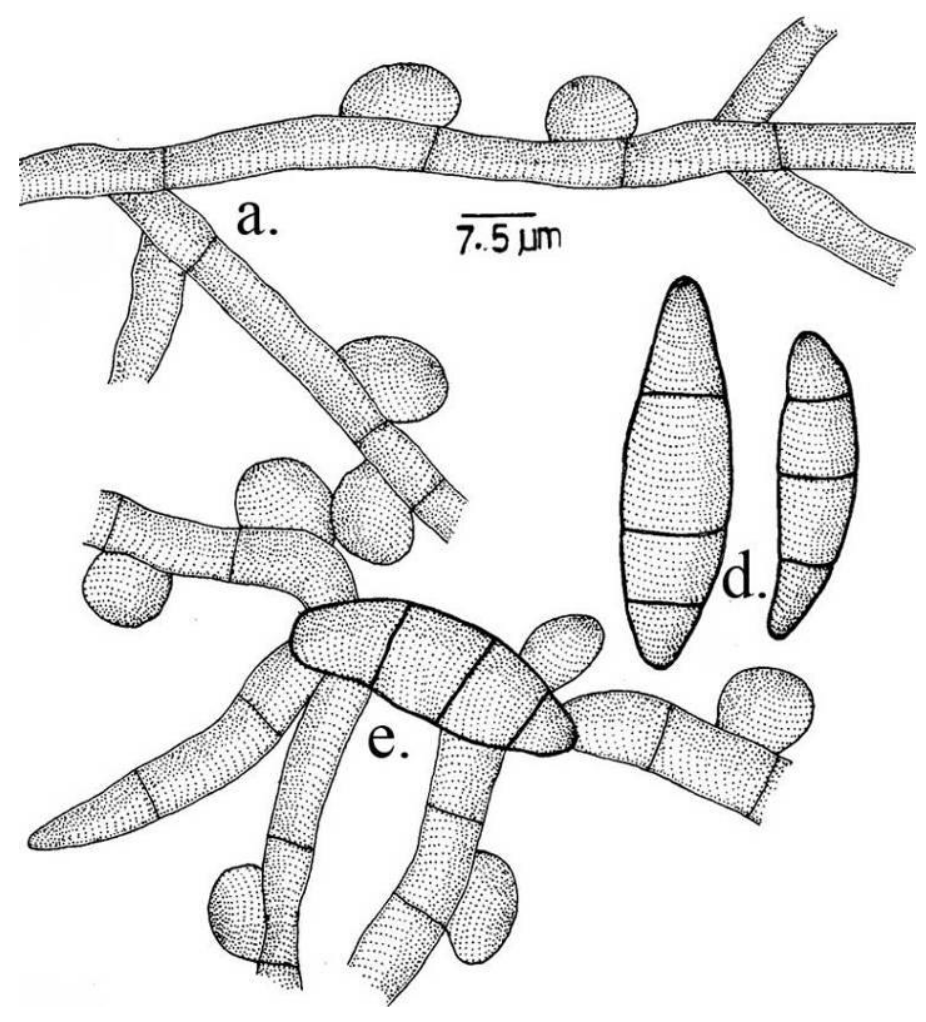

Fig. 8 - Questieriella tephrosiae

genus Schiffnerula but, ascomata did not reveal asci and ascospores. However, Schiffnerula cassiae Hansf., known on Cassia kirki from Africa does not have any anamorphs (Hansford 1949, Hughes 1987).

Questieriella toddaliae Hosag., Madhavan, Dhivaharan \& Sangeetha, Zoos Print J. 22(10): 2861, 2007. (Figs 9-10)

Colonies amphigenous, thin, up to $2 \mathrm{~mm}$ in diameter, confluent. Hyphae straight to substraight, branching opposite, alternate to irregular at acute to wide angles, loosely reticulate, cells 14-24 × 4-8 $\mu \mathrm{m}$. Appressoria alternate, scattered, unicellular, oval to globose, entire to slightly angular, 9-13 $\times 6-13 \mu \mathrm{m}$. Conidia pale brown, fusiform, curved, 3-septate, slightly constricted at the septa, distal cells attenuated, 24-37 × 11-18 $\mu \mathrm{m}$.

Material examined - India, Tamil Nadu, Kodaikanal, Mathikettan shola, on leaves of Toddalia asiatica (L.) Lam. (Rutaceae), G, Sangeetha HCIO 47675 (holotype), TBGT 2697 (isotype); Samikanal, on leaves of T. asicatica var. floribunda Gamble (Rutaceae), 15 April 2007, R. Nithyatharani TBGT 4430; Periya Kanal, 7 January 2010, R. Nithyatharani TBGT 4448.
Schiffnerula toddaliae Hansf. is known on this host from Uganda with Questieriella anamorph (Hansford 1941a). Clypeolella toddaliae Hansf. known on T. aculeata from Uganda has only teleomorphic state and has been made synonymous with $S$. toddaliae Hansf. (Hughes 1983, 1987, Hosagoudar 2003a, b). However, this collection appears to be the synanamorph of $S$. toddaliae but in absence of the teleomorph, it is preferred to place it in the assigned status.

Questieriella zanthoxyli Hosag., Jacob. \& Robin, Indian J. Sci. \& Techn. 2 (6): 4, 2009.

(Fig. 11)

Colonies epiphyllous, minute, up to 2 $\mathrm{mm}$ in diameter, confluent. Hyphae straight to substraight, slightly flexuous, branching opposite to alternate at acute angles, loosely reticulate, cells $9 \times 7 \mu \mathrm{m}$. Appressoria scattered, mammiform, entire to angular, 7-12 $\times 5-7 \mu \mathrm{m}$. Conidia numerous, borne directly from the hyphal cells, pale brown, straight to curved, 3septate, rarely constricted at the septa, 24-34 $\times$ 7-10 $\mu \mathrm{m}$.

Material examined - India, Meghalaya, Shillong, Lumshillong, on leaves of Zanthoxylum khasianum Hook. f. (Rutaceae), 18 January 


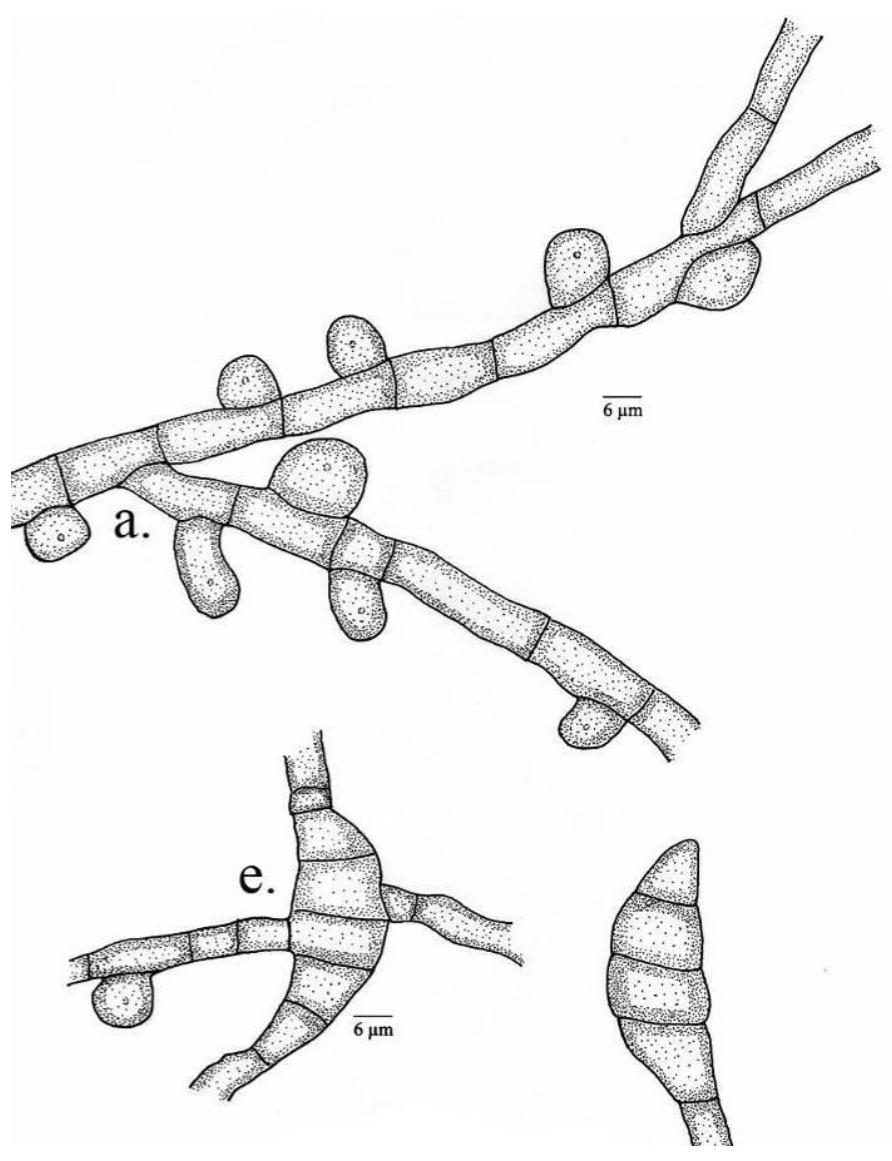

Fig. 9 - Questieriella toddaliae

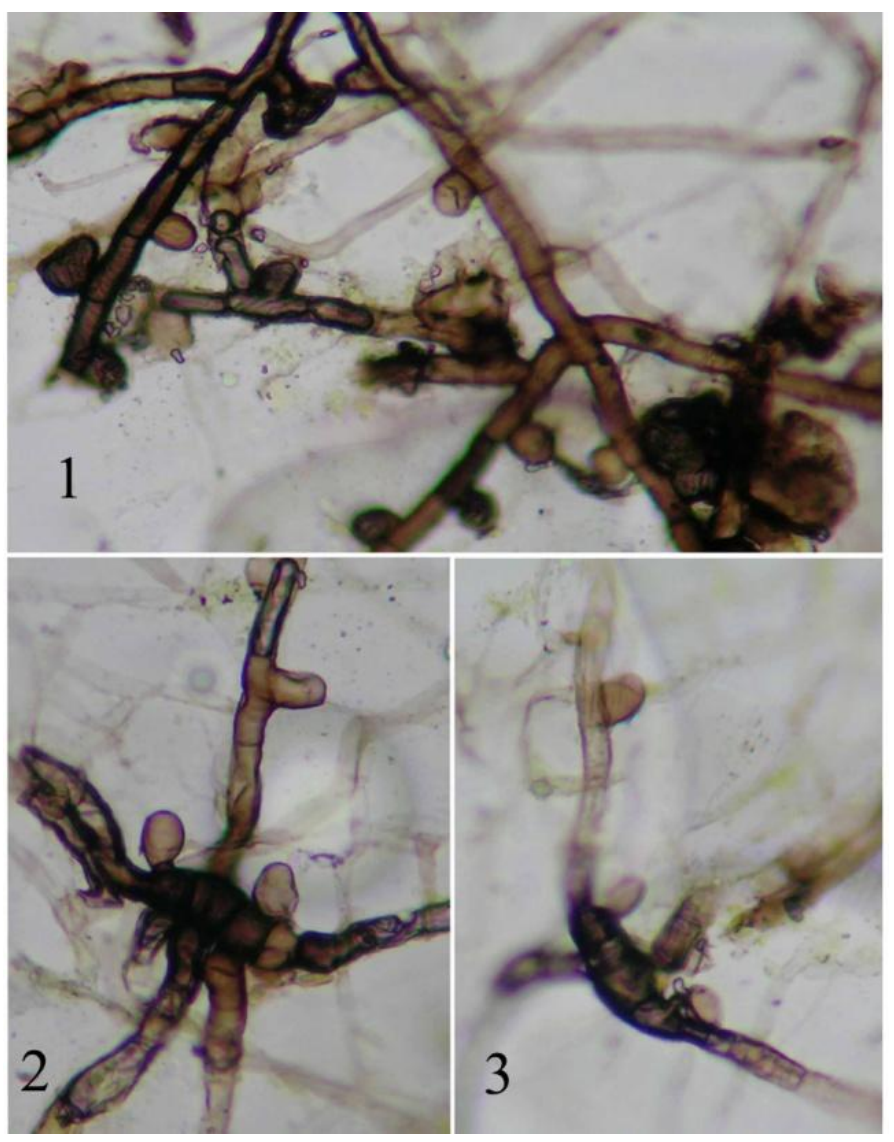

Fig. 10 - Questieriella toddaliae 


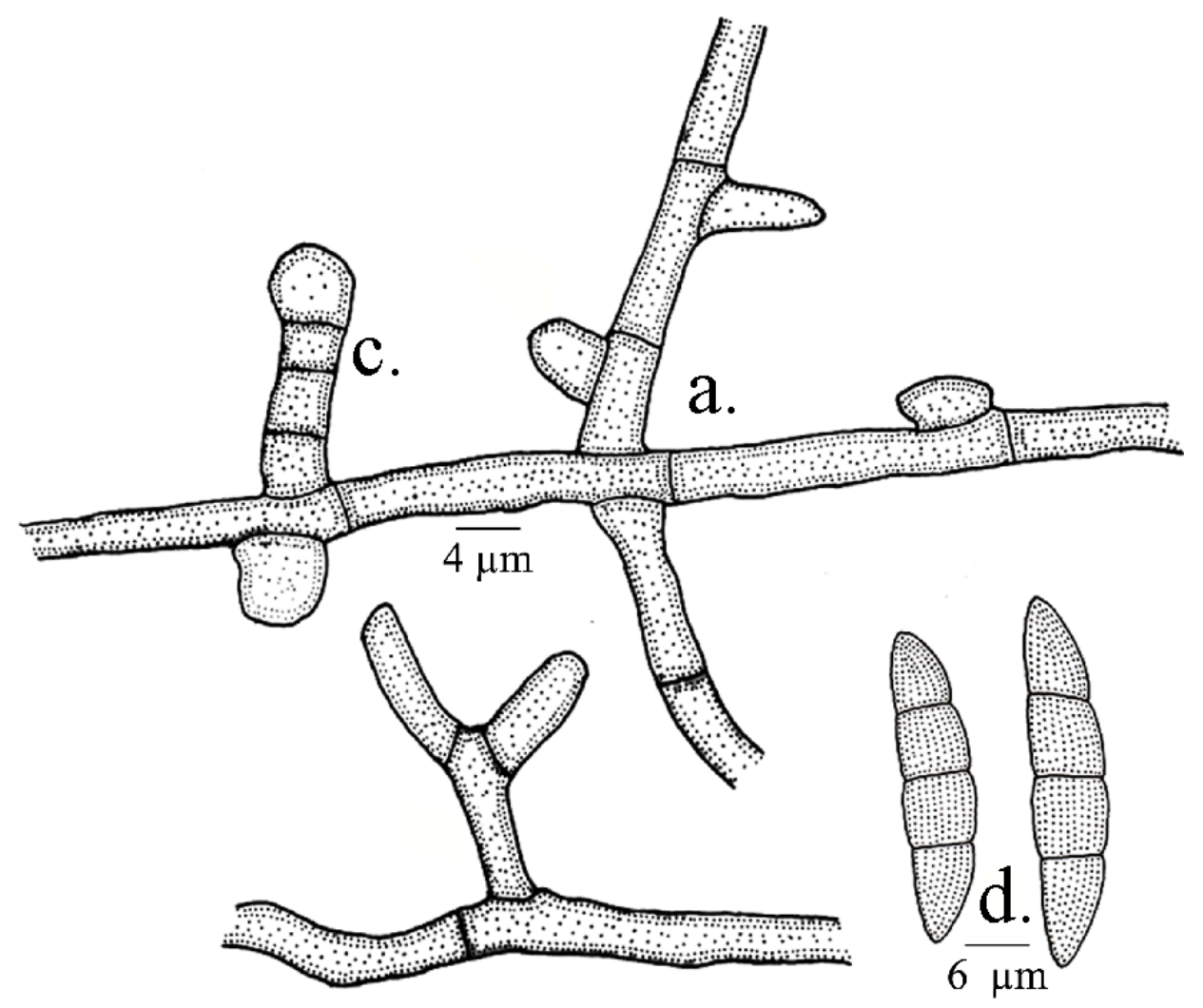

Fig. 11 - Questieriella zanthoxyli

2007, Jacob Thomas \& P.J. Robin HCIO 48070 (holotype), TBGT 2853 (isotype); Karnataka, Kodagu, Bhagamandala, on leaves of Zanthoxylum sp., November 25, 2008, Jagath Thimmaiah TBGT 5356.

Schiffnerulla toddaliae is known on Toddalia asiatica from Uganda, Sarcinella glycolsmidis Kamal \& Singh on Glycosmis pentaphylla and S. fumosa Sahni on Eagle marmelos from India are known. The present collection persists in its Questieriella form on a hitherto unrecorded host genus and it warrants its placement in an assigned species.

\section{The genus Sarcinella}

Sarcinella Sacc., Michelia 2: 31, 1880.

Colonies black. Hyphae superficial, branched, septate, appressoriate. Appressoria lateral, unicellular. Conidiophores macronematous, semi-macronematous, simple to branched. Conidiogenous cells monoblastic, integrated, terminal, intercalary, determinate. Conidia solitary, acrogenous or acropleurogenous, subspherical, sarciniform, dark brown to reddish brown, smooth, constricted at the septa.

Type - S. heterospora Sacc.

\section{Description of the species}

Sarcinella allophyli Hosag., J. Mycopathol. Res. 44: 20, 2006; Hosag. \& Riju, Indian J. Sci. \& Techn. 2(6): 7, 2009.

(Fig. 12)

Colonies amphigenous, mostly hypophyllous, dense, spreading, up to $3 \mathrm{~mm}$ in diameter. Hyphae straight to flexuous, pale brown, branching irregular at acute to wide angles, loosely reticulate, cells $17-24 \times 3-5 \mu \mathrm{m}$. Appressoria scattered, alternate, unilateral, rarely opposite, ovate to mostly globose, entire, $7-9 \times 6-11$ $\mu \mathrm{m}$. Conidiophores produced lateral to the hyphae, simple, branched, straight to flexuous, micronematous to semi-macronematous, 9-32 $\times$ 4-6 $\mu \mathrm{m}$. Conidiogenous cells terminal, intercalary, monoblastic, integrated, determinate, cylindrical. Sarciniform conidia solitary, dry, simple, subspherical to oval, 2-10-celled, brown to charcoal black, muriform, constricted at the septa, 24-32 $\mu \mathrm{m}$ in diameter, wall smooth.

Material examined - India, Karnataka, Coorg, Madikeri, Jodupal, on leaves of Allophylus cobbe (L.) Raensch. (Sapindaceae), 12 November 2003, V.B. Hosagoudar \& al. HCIO 45814 (holotype), TBGT 1564 (isotype); 


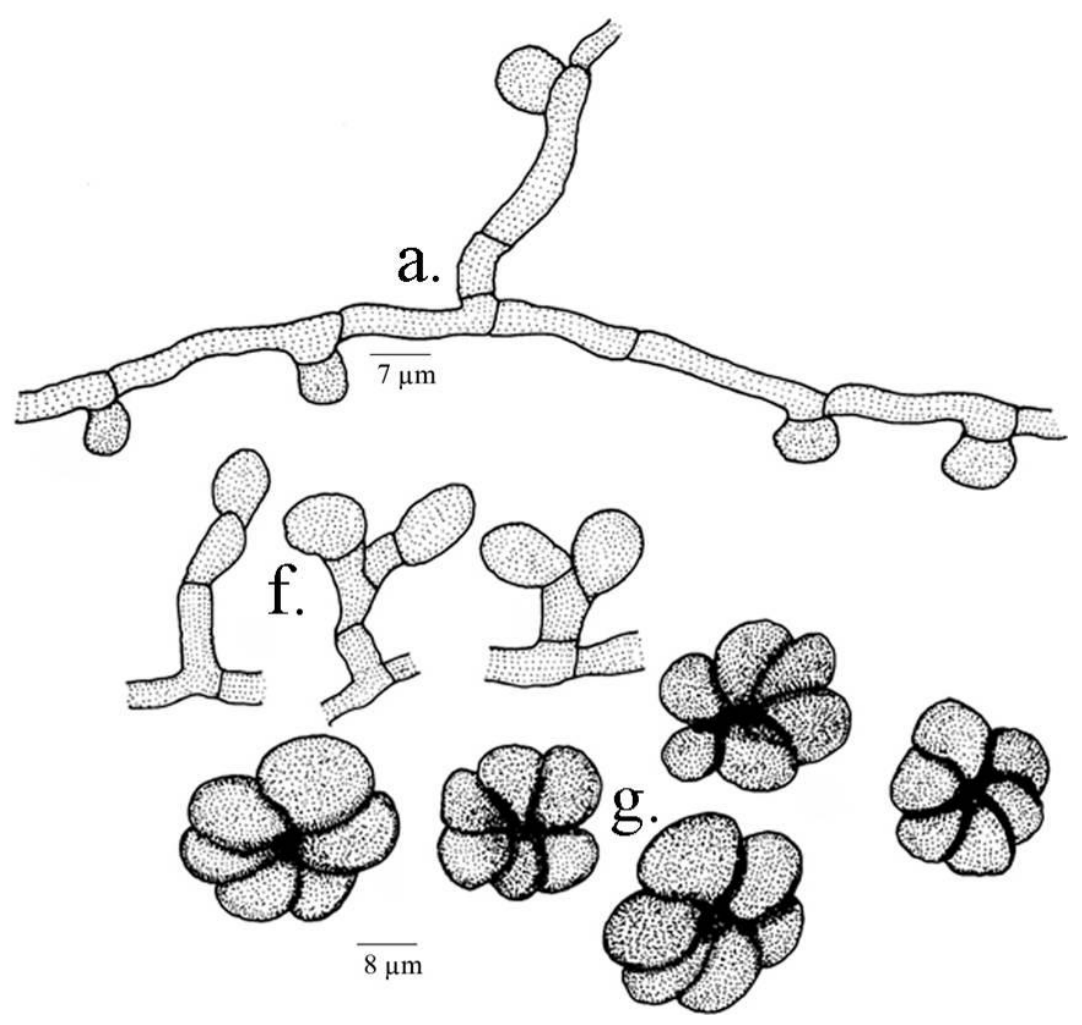

Fig. 12 - Sarcinella allophyli

Kerala, Palghat Silent valley, Sairandhri, 13 December 2003, V.B. Hosagoudar TBGT 2382, HCIO 47344; Wayanad, Padinharathara, $16^{\text {th }}$ mile, on leaves of Allophyllus sp., 9 November 2007, M.C. Riju HCIO 48179, TBGT 2915; Wayanad, 11 November 2007, A. Chandraprabha HCIO 49908, TBGT 4060.

Schiffnerula allophyli Hansf. is known on Allophylus sp. from Uganda (Hansford 1946, Hosagoudar 2003a,b) and the present fungus is only with the Sarcinella state. Hence, it has been accommodated in the form genus.

Sarcinella asiatica Kamal, Rai \& MorganJones, Mycotaxon 20: 589, 1984.

Infection spots amphigenous, almost circular and small at first, soon becoming large and coalescing with age to cover the whole leaf. Colonies spreading extensively, powdery, black. Mycelium superficial. Hyphae pale brown to olivaceous, repent, branched and forming a loose but well developed network on the leaf surface, septate, smooth, thick walled, 5-7 $\mu \mathrm{m}$ wide. Appressoria abundant, hemispherical to subglobose, pale brown, mostly unilateral, 7-15 × 7-11 $\mu \mathrm{m}$ Conidiophores micronematous, arising laterally from the hyhae, short, simple, straight, smooth, pale brown, pa- ler towards the apex. Conidiogenous cells monoblasic, integrated, terminal, cylindrical, determinate, conidia solitary, dry simple, smooth, suglobose to irregularly sarciniform, muriform, septa usually more or less cruciately arranged, dark brown to black, strongly constricted at the septa, thick walled, appearing 48-lobed, 25-36 × 14-29 $\mu \mathrm{m}$.

India, Uttar Pradesh, North Gonda Forest division, Tulsipur, on unidentified living leaves, November 1979, A.N. Rai IMI 246387 (holotype), GPU (KR 361).

Since this species is on an unknown host, its status is doubtful.

Sarcinella atalantiae V.B. Hosagoudar et M.C. Riju, sp. nov.

(Fig. 13)

Coloniae amphigenae, plerumque hypophyllae, tenues, velutinae, ad $4 \mathrm{~mm}$ diameter. Hyphae rectae vel subrectae, opposite vel alternatim acuteque vel laxe ramosae, laxe reticulatae, cellulae 19-24 × 2-3 $\mu \mathrm{m}$. Appressoria alternata, unilateralis, globosa, mammiformes, $7-10 \times 5-7 \mu \mathrm{m}$. Conidiophorae micronematae, mononematae, unicellularis, uni vel biseptatae, $10-19 \times 5-7 \mu \mathrm{m}$; cellulae conidiogenae monoblasticae, cylindraceae. Conidia solitaria, simplices, sarciniformes, nigra, 


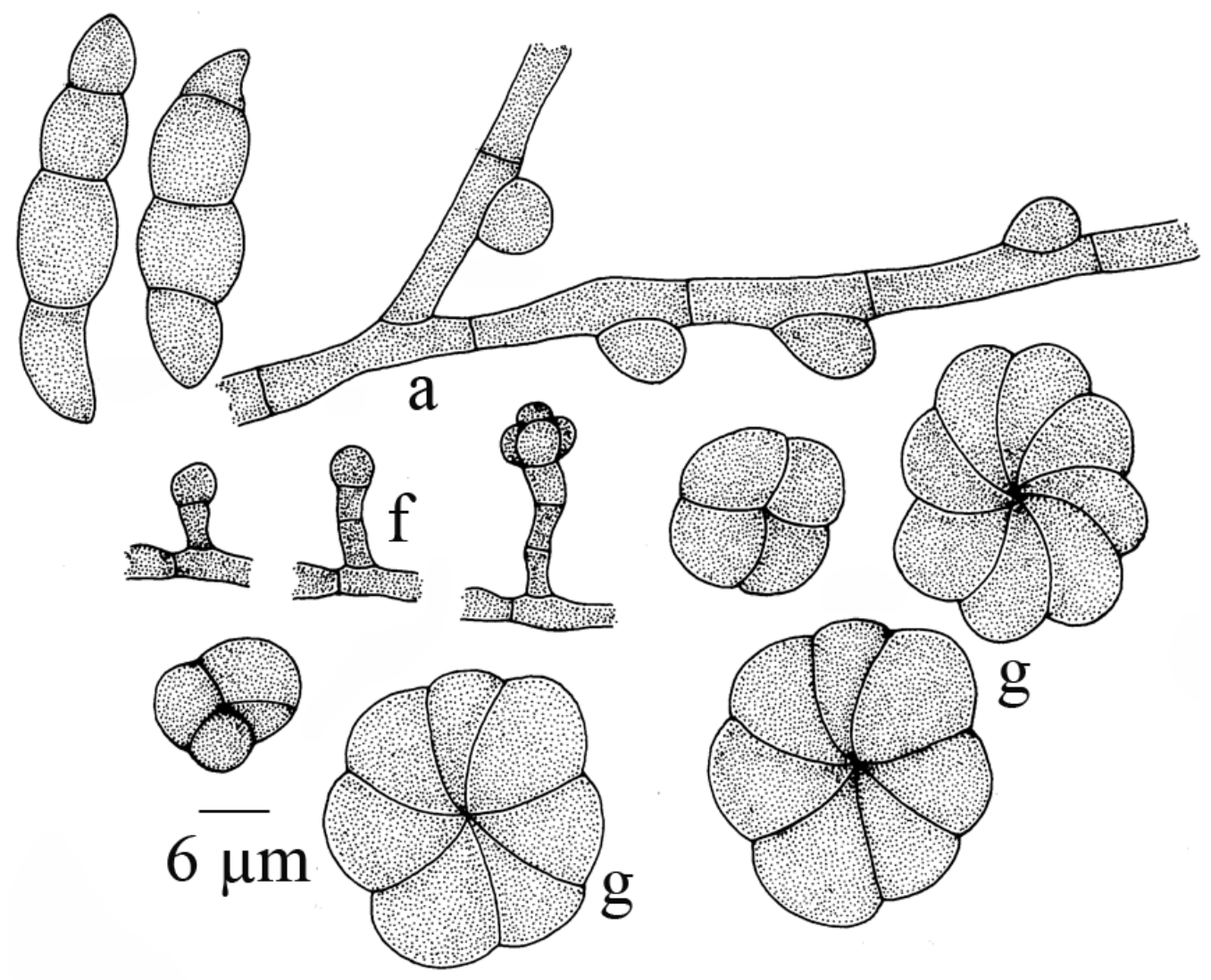

Fig. 13 - Sarcinella atalantiae

septata, leniter constrictus ad septata, ad octo cellularis, ad $52 \mu \mathrm{m}$ diameter. Conidia Questeriella dispersa in coloniis, falcata, pallide vel pallide brunnea, tri septatis, leniter constrictus ad septata, 35-50 × 12-15 $\mu \mathrm{m}$.

Colonies amphigenous, mostly hypophyllous, thin, velvety, up to $4 \mathrm{~mm}$ in diameter. Hyphae straight to substraight, branching opposite to alternate at acute to wide angles, loosely reticulate, cells $19-24 \times 2-3 \mu \mathrm{m}$. Appressoria alternate, unilateral, globose, mammiform, 7$10 \times 5-7 \mu \mathrm{m}$. Conidiophores micronematous, mononematous, unicellular, 1-2-septate, 10-19 $\times$ 5-7 $\mu \mathrm{m}$; conidiogenous cells monoblastic, cylindrical. Conidia solitary, simple, sarciniform, dark brown, septate, slightly constricted at the septum, up to 8 cells, up to $52 \mu \mathrm{m}$ in diameter. Questeriella conidia scattered in the colonies, falcate, pale to pale brown, three septate, slightly constricted at the septa, 35-50 $\times 12-15 \mu \mathrm{m}$.

Material examined - India, Kerala, Kottayam, Ponthanpuzha Researve Forest, on leaves of Atalantia sp. (Rutaceae), 20 August 2008, P.J. Robin TBGT 4974 (holotype). Part of the collection has been deposited in HCIO, New Delhi.

This species diffiers from Sarcinella limoniae Hosag. et al. in having larger Sarcinella conidia.

Sarcinella bignoniacearum Chandra, Srivast. \& Chaudhary, Indian Phytopath. 44: 302, 1991.

Colonies amphigenous, usually epiphyllous, spreading extensively, effuse, dense, powdery, black, irregularly growing and usually covering most of the leaf surface, coalescing with age; mycelium of hyphae superficial, brown, thick walled, branched oppositely and occasionally irregularly, with cells $14-20 \times 6$ $10 \mu \mathrm{m}$. Appressoria alternate to unilateral, hemispherical some times subglobose, pale brown, $8-18 \times 8-12 \mu \mathrm{m}$. Conidiophores micronematous, small, unbranched, straight, rarely flexuous, light brown, arising usually laterally on the hyphae, simple, smooth walled, paler towards the apex; conidiogenous cells monoblastic, integrated, terminal determinate, cylindrical; conidia solitary, acrogenous, dry, subspherical, muriform, smooth, dark brown to black, deeply constricted at the septa, septa 
usually cruciately arranged, appearing usually 4-8-lobate in surface view, $21-42 \times 17-32 \mu \mathrm{m}$.

India, Uttar Pradesh, Nainital, on leaves of Oroxylum indicum Vent. (Bignoniaceae), date of collection not known, B.K. Gupta KB 217, IMI 282831 (holotype).

Sarcinella cassiae Butler ex Munjal \& Kapoor, Indian Phytopath. 26: 91, 1963 Sarcinella cassiae Butler, in herb.

Colonies foliicolous, often pods are completely covered, black. Hyphae loosely reticulate, pale to light brown, $12-20 \times 4-5 \mu \mathrm{m}$. Appressoria unilateral to alternate, concolourous, hemispherical, entire, $8-10 \times 6-8 \mu \mathrm{m}$. Sarcinella conidia borne on a short conidiophores, dark brown to opaque, almost rounded, muriform, 36-44 × 30-36 $\mu \mathrm{m}$. Questieriella conidia falcate, fusiform to elliptic, 3-septate, middle cells pale, end cells hyaline, 36-40 $\times$ $10-12 \mu \mathrm{m}$.

India, Karnataka, Belgaum, on leaves of Cassia tora L. (Caesalpiniaceae), 24 April 1903, E.J. Butler HCIO 12529; C. occidentalis L., Kumaon, Bhimtal, 19 October 1959, J.N. Kapoor HCIO 27028.

Sarcinella cassiae-fistulae Hosag. \& Shajivaz, Zoos' Print J. 17: 947, 2002.

(Fig. 14)

Colonies hypophyllous, thin, spreading, up to $5 \mathrm{~mm}$ in diameter. Hyphae pale brown, form a net throughout, cells $9-13 \times 3-4 \mu \mathrm{m}$. Appressoria not numerous, unilateral to rarely alternate, mammiform, broad based, entire, 6-7 $\mu \mathrm{m}$ in diameter. Conidiophores borne lateral to the hyphae, become erect, mostly unicellular, rarely a septa is formed, gibbous at the base, micronematous, mononematous, simple, straight, $14-16 \times 4-7 \mu \mathrm{m}$. Conidiogenous cells terminal, integrated, monoblastic, determinate, cylindrical. Conidia, solitary, simple, acrogenous, spherical to subspherical, 4-12-celled, sarciniform, slightly to deeply constricted at the septa, charcoal black, 19-24 $\mu \mathrm{m}$ in diameter, wall smooth.

Material examined - India, Kerala, Anchal, Kollam, on leaves of Cassia fistula L. (Caesalpiniaceae), 29 November 2001, M.M. Shajivaz HCIO 44407(holotype), TBGT 597 (isotype).

Sarcinella cassiae Butler in Munjal \& Kapoor (1963) is known on Cassia tora and $C$. occidentalis from Belgaum, Karnataka and Bhimtal, Kumaon. However, S. cassiae-fistulae differs from it in having thin hypophyllous colonies, having only sarciniform and smaller conidia.

Sarcinella castanopsidis Hosag., Jacob \& Robin, Indian J. Sci. \& Techn. 2(6): 5, 2009.

(Fig. 15)

Colonies epiphyllous, thin, spreading, up to $2 \mathrm{~mm}$ in diameter. Hyphae pale brown, straight to substraight, branching alternate to opposite at acute to wide angles, loosely to closely reticulate, forming a net, cells $22-31 \times$ 5-7 $\mu \mathrm{m}$. Appressoria alternate to unilateral, straight, ovate, globose, unicellular, broad based, margin entire, sessile, 7-10 × 12-14 $\mu \mathrm{m}$. Conidiophores borne lateral to the hyphae, become erect, unicellular, gibbous at the base, micronematous, mononematous, simple, straight, 4-10 × 5-7 $\mu \mathrm{m}$; conidiogenous cells terminal, integrated, monoblastic, cylindrical; conidia simple, solitary, acrogenous, spherical to subspherical, 8-15 celled, sarciniform, slightly to deeply constricted at the septa, charcoal black, $31-46 \mu \mathrm{m}$ in diameter, wall smooth.

Material examined - India, Meghalaya, Shillong, Lumshillong, on leaves of Castanopsis armata Spach. (Fagaceae), 18 January 2007, Jacob Thomas \& P.J. Robin TBGT 2899 (holotype), HCIO 48163 (isotype).

Sarcinella cipadessae Hosag. \& Jacob Thomas, Indian Sci. \& Techn. 2(6): 26, 2009.

(Figs 16-17)

Colonies epiphyllous, dense, up to $2 \mathrm{~mm}$ in diameter, confluent. Hyphae pale brown, substraight to flexuous, branching opposite to irregular at acute to wide angles, loosely to closely reticulate, cells $19-29 \times 4-7 \mu \mathrm{m}$. Appressoria alternate, unicellular, subglobose to ovate, mammiform, entire, 7-12 × 9-12 $\mu \mathrm{m}$. Conidiophores macronematous, mononematous, simple, straight, arise laterally from the hyphae, smooth, 7-12 × 4-7 $\mu \mathrm{m}$; conidiogenous cells integrated, mostly terminal, monoblastic, determinate, cylindrical; conidia simple, solitary, dry, acrogenous, globose to oval, smooth, brown to dark, constricted at the septa, 4-6 celled, cells circinately arranged, $26-31 \times 21-36 \mu \mathrm{m}$. Conidia of Questieriella were scattered in the 


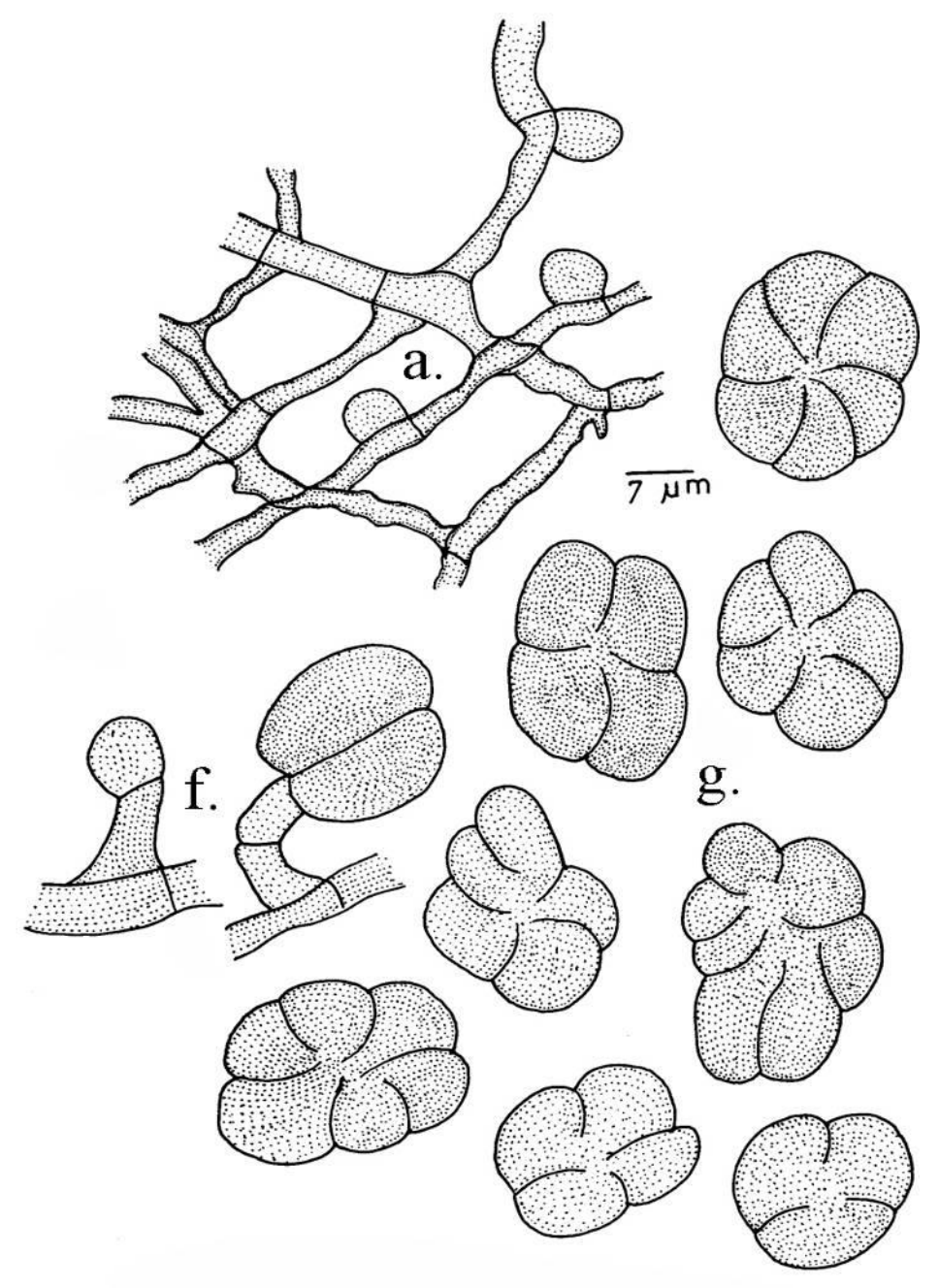

Fig. 14 - Sarcinella cassiae-fistulae

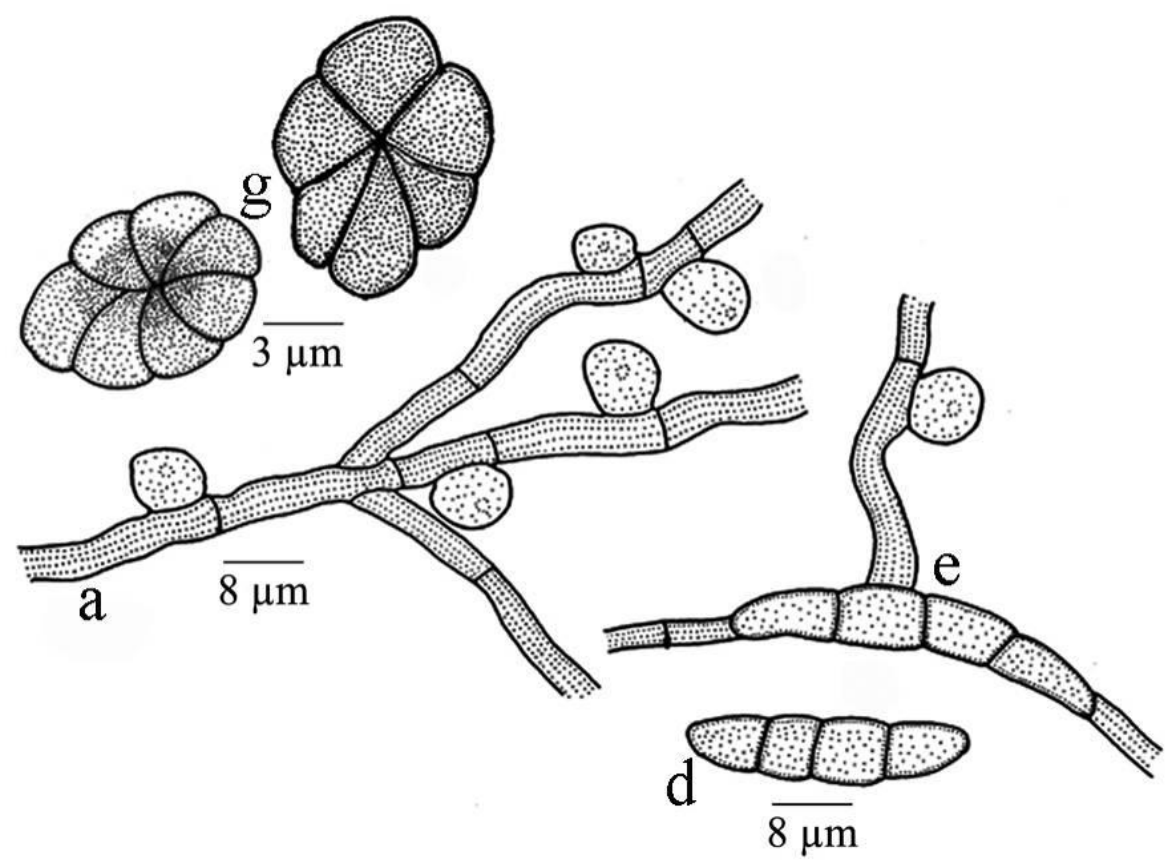

Fig. 15 - Sarcinella castanopsidis 

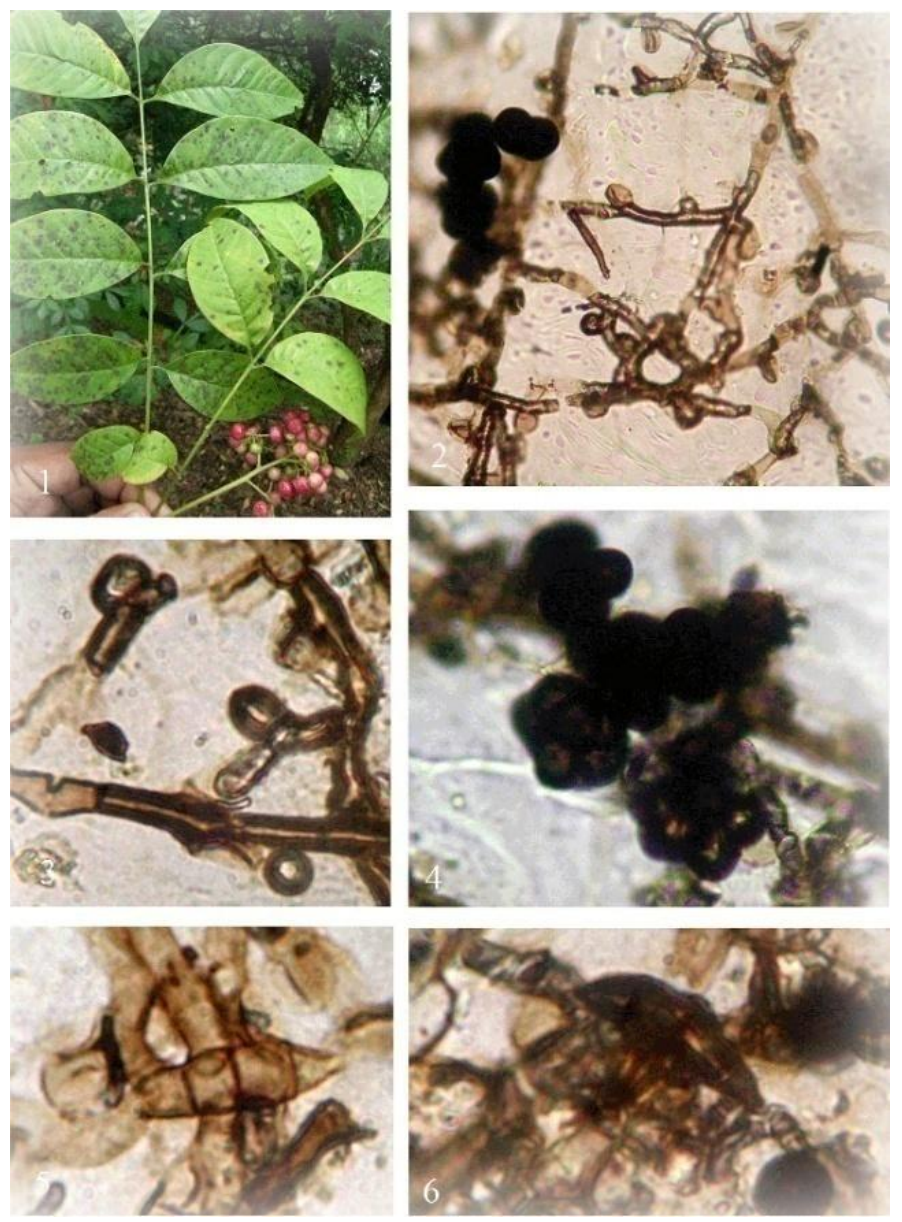

Fig. 16 - Sarcinella cipadessae, 1 Infected leaves, 2 Mycelium, 3 Appressoriate mycelium, 4 Conidia of Sarcinella, 5-6 Germinating conidia of Questieriella.

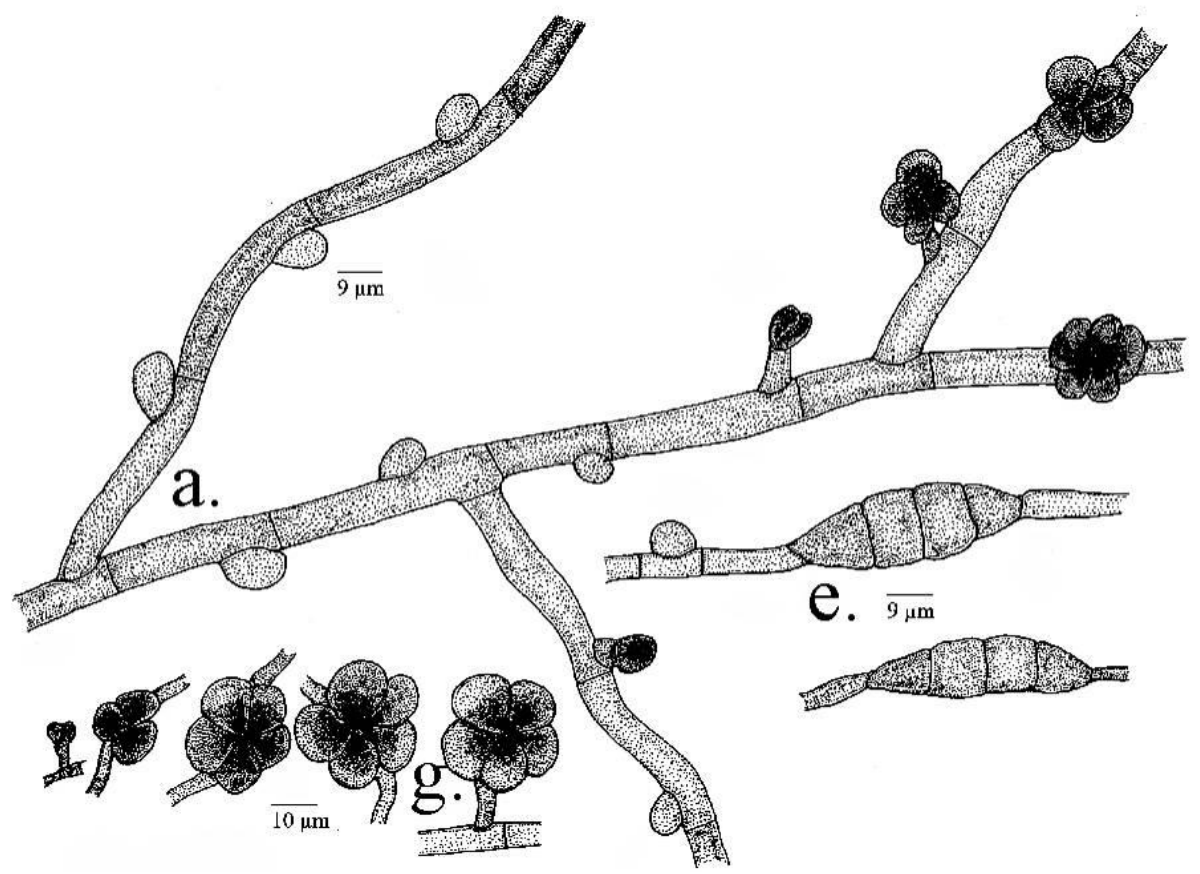

Fig. 17- Sarcinella cipadessae 
colonies, pale brown, slightly falcate, 3septate, end cells attenuated, light brown, 31-34 × 7-10 $\mu \mathrm{m}$, wall smooth.

Material examined - India, Kerala, Thiruvananthapuram, Peppara Wildlife Sanctuary, on leaves of Cipadessa baccifera (Roth.) Miq. (Meliaceae), 18 November 2007, Jacob Thomas and Vimal Kumar HCIO 48249 (holotype), TBGT 2988 (isotype).

Sarcinella azadirachtae Meenu et al. is known on Azadirachta indica from Nepal (Meenu et al. 1994). However, this taxon is segregated based on the host specificity.

Sarcinella colebrookiana Kamal \& Singh, Sydowia 33: 152, 1980.

Colonies amphigenous, usually epiphyllous, effuse, dense, black, irregularly growing and usually covering most of the leaf surface, coalescing with age; mycelium superficial, light brown, composed of network of laterally to rarely oppositely branched, septate, thick walled mycelium containing cells $10-15 \times 4-7$ $\mu \mathrm{m}$. Appressoria mostly unilateral, hemispherical, sometimes subglobose, light brown, 7-9 $\mu \mathrm{m}$ in diameter. Conidiophores macronematous, mononematous, simple, small, unbranched, straight, rarely flexuous, light brown, arising usually laterally on the hyphae, simple, smooth walled, slightly paler and $7-9 \mu \mathrm{m}$ thick towards the apex. Conidiogenous cells monoblastic, integrated, terminal, determinate, cylindrical; conidia solitary, acrogenous, subspherical, smooth, dark brown, muriform, strongly constricted at the septa, sarciniform septa usually cruciately arranged, appearing up to 11lobed in surface view, 30-50 $\mu \mathrm{m}$ diameter.

India, Uttar Pradesh, Gorakhpur, on leaves of Colebrookia oppositifolia Smith (Lamiacee), August 1976, R.P. Singh 205, IMI 210836. (holotype)

Sarcinella dalbergiae Hosag. \& Agarwal, Indian Phytopath. 55: 501, $2002 . \quad$ (Fig. 18)

Colonies epiphyllous, subdense, up to 2 $\mathrm{mm}$ in diameter, confluent. Hyphae flexuous to crooked, branching irregular at acute angles, loosely reticulate and form loose mycelial net, cells $12-21 \times 3-5 \mu \mathrm{m}$. Appressoria alternate, very few opposite, unicellular, globose, broad based, entire, 9-12 $\mu \mathrm{m}$ broad and 6-7 $\mu \mathrm{m}$ high. Conidiophores micronematous, mononematous sim- ple, straight, cylindrical, $18-22 \times 11-12 \mu \mathrm{m}$. Conidiogenous cells integrated, terminal, monoblastic, determinate, cylindrical, conidia solitary, simple, acrogenous, spherical to subspherical, 4-12 celled, sarciniform, deeply constricted at the septa, charcoal black, $19-30 \mu \mathrm{m}$ in diameter, wall smooth.

Material examined - India, Kerala, Wayanad, Banasuran mala, on leaves of Dalbergia sp. (Fabaceae), 19 April, 1999, C.K. Biju HCIO 43806 (holotype), TBGT 391(isotype).

Sarcinella cassiae Butler is known on Cassia tora (Ceasalpiniaceae). Loosely net forming hyphae and few opposite, globose and larger apressoria distinguishes the present anamorph from it.

\section{Sarcinella glycosmidis Kamal \& Singh,} Sydowia 33: 154, 1980.

Colonies amphigenous, mostly epiphyllous, subdense to dense, light brown to black, small, scattered, separate, sometimes present almost on the entire leaf blade and appearing as black spots; mycelium superficial, composed of a network of branched, septate, light brown, thick walled hyphae which are branched usually oppositely and occasionally irregularly and contain cells measuring $4-8 \mu \mathrm{m}$ in width. Appressoria alternate to unilateral, hemispherical, occasionally subglobose, light brown, 7-9 $\mu \mathrm{m}$ in diameter. Conidiophores micronematous, small, unbranched, straight, rarely flexuous, light brown, arising usually on the hyphae, simple, smooth walled, slightly paler towards the apex, 5-8 $\mu \mathrm{m}$ thick; conidiogenous cells monoblastic, terminal, determinate, cylindrical; conidia solitary, acrogenous, subspherical, smooth, dark brown, muriform, deeply constricted at the septa, sarciniform, septa usually cruciately arranged, appearing usually 4-7 lobate in surface view, 20-34 $\mu \mathrm{m}$ in diameter.

India, Uttar Pradesh, Gorakhpur, on living leaves of Glycosmis pentaphylla Correa (Rutaceae), September 1976, R.P. Singh 267, IMI 212573 (holotype).

Sarcinella gmelinae Hosag., Archana, Harish, Riju \& Agarwal, Indian Phytopath. 61: 247, 2008.

(Fig. 19)

Colonies amphigenous, mostly epiphyllous, dense, crustose, up to $2 \mathrm{~mm}$ in diameter, confluent. Hyphae pale brown, substraight to 
Plant Pathology \& Quarantine

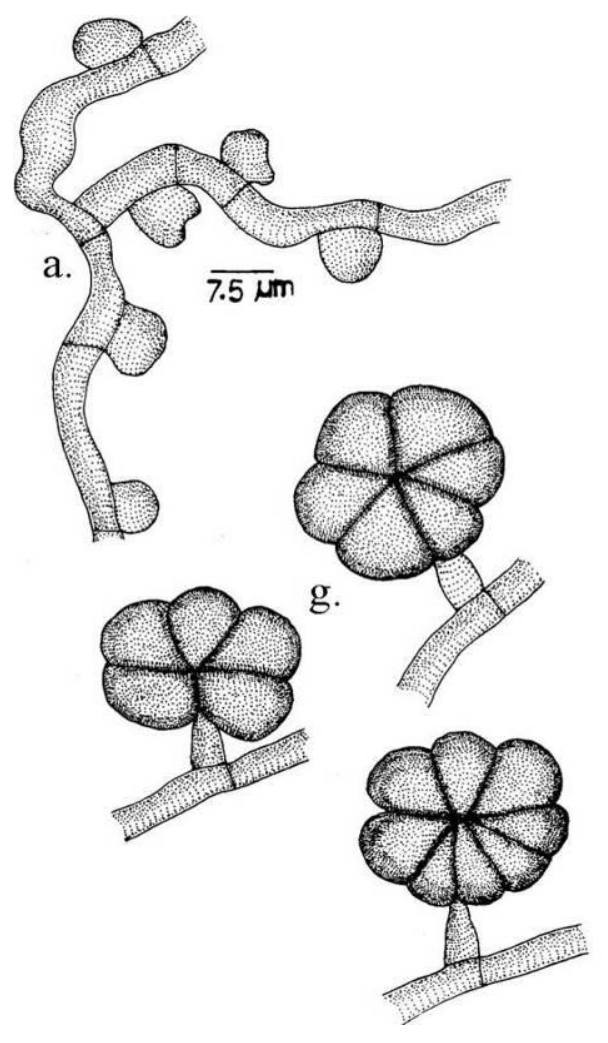

Fig. 18 - Sarcinella dalbergiae

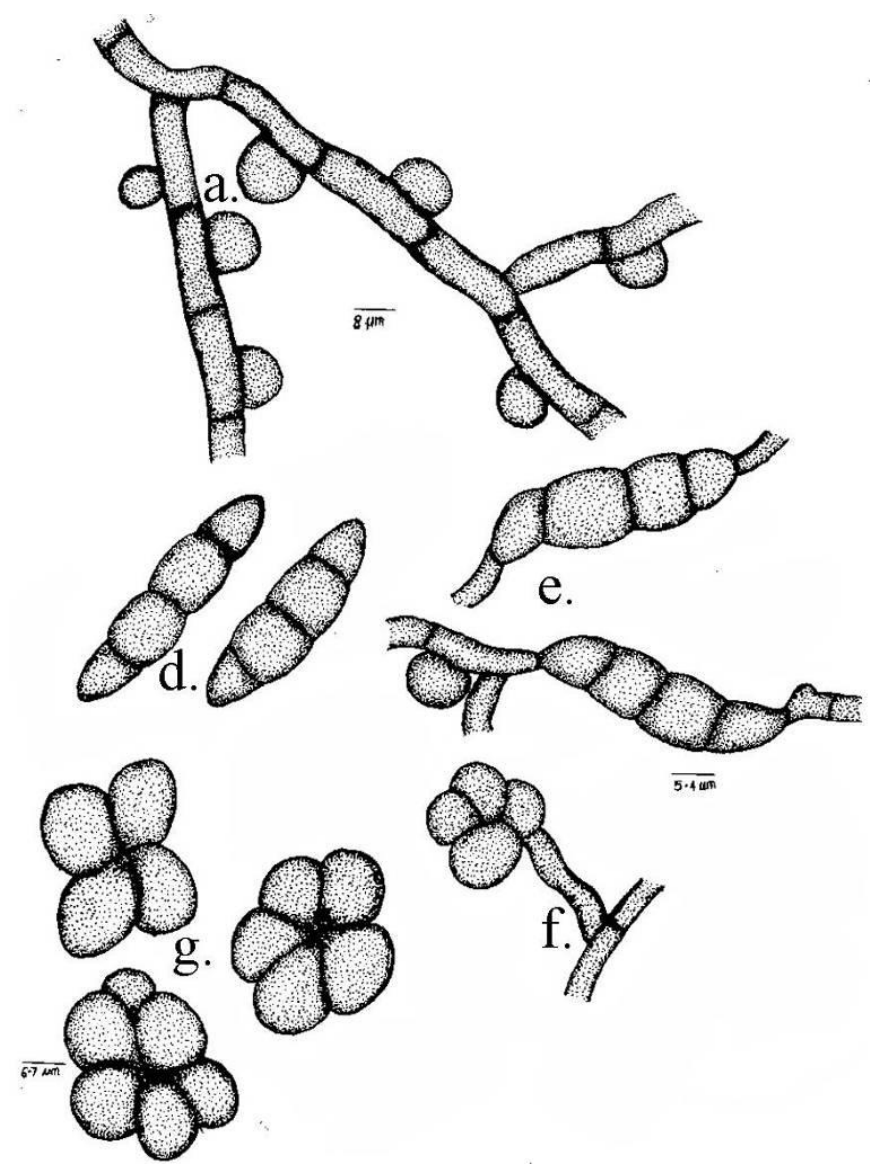

Fig. 19 - Sarcinella gmelinae 
undulate, branching mostly alternate, rarely opposite at acute angles, loosely to closely reticulate, cells 15-25 × 4-6 $\mu \mathrm{m}$. Appressoria alternate to unilateral, globose to subglobose, ovate, mammiform, entire, 6-11 $\times 7-9 \mu \mathrm{m}$. Conidiophores macronematous, mononematous, simple, straight to slightly curved, light brown, arise laterally from the hyphae, smooth, 7-15 $\times$ 5-10 $\mu \mathrm{m}$; conidiogenous cells integrated, terminal, monoblastic, determinate, cylindrical to ovate. Conidia simple, dry, solitary, acrogenous, globose to ovate, smooth, carbonaceous black, 4-8-celled, sarciniform, constricted at the septa, $16-31 \times 15-25 \mu \mathrm{m}$.

Material examined - India, Kerala, Thirissur, Vazhachal, on leaves of Gmelina arborea L. (Verbenaceae), 21 August 2007, M. Harish \& Jacob Thomas HCIO 48132 (holotype), TBGT 2965 (isotype).

These colonies were intermixed with $\mathrm{Me}$ liola clerodendricola var. micromera.

Sarcinella gorakhpurensis Kamal \& Singh, Sydowia 33: 155, 1980; Hughes, Pleomorphy in some hyphopodiate fungi, p.110, 1987. Sarcinella diospyri Rajak \& Soni, Indian J. Mycol. Plant. Pathol. 11: 89, 1981.

Colonies amphigenous. Mycelium straight to substraight, opposite to irregularly branched, loosely reticulate, cells 6-8 $\mu \mathrm{m}$ wide. Appressoria hemispherical, often subglobose, mostly unilateral, occasionally alternate, light brown, 8-14 × 8-10 $\mu \mathrm{m}$. Sarcinella conidiophores small, micronematous, straight to curved, unbranched, light brown, paler at apex, smooth, arising usually laterally on the hyphae, 10-12 × 5-7 $\mu \mathrm{m}$; conidia dark brown to black, 4-9-celled, constricted at the septa, 22-32 $\mu \mathrm{m}$ in diameter, wall smooth. Questieriella conidia directly borne from the mycelial cells, 3-septate, falcate, light brown, middle cells darker than the terminal cells, both ends tapering and pointed, attachment scar seen at the basal end, 25-44 ×9-12 $\mu \mathrm{m}$.

India, on leaves of Diospyros melanoxylon Roxb. (Ebenaceae), Amarakantak forest, Jabalpur, Madhya Pradesh, December 1977, K.K. Soni IMI 224097; Madhaulia range, Gorakhpur, Uttar Pradesh, August 1976, R.P. Singh 211, IMI 210842.
Sarcinella gymnosporiae Subhedar \& Rao ex Hosag., Zoos Print J. 17: 837, 2002. Sarcinella gymnosporiae Subhedar \& Rao, Biovigyanam 1: 194, 1975 (nom. invalid.).

(Fig. 20)

Colonies amphigenous, mostly epiphyllous, subdense, up to $1 \mathrm{~mm}$ in diameter, confluent. Hyphae flexuous, branching irregular at acute to wide angles, loosely to closely reticulate and form a loose net of mycelia, cells 12 $20 \times 3-5 \mu \mathrm{m}$. Appressoria mostly globose, often ovate, entire, 6-8 $\times 8-12 \mu \mathrm{m}$. Questieriella conidia very few, germinating, falcate, pale brown, 3-septate, tapering towards both ends, acute, $28-30 \times 8-10 \mu \mathrm{m}$. Sarcinella conidia many; conidiophores macronematous, entire to 1-septate, simple, pale brown; conidiogenous cells monoblastic, integrated, terminal, determinate; conidia solitary, subspherical, sarciniform, 4-8 celled, dark-brown, constricted at the septa, 17-24 × 14-28 $\mu \mathrm{m}$, wall smooth.

Material examined - India, Maharashtra, Pune, Simhagad, on leaves of Gymnosporia rothiana (Walp.) Lawson (Celastraceae), 7 November 1973, A.W. Subhedar AMH 2741.

Subhedar \& Rao (1975) proposed this new species without description.

Sarcinella hippocrateae Srivastava, Chandra \& Gupta, Vegetos 3: 78, 1990.

Colonies epiphyllous, thin, up to $2 \mathrm{~mm}$ in diameter. Hyphae straight to substraight, branching irregular at acute to wide angles, loosely reticulate, cells $12-20 \times 4-6 \mu \mathrm{m}$. Appressoria scattered, alternate to unilateral, globose to slightly ovate, entire, concolourous to hyphae, 9-11 $\times 8-9 \mu \mathrm{m}$. Conidiophores lateral to the hyphae, entire to 1-septate, concolourous, micronematous to rarely semi-macronematous, simple, straight, $22-27 \times 4-5 \mu \mathrm{m}$. Conidiogenous cells terminal, integrated, determinate, cylindrical. Conidia solitary, dry, acrogenous, simple, subspherical to globose, sarciniform, dark brown, smooth, septate, constricted at the septa, 6-8-celled, 22-26 $\mu \mathrm{m}$ in diameter.

Holotype - India, Uttar Pradesh, on leaves of Hippocratea arborea (Hippocrataceae), January 1986, Satish Chandra GPU no. KC 78 (isotype); IMI 302799 (holotype).

Material examined - India, Karnataka, South Canara, Kukke Subramanya, on leaves 
Plant Pathology \& Quarantine

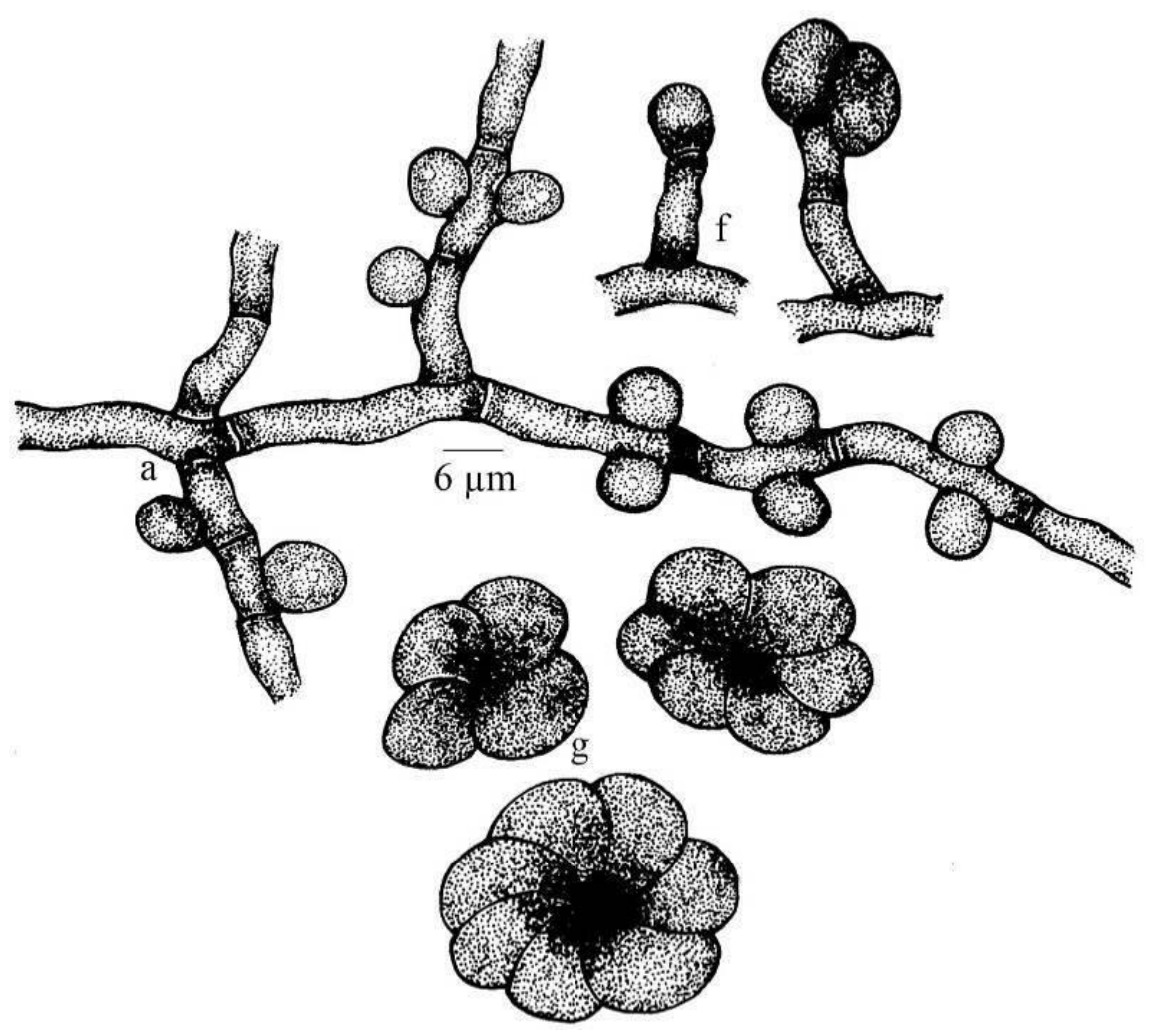

Fig. 20 - Sarcinella gymnosporiae

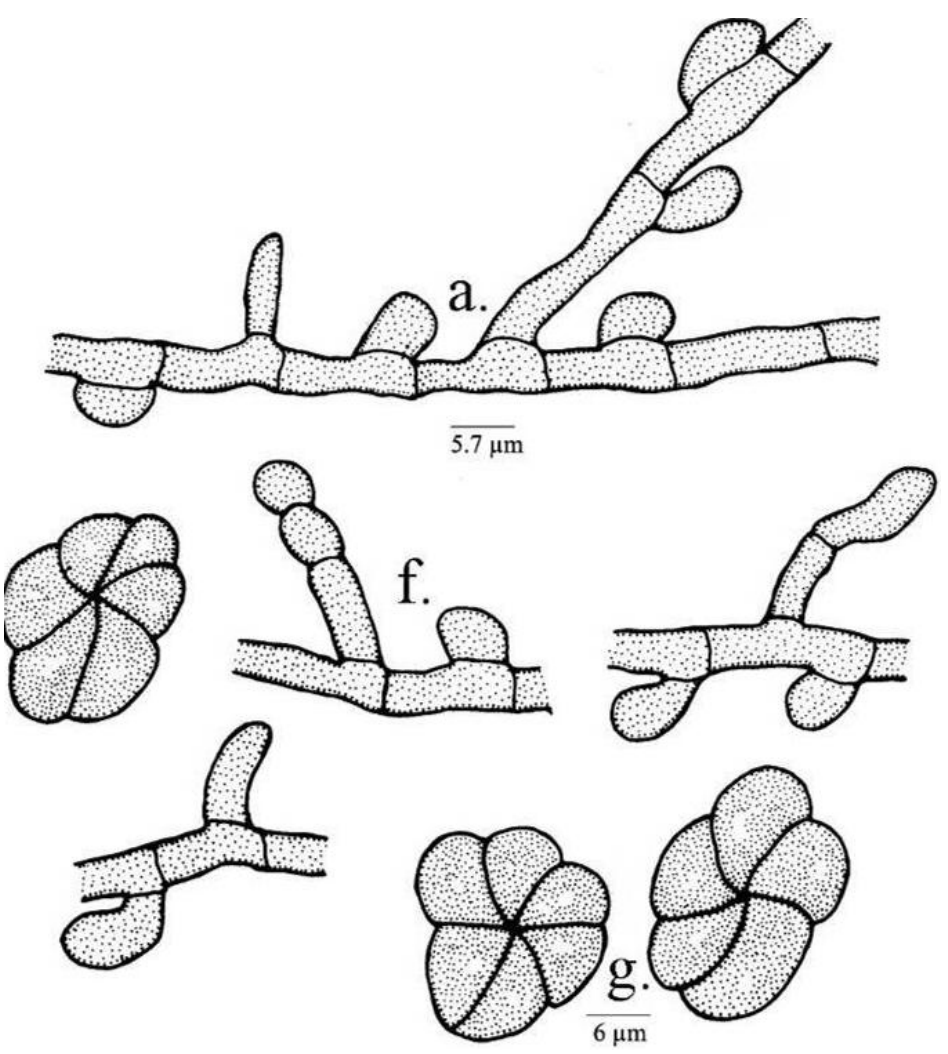

Fig. 21 - Sarcinella hippocrateae 
of Hippocratea sp. (Hippocrataceae), 15 November 2003, V.B. Hosagoudar HCIO 46187, TBGT 1599.

This species was known on this host genus from Uttar Pradesh (Srivastava et al. 1990) and is known from Southern Western Ghats.

Sarcinella hughesii Hosag. \& Venkanna, J. Econ. Taxon. Bot. 17: 457, 1993.

Colonies amphigenous, thin, scattered, up to $2 \mathrm{~mm}$ in diameter. Hyphae flexuous, branching opposite to unilateral at acute to wide angles, loosely reticulate, cells $17-30 \times$ 6-7 $\mu \mathrm{m}$. Appressoria alternate to unilateral, globose, broad based, entire, 5-12 × 7-12 $\mu \mathrm{m}$. Questieriella conidia few, scattered, ellipsoidal, straight to sigmoid, 3-septate, slightly constricted at the septa, 37-45 $\times 9-11 \mu \mathrm{m}$. Sarcinella conidiophores simple, micronematous, monematous, unicellular to septate, 5-25 $\times$ 4-6 $\mu \mathrm{m}$; conidiogenous cells monoblastic, terminal. Conidia solitary, subspherical to oval, sarciniform, 2-5-celled, constricted at the septa, $15-30 \times 15-32 \mu \mathrm{m}$.

Material examined - India, Maharashtra, Mahabaleshwar, on leaves of Nothopodytes foetida (Wight) Slumer. (Icacinaceae), 10 January 1991, P. Venkanna HCIO (holotype), New Delhi; Kerala, Wayanad, Padinharathara, On leaves of Nothopodytes sp., 23 December 2008 M.C. Riju TBGT 5112. Part of the collection has been deposited in HCIO, New Delhi.

Sarcinella hugoniae Hosag. \& Kamar., Zoos Print J. 17: 837, 2002.

(Fig. 23)

Colonies epiphyllous, dense, up to $3 \mathrm{~mm}$ in diameter, often confluent. Hyphae substraight to flexuous, branching irregular at acute angles, loosely to closely reticulate and form solid mycelial mat, cells 16-23 × 7-9 $\mu \mathrm{m}$. Questieriella conidia absent. Sarcenella conidia present; conidiophores macronematous, unicellular to rarely uniseptate, straight to flexuous, $14-18 \times 7-9 \mu \mathrm{m}$; conidiogenous cells monoblastic, integrated, terminal, determinate; conidia solitary, subspherical to ovate, sarciniform, black, 4-6 celled, constricted at the septa, 32-40 × 28-32 $\mu \mathrm{m}$, wall smooth.

Material examined - India, Kerala, Malappuram, on leaves of Hugonia mystax L.
(Linaceae), 3 December 2000, M. Kamarudeen HCIO 44020 (holotype), TBGT 463 (isotype).

This is the only species of Schiffnerulaceous fungi on members of Linaceae and it was hyperparasitized with Acremoniula sarcinellae

Sarcinella indica S. Chandra, Srivast. \& Chaudhary, Indian Phytopath. 44: 303, 1991.

Infection spots epigenous, almost circular and small but becoming large and coalescing with age to cover the whole of the leaf surface, greyish black. Colonies epiphyllous, effuse, brown, mycelium of hyphae superficial, mid olivaceous to brown, composed of net work of laterally to rarely oppositely branched, septate, thick walled cells 4-9 $\mu \mathrm{m}$ diameter. Appressoria mostly unilateral, some times bilateral, hemispherical to subglobose, less coloured than the hyphae, 6-9 $\mu \mathrm{m}$ in diameter. Conidiophores micronematous, mononematous, small, unbranched, straight, rarely flexuous, mid olivaceous to brown, arising usually laterally on the hyphae, simple, smooth walled, slightly paler towards the apex; conidiogenous cells integrated, monoblastic, integrated, terminal, determinate, cylindrical; conidia simple, solitary, acrogenous, dry, subglobose to globose, muriform, smooth, blackish brown to black, deeply constricted at the septa, septa usually cruciately arranged, appearing usually 4-8-lobate in surface view, 11-30 × 6-28 $\mu \mathrm{m}$.

India, Uttar Pradesh, Pithoragarh, on leaves of Sapium insigne Trim. (Euphorbiaceae), date of collection not known, P. Narayan Herb GPU PN 5, IMI 282654 (holotype).

Sarcinella jabalpurensis Rajak. \& Soni, Indian J. Mycol. Plant Pathol. 11: 91, 1981.

Colonies amphigenous, dense, velvety, up to $2 \mathrm{~mm}$ in diametrer, confluent. Hyphae straight to substraight, branched irregularly at acute to wide angles, loosely reticulate, cells 6$8 \mu \mathrm{m}$ thick. Appressoria unilateral, occasionally alternate, light brown to dark brown, hemispherical to subglobose, entire to slightly angular, $10-12 \mu \mathrm{m}$ in diameter. Sarcinella conidiophores small, micronematous, straight to flexuous, simple, arising laterally on the hyphae, light brown to brown, septate, paler towards the apex, 16-30 × 7-8 $\mu \mathrm{m}$; conidia solitary, acrogenous, dry, sarciniform, muri- 


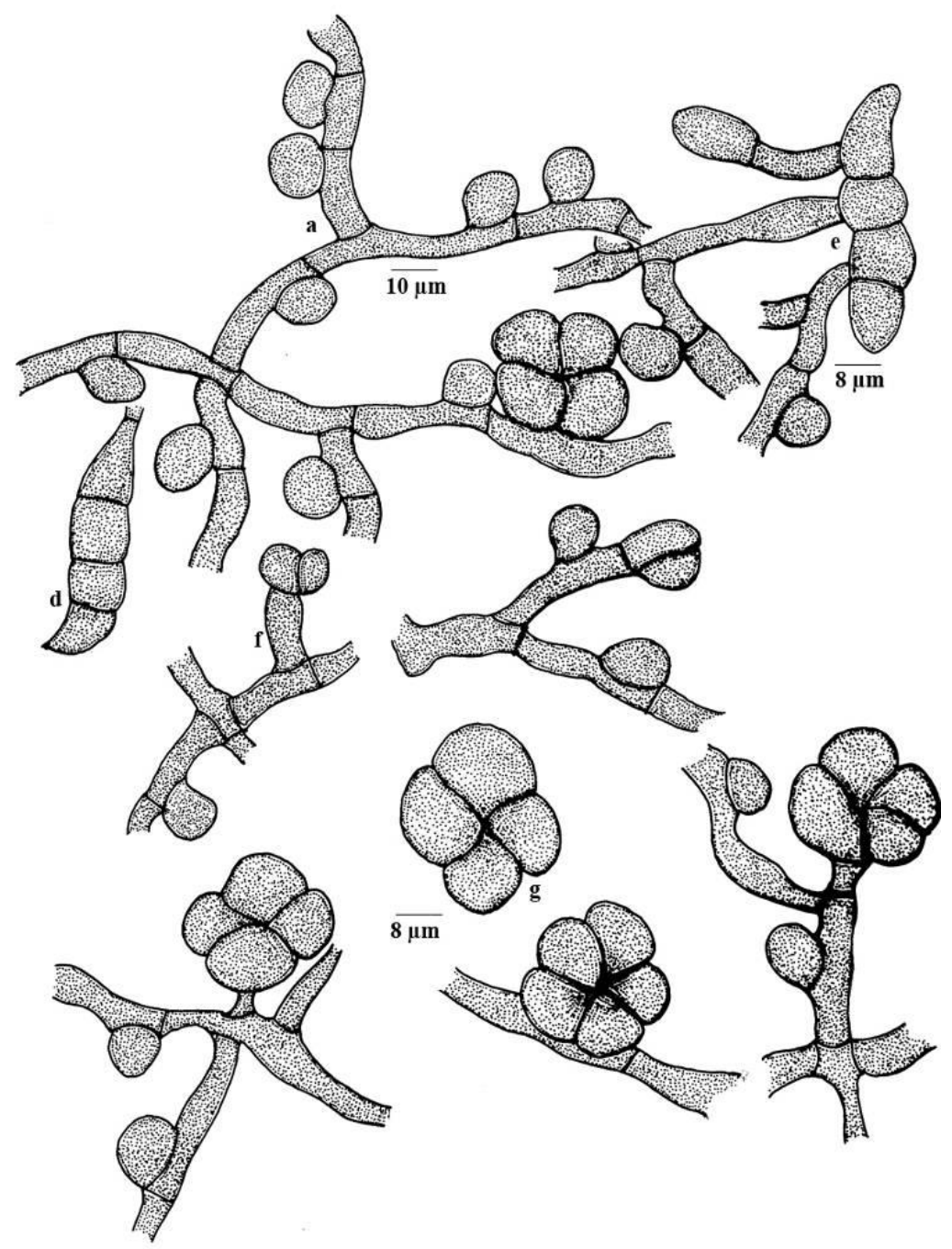

Fig. 22 - Sarcinella hughesii

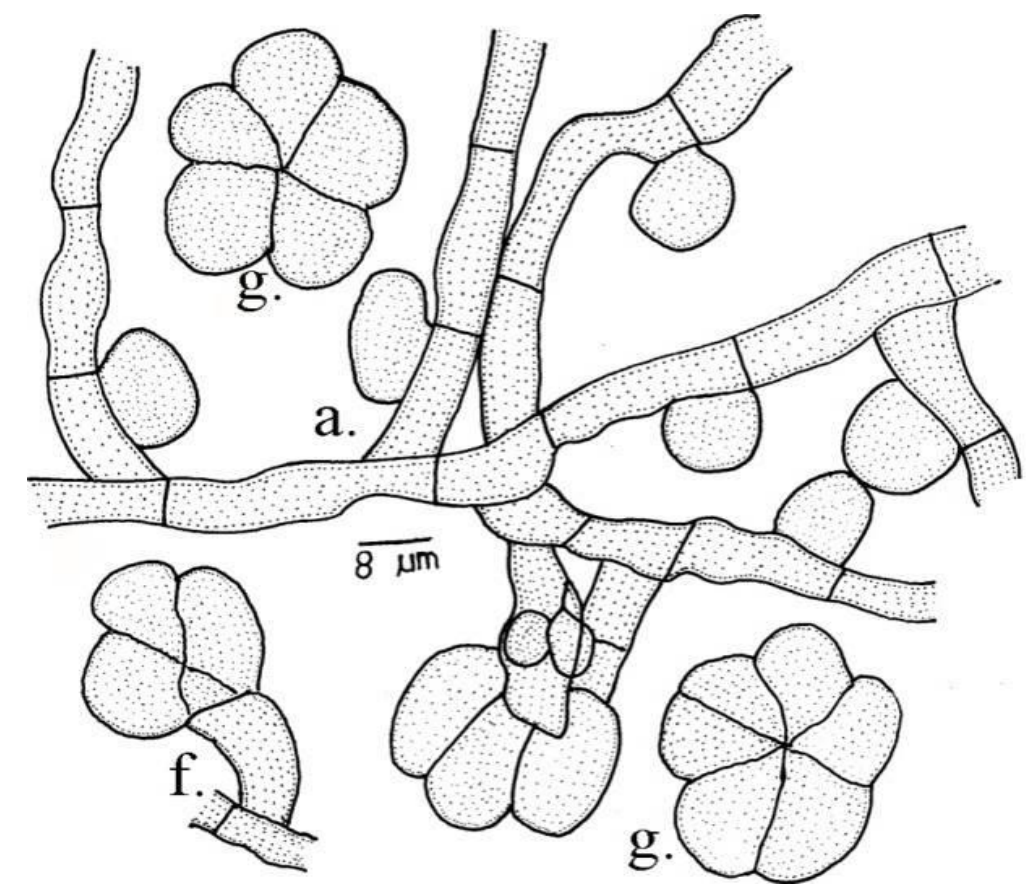

Fig. 23 - Sarcinella hugoniae 
form, brown to dark brown, becoming almost opaque at maturity, 4-10 celled, deeply constricted at the septa, 20-38 $\mu \mathrm{m}$ in diameter. Questieriella conidia borne directly on the hyphae, hyaline, falcate, septate, 3-septate, ends pointed, 20-30 $\times 8-9 \mu \mathrm{m}$.

India, Madhya Pradesh, Jabalpur, Bargi forest, on leaves of Vitex negundo L. (Verbenaceae), December 1977, K.K. Soni IMI 225301.

Sarcinella jarwaensis S. Chandra, N. Srivast. \& Chaudhary, Indian Phytopath. 44: 304, 1991.

Infection spots epigenous, almost circular and small but becoming large and coalescing with age to cover the whole of the leaf surface, black; Colonies epiphyllous, effuse, light brown, mycelium of hyphae superficial, oliveceous brown, composed of net work, branched, branching alternately as well as oppositely, septate, thick walled, cells 5-8 $\mu \mathrm{m}$ broad. Appressoria unilateral as well as bilateral, subglobose, pale olive, $8-15 \times 8-12 \mu \mathrm{m}$ in diameter. Conidiophores micronematous, mononematous, small, unbranched, straight to slightly flexuous, pale olive to light brown, arising usually laterally on the hyphae, simple, smooth walled, slightly paler towards the apex; conidiogenous cells integrated, monoblastic, terminal, determinate, cylindrical; conidia simple, solitary, acrogenous, dry, subglobose to globose, muriform, smooth, pale brown to mid brown, deeply constricted at the septa, septa usually cruciately arranged, appea-ring usually 4-6-lobate in surface view, 15-30 $\mu \mathrm{m}$ in diameter.

India, Uttar Pradesh, Gonda forest division, Jarwa, on leaves of Terminalia chebula Retz. (Combretaceae), date of collection not known, R. Kumar Herb GPU RK 197, IMI 321104.

Sarcinella kamalii Singh \& Singh, Indian Phytopath. 58: 341, 2005.

Lesions indistinct. Colonies hypophyllous, spreading along the margins, sometimes covering whole leaf surface, discrete, black. Mycelium olivaceous to pale brow, branched, septate, 4-6 $\mu \mathrm{m}$ wide. Appressoria abundant, reniform to subglobose, unilateral to bilateral, irregular, pale olivaceous to olive brown, 6-10 $\mu \mathrm{m}$ in diameter. Conidiophores arise laterally from the hyphae, micronematous, simple to rarely branched, straight, 0-1-septate, smooth walled, pale brown, conidiogenous cells integrated, terminal, cylindrical, inflated at the apex, 10-13 × 5-8 $\mu \mathrm{m}$. Conidia solitary, dry, simple, smooth, irregularly sarciniform, muriform with more or less cruciately arranged septa, dark brown to black, constricted at the septa, thick walled, 2-7-lobed, 10-20 × 10-30 $\mu \mathrm{m}$.

India, Karnataka, Sirsi, on leaves of Syzygium cumini (L.) Skeels (Myrtaceae), November 2003, S.K. Singh AMH 9023, HCIO 45890.

This is the first reort of the genus Sarcinella on the members of the family Myrtaceae.

Sarcinella latifoliae N. Srivastava, S. Chandra \& C. Gupta, Vegetos 3: 75, 1990.

Colonies epiphyllous, dense, confluent. Hyphae pale brown to olivaceous, alternate to oppositely branched, 3-6 $\mu \mathrm{m}$ thick. Appressoria numerous, alternate, pale brown, hemispherical to subglobose, 7-12 × 5-10 $\mu \mathrm{m}$. Sarcinella conidiophores micronematous, arising laterally from the hyphae, short, simple, straight, smooth, pale brown, conidiogenous cells monoblastic, integrated, terminal, cylindrical; conidia solitary, dry, simple, smooth, subglobose to irregularly sarciniform, muriform with more or less cruciately arranged septa, dark brown to black, deeply constricted at the septa, appearing 4-8 lobed, 21-37 × 15$28 \mu \mathrm{m}$. India, Uttar Pradesh, Mandla, on leaves of Ampelocissus latifolia (Roxb.) Planch (Vitaceae), C. Gupta GUP KC 98, I, IMI 311428 (holotype).

Sarcinella limoniae Hosag., Sabeena \& Riju, Indian Phytopath. 63: 236, $2010 . \quad$ (Fig. 24)

Colonies amphigenous, subdense, scattered, up to $1 \mathrm{~mm}$ in diameter, rarely confluent. Hyphae substraight to flexuous, branching opposite, alternate to irregular at acute to wide angles, loosely reticulate, cells $12-37 \times 5-7$ $\mu \mathrm{m}$. Appressoria opposite, alternate to unilateral, one celled, globose, broad based, entire, 5$10 \times 5-12 \mu \mathrm{m}$. Questieriella conidia few, scattered in the colonies, pale brown, 3-septate, slightly constricted at the septa, $25-55 \times 7-15$ $\mu \mathrm{m}$.

Sarcinella conidiophores simple, micronematous, unicellular to septate, 5-25 $\times 5-10$ 


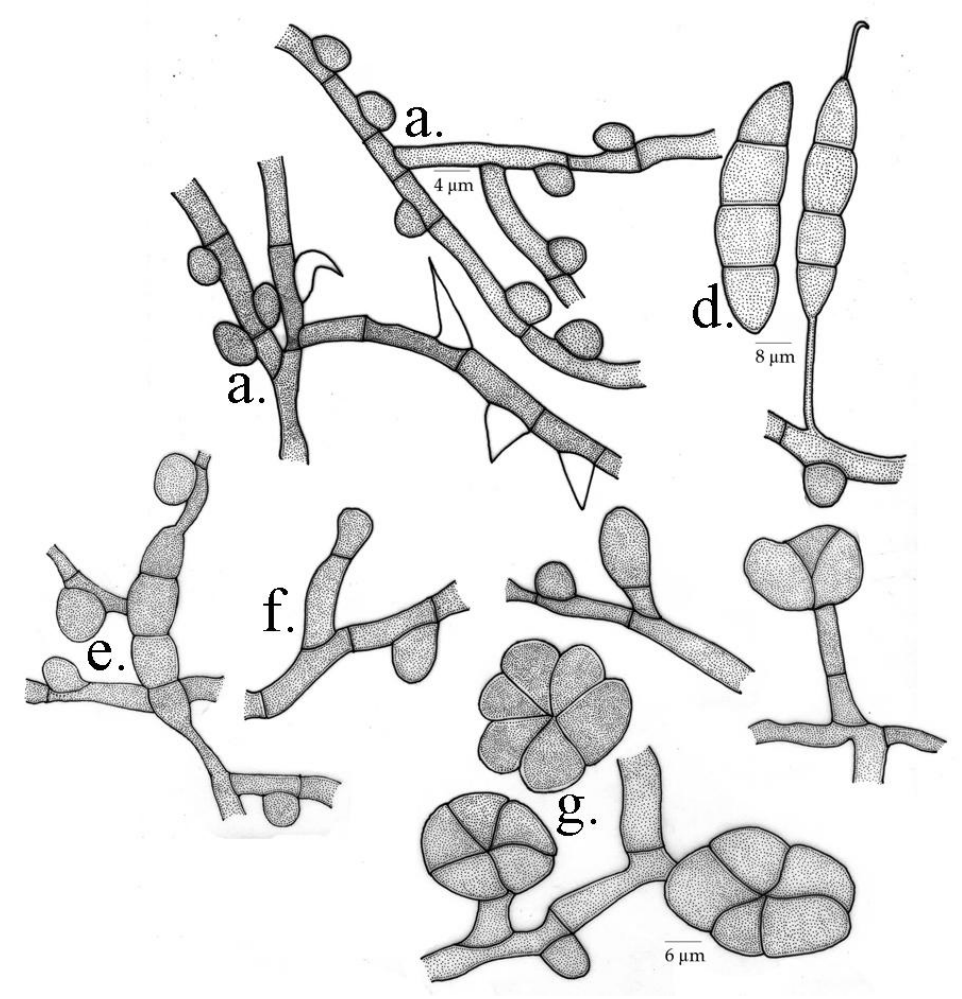

Fig. 24 - Sarcinella limoniae

$\mu \mathrm{m}$; conidiogenous cells integrated, monoblastic, polyblastic, terminal, cylindrical; conidia solitary, acrogenous, subspherical, oval, sarciniform, 2-6 celled, constricted at the septa, 25$37 \times 25-30 \mu \mathrm{m}$.

Material examined - India, Kerala, Thiruvananthapuram, Palode, TBGRI Campus,on leaves of Limonia altissima L. (Rutaceae), 2 November 2007, A. Sabeena \& M.C. Riju HCIO 48855 (holotype), TBGT 3231 (isotype).

Two species of the genus Sarcinella, namely, S. fumosa Sahni and S. glycosmidis Kamal \& Singh are known on members of the family Rutaceae (Sahni 1964, Kamal \& Singh 1980, Hosagoudar 2003b). This species differs from $S$. glycosmidis in having amphigenous colonies, both opposite and alternate aprèssoria in contrast to alternate ones and also differs from it in having Questieriella conidia. It differs from $S$. fumosa in having distinctly larger Questieriella conidia (25-55 × 7-15 $\mu \mathrm{m}$ against 25-33 $\times 6-9 \mu \mathrm{m})$ and Sarcinella conidia $(25-37 \mu \mathrm{m}$ against $21-29 \mu \mathrm{m})$.

Sarcinella loranthacearum Hosag., JacobThomas \& Agarwal, J. Yeast \& Fungal Res. 2:85, 2011.
Colonies epiphyllous, dense, up to $2 \mathrm{~mm}$ in diameter, confluent. Hyphae brown, straight to substraight, branching alternate to opposite at acute to wide angles, closely reticulate, cells 16-28 $\times$ 4-7 $\mu \mathrm{m}$. Appressoria alternate, unicellular, ovate to globose, entire, 9-12 × 7$10 \mu \mathrm{m}$. Conidiophores micronematous, mononematous, simple, straight, light brown, arise laterally from the hyphae, smooth, 9-14 × 7-10 $\mu \mathrm{m}$; conidiogenous cells integrated, mostly terminal, monoblastic, determinate, cylindrical; conidia simple, solitary, dry, acrogenous, globose, smooth, brown to carbonaceous black, constricted, 5-8 celled, carcinate, 24-29 $\mu \mathrm{m}$ in diameter. Questeriella conidia present, straight to slightly falcate, 3-septate, brown, 26-36 × 7-10 $\mu \mathrm{m}$, wall smooth.

Material examined - India, Kerala, Palakkad, Silent Valley National Park, on leaves of Loranthus sp. (Loranthaceae), 12 July 2008, Jacob Thomas \& al HCIO 49041 (holotype), TBGT 3296 (isotype).

This is the only report of the genus Sarcinella on the members of the family Loranthaceae. 


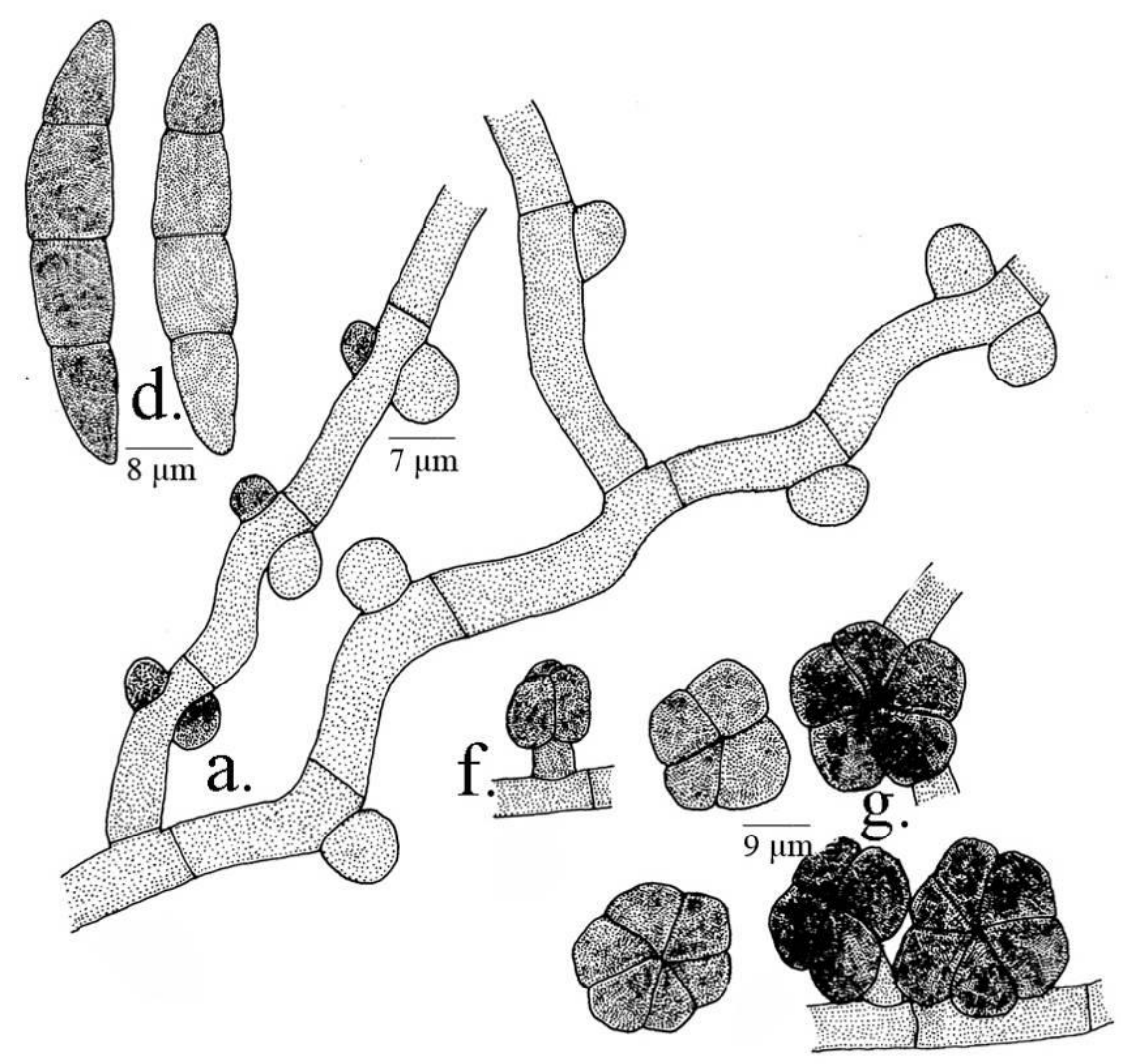

Fig. 25 - Sarcinella loranthacearum

Sarcinella lyoniae Hosag., Jacob Thomas Robin, Indian J. Sci. \& Techn. 2(6):5, 2009.

(Fig. 26)

Colonies epiphyllous, thin, spreading, up to $2 \mathrm{~mm}$ in diameter, confluent and cover the larger area of upper surface of leaves. Hyphae pale brown, sub straight to undulate, branching alternate to opposite at acute to wide angles, loosely reticulate, cells 9-29 $\times 2-5 \mu \mathrm{m}$. Appressoria scattered, alternate to unilateral, straight, ovate, globose, unicellular, broad based, margin entire, sessile, 7-10 × 12-14 $\mu \mathrm{m}$. Conidiophores borne lateral to the hyphae, become erect, unicellular, gibbous at the base, micronematous, mononematous, simple, straight, 4-10 $\mu \mathrm{m}$ in diameter; conidiophores of Sarcinella form were micronematous, mononematus, simple, straight, mostly unicellular, 9-12 × 4-5 $\mu \mathrm{m}$; conidiogenous cells terminal, integrated, monoblastic, determinate, cylindrical; conidia simple, solitary, dry, acrogenous, subglobose to globose, 4-12-celled, sarciniform, constricted at the septa, charcoal black, $24-31 \mu \mathrm{m}$ in diameter, wall smooth. Several conidia of Quisteriella form were scattered in the colony and were germinating by producing mycelium and appressoria. Conidia pale brown 3-septate, slightly constricted at the septum, slightly curved, falcate, 33-41 × 7-10 $\mu \mathrm{m}$, end cells pale, attenuated at the tip.

Material examined - India, Meghalaya, Shillong, Mawphlang, on the leaves of Lyonia ovalifolia (Wall.) Drude (Ericaceae), 20 January 2007, Jacob Thomas \& P.J. Robin. HCIO 48067 (holotype), TBGT 2850 (isotype).

The present fungus reveals two anamorph states, namely, Sarcinella and Questieriella. Hughes (1987) has given a list of the genus Schiffnerula and Hosagoudar (2003b) has updated it. There are no records of any Schiffnerulaceous fungi on the members of the host family Ericaceae.

Sarcinella odinae Sahni, Mycopathol. Mycol. Appl. 23: 336, 1964.

Colonies foliicolous, epiphyllous, up to 2 $\mathrm{mm}$ in diameter, confluent. Hyphae straight to substraight, branching alternate to irregular at acute to wide angles, loosely reticulate. Appressoria subglobose, entire. Sarcinella conidia stipitate, dark, opaque, 4-6-celled, 25-43 $\mu \mathrm{m}$ in diameter. Questieriaella conidia pale brown, 3-septate, falcate, acute at both ends, 30-49 × 6-11 $\mu \mathrm{m}$. 


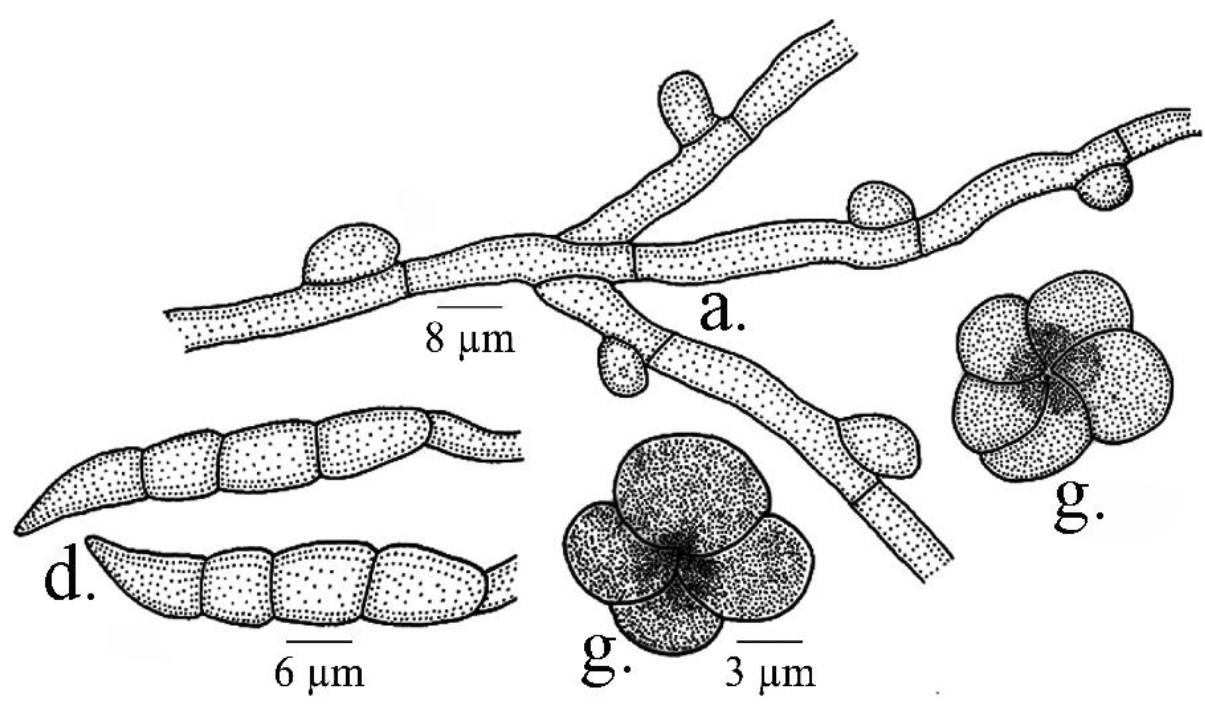

Fig. 26 - Sarcinella lyoniae

India, Madhya Pradesh, Jabalpur, Kundam Road, on leaves of Odina wodier Roxb. (Anacardiaceae), September 1962, V.P. Sahni IMI 96664 (holotype).

Sarcinella oreocnidecola Hosag., Mycopathol. Res. 44: 47, 2006. (Fig. 27)

Colonies epiphyllous, thin, up to $3 \mathrm{~mm}$ in diameter. Hyphae straight to substraight, branching alternate to opposite at acute to wide angles, loosely to closely reticulate, cells 9-16 $\times$ 4-6 $\mu \mathrm{m}$. Appressoria scattered, alternate to unilateral, globose, entire, $8-10 \mu \mathrm{m}$ in diameter. Conidiophores micronematous, mononematous, concolorous, mostly simple, mostly unicellular, rarely 1-2-septate, straight, pale brown, $18-22 \times 5-7 \mu \mathrm{m}$; conidiogenous cells monoblastic, integrated, mostly terminal, determinate, cylindrical; conidia solitary, dry, acrogenous, simple, subspherical, sarciniform, brown when young, charcoal black at maturity, sarcinately septate, constricted at the septa, smooth, 19-30 $\mu \mathrm{m}$ in diameter.

Material examined - India, Kerala, Palghat, Silent Valley National Park, Sairandhri, on leaves of Oreocnide integrifolia (Gaud. ex Wedd.) Miq. (Urticaceae), 13 December 2003, V.B. Hosagoudar \& al. HCIO 45771, TBGT 1520 .

Sarcinella pouzolziae is known on Pouzolzia sp. from the Western Ghats. Sarcinella oreocnidecola differs from it in having shorter conidiophores and smaller conidia. However, host specificity has been considered here as criteria for the segregation of the species.

Sarcinella oreophila H. Sydow, Ann. Mycol. 35: 242, 1937.

(Fig. 28)

Colonies amphigenous, subdense, up to 3 $\mathrm{mm}$ in diameter, confluent. Hyphae pale brown, straight, branching irregular, at acute angles, loosely reticulate, cells $19-31 \times 2-5$ $\mu \mathrm{m}$. Appressoria alternate to unilateral, unicellular, globose, margin entire, 6-8 $\times 5-7$ $\mu \mathrm{m}$. Conidiophores macronematous, micronematous, simple, straight, short, light brown, arise laterally from the hyphae, smooth, 3-5 $\times$ 4-5 $\mu \mathrm{m}$. Conidiogenous cells integrated, terminal, monoblastic, cylindrical. Conidia simple, dry, solitary, acrogenous, globose, smooth, dark brown, constricted at the septa, cells 3-8, sarcinately arranged, 13-22 × 11-20 $\mu \mathrm{m}$.

Material examined - India, Kerala, Alappuzha, Chengannur, Karakkad, on leaves of Carissa carandas L. (Apocyanaceae), 21 October 2007, M. Harish TBGT 3129.

Sarcinella pouzolziae Hosag., J. Mycopathol. Res. 44: 20, 2006.

Colonies epiphyllous, thin to subdense, up to $2 \mathrm{~mm}$ in diameter, rarely confluent. Hyphae flexuous, branching irregular at acute to wide angles, loosely reticulate, cells $12-18 \times$ 4-6 $\mu \mathrm{m}$. Appressoria alternate, unilateral, more scattered, spherical, entire, concolorous, 9-11 $\times$ 6-8 $\mu \mathrm{m}$. Conidia of Questieriella were scattered, not attached, pale brown, fusiform, curved, 3-septate, constricted at the septa, taper towards both ends, $3-34 \times 8-10 \mu \mathrm{m}$. 


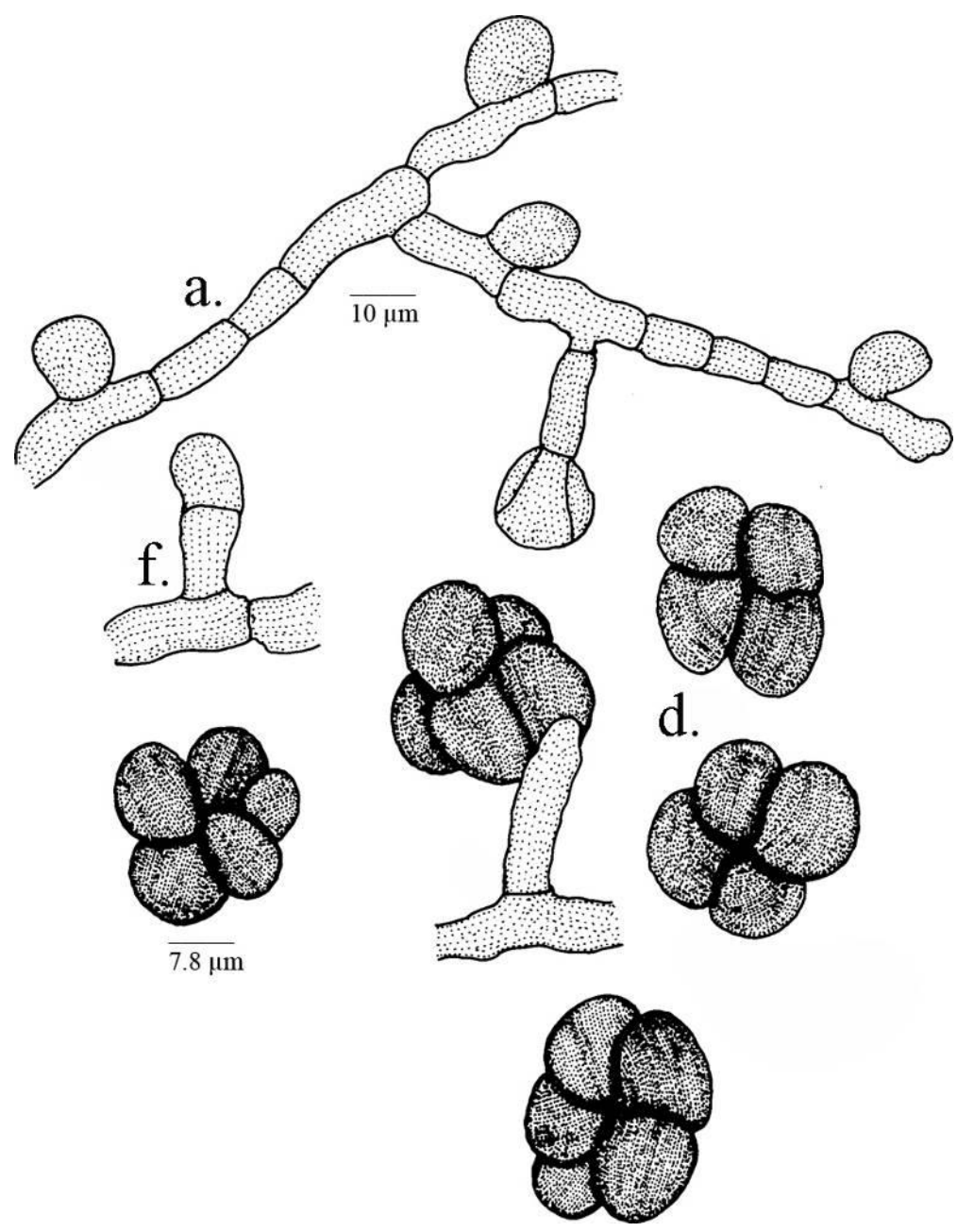

Fig. 27 - Sarcinella oreocnidecola
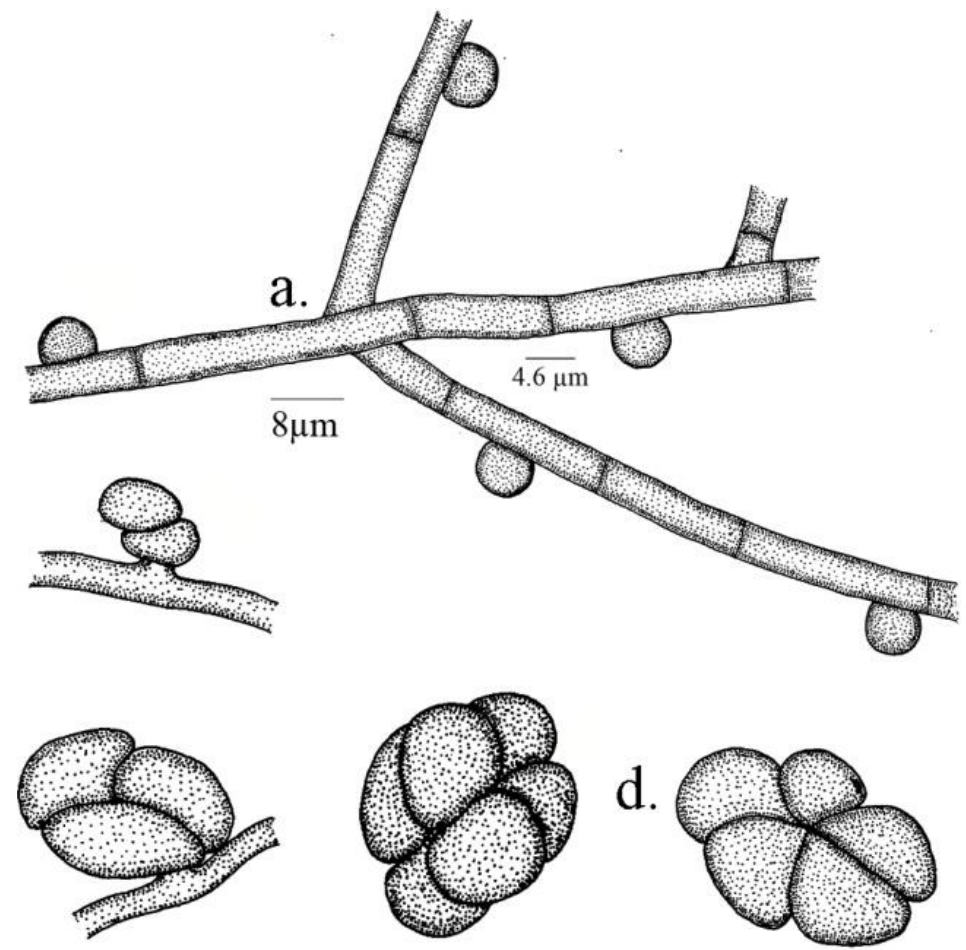

Fig. 28 - Sarcinella oreophila 


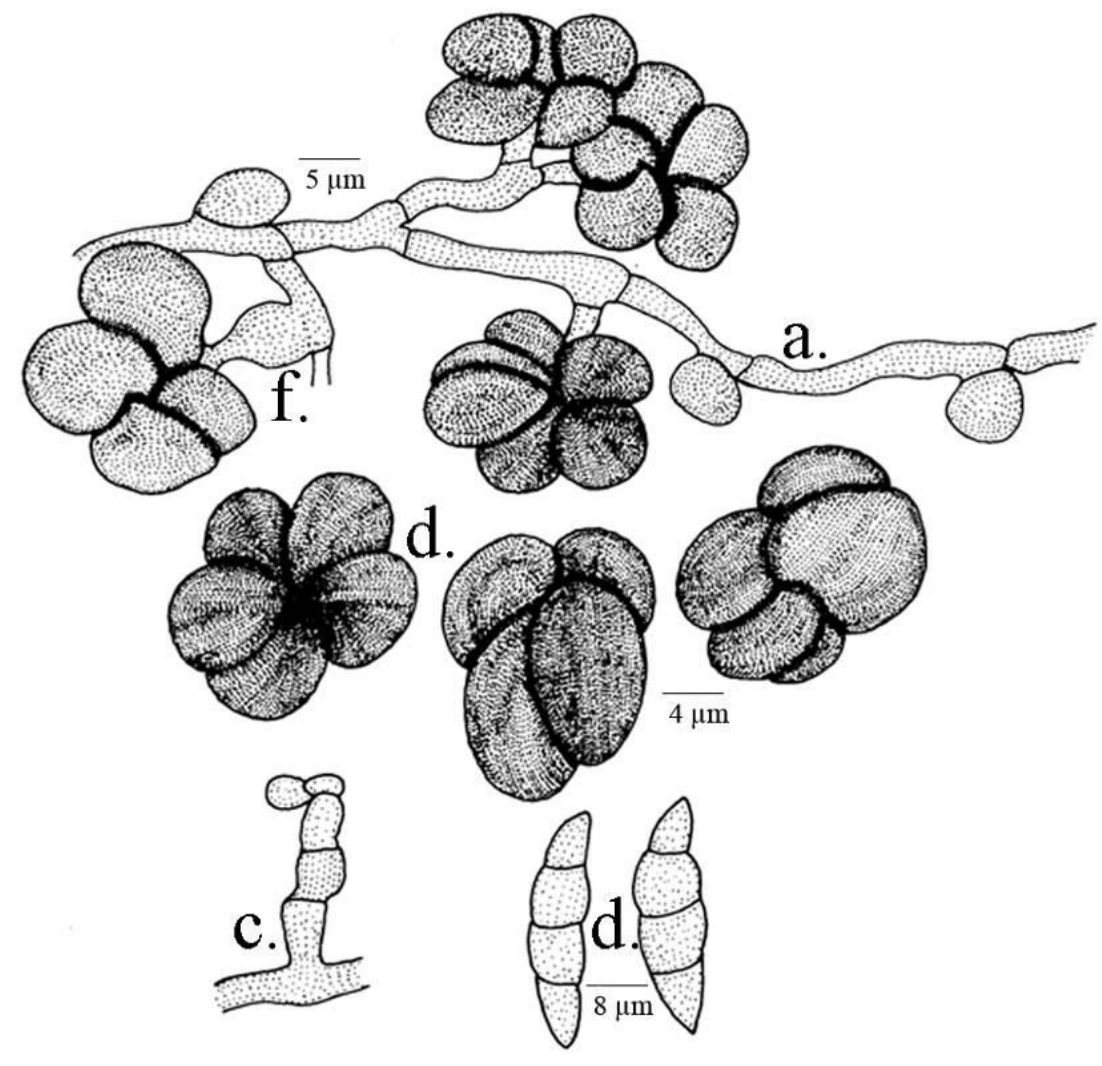

Fig. 29 - Sarcinella pouzolziae

Sarcinella - Conidiophores micronematous, concolorous, mostly simple, rarely branched, straight to flexuous, pale brown, 0-2-septate, smooth, 25-35 × 5-7 $\mu \mathrm{m}$; conidiogenous cells monoblastic, integrated, mostly terminal, determinate, cylindrical; conidia solitary, dry, acrogenous, simple, subspherical, sarciniform, brown when young, charcoal black at maturity, sarcinately septate, constricted at the septa, smooth, 16-20 $\mu \mathrm{m}$ in diameter.

Material examined - India, Karnataka, Coorg, Madikeri, Nishane motta, on leaves of Pouzolzia sp. (Urticaceae), 13 November 2003, V.B. Hosagoudar \& al. HCIO 45816 (holotype), TBGT 1566 (isotype).

This is the only Schiffnerulaceous fungi on members of the family Urticaceae (Hosagoudar 2003b).

Sarcinella prunicola Pavgi \& Singh, Sydowia 24: 115, 1970.

Colonies epiphyllous, irregular, dense, velvety, scattered to confluent, corresponding lower surface of the colonies turned yellow. Sarcinella conidiophores small, short, conidia many celled, black, subcylindrical to globoid, $19-55 \mu \mathrm{m}$ in diameter
India, West Bengal, Darjeeling, on leaves of Prunus persica (L.) Batch (Rosaceae), 24 November 1964, U.P. Singh MSP 354, IMI 113598 (holotype).

Known only from the type collection.

Sarcinella quercina Verma \& Kamal, Trans. Brit. Mycol. Soc. 89: 70, 1987.

Lesions epigenous, covering almost the whole leaf surface. Colonies spreading extensively, powdery, black. Mycelium of the superficial, pale brown to olivaceous, repent hyphae, branched and forming a loose but well developed network on the leaf surface, septate, smooth or roughened, 3-6 $\mu \mathrm{m}$ wide, appressoriate. Appressoria abundant, reniform to tetrahedral or subglobose, pale brown, alternate, $10-15 \times 7-11 \mu \mathrm{m}$. Conidiophores micronematous, arising laterally from the superficial hyphae, short, simple, straight, smooth, pale brown. Conidiogenous cells monoblastic, integrated, terminal, cylindrical, determinate. Conidia solitary, dry, simple, smooth, subglobose to irregularly sarciniiform, muriform, with more or less cruciately arranged septa, dark brown to black, strongly constricted at the septa, thick 
walled, appearing 4-14-lobed, 25-40 × 18-31 $\mu \mathrm{m}$.

India, Uttar Pradesh, Nainital, on leaves of Quercus dilatata (Fagaceae), October 1985, R.K. Verma GPU KK 106, IMI 299162 (holotype).

Sarcinella quesqualidis Hosag. \& Jacob Thomas, Indian J. Sci. \& Techn. 2 (6): 26, 2009.

(Figs 30-31)

Colonies amphigenous, mostly epiphyllous, dense, velvety, up to $2 \mathrm{~mm}$ in diameter, confluent. Hyphae deep brown, substraight to flexuous, branching opposite to alternate at acute angles, closely reticulate, cells $12-26 \times 4$ $7 \mu \mathrm{m}$. Appressoria alternate, unicellular, globose, subglobose to mammiform, entire, 7-12 $\times$ 9-12 $\mu \mathrm{m}$. Conidiophores macronematous, mononematous, simple, straight, produced lateral to the hyphae, smooth, 7-15 $\mu \mathrm{m}$ long; conidiogenous cells integrated, mostly terminal, monoblastic, determinate, cylindrical; conidia simple, solitary, dry, acrogenous, globose to slightly oval, smooth, carbonaceous black, constricted at the septa, 4-8-celled, cells sarciniform, 28$36 \times 24-31 \mu \mathrm{m}$. Conidia of Questieriella were scattered in the colonies, 3-septate, slightly constricted at the septa, brown to deep brown, falcate, end cells attenuated, 31-43 × 9-12 $\mu \mathrm{m}$, wall smooth.

Material examined - India, Kerala, Thiruvananthapuram, Peppara Wildlife Sanctuary, on leaves of Quisqualis indica L. (Combretaceae), 18 November 2007, Jacob Thomas and Vimal Kumar HCIO 48254 (holotype), TBGT 2993 (isotype).

Questieriella terminaliae Hosag. \& Agarwal and Sarcinella jarwaensis Chandra et al. (Chandra et al. 1991, Hosagoudar et al. 2002) are known on Terminalia chebula from Uttar Pradesh and Kerala States but this is the first report on this host genus.

Sarcinella raimundi Sacc., Ann. Mycol. 12: 313, 1914; Hosag., Zoos' Print J. 21: 2306, 2006.

(Fig. 32)

Colonies epiphyllous, dense, crustose, up to $0.5 \mathrm{~mm}$ in diameter, confluent and uniformly scattered on the leaves. Hyphae crooked, zigzag, form net, branching irregular at acute to wide angles, loosely to closely reticulate, form a loose net, cells 16-24 × 5-7 $\mu \mathrm{m}$. Appressoria scattered, globose, mammiform, entire, 6-8 $\times$ 9-11 $\mu \mathrm{m}$. The conidiophores of Sarcinella were micronematous, micronematous, simple, rarely branched, straight to flexuous, 1-3celled, 16-25 × 7-9 $\mu \mathrm{m}$; conidiogenous cells integrated, terminal, monoblastic, determinate, cylindrical. Conidia simple, solitary, dry, acrogenous, ovate, subglobose to globose, 4-9celled, constricted at the septa, charcoal black, sarciniform, $32-40 \times 24-28 \mu \mathrm{m}$. Several conidia of Questieriella were detached, scattered in the colonies and were germinating. Conidia slightly curved, pale brown, falcate, 3septate, slightly constricted at the septa, end cells attenuated, 25-32 $\mu \mathrm{m}$ long; 9-12 $\mu \mathrm{m}$ broad at the middle.

Material examined - India, Kerala, Ernakulam, Chalakudy, Chettikulam, on leaves of Solanum sp. (Solanaceae), 22 October 2002, H. Biju \& A. Manoj Kumar HCIO 44704, TBGT 985.

This species was earlier known from Philippines (Kranz 1966).

Sarcinella shamboodarai Sharma, Rai \& Vyas, Indian J. Mycol. Plant Pathol. 26: 313, 1996.

(Fig.33)

Colonies amphigenous, mostly epiphyllous, initially small but enlarge with age to coalesce and cover the entire leaf surface. Hyphae substraight, flexuous to slightly crooked, branching alternate to irregular at acute to wide angles, loosely to closely reticulate, cells 4-8 $\mu \mathrm{m}$ wide. Appressora alternate to mostly unilateral, ovoid, subcylindrical, subglobose to hemispherical, light to mid olivaceous, 5-11 $\times 4-9 \mu \mathrm{m}$. Conidiophores arise laterally on the hypahe, small, micronematous, unbranched, straight, simple, smooth walled, slightly paler towards the apex, light to mid olivacous, 9-17 $\mu \mathrm{m}$ long. Conidiogenous cells integrated, terminal, monoblastic, determinate, cylindrical. Conidia simple, solitay, dry, acrogenous, smooth, subsphaerical to top shaped, cruciate to muriform, strongly constricted at the septa, sarciniform, septa usually cruciately arranged, dark olivaceous to black, $10-34 \times 15-24 \mu \mathrm{m}$.

Material examined - India, Madhya Pradesh, Shadol circle, Amarakantak (S.F.D.), Shambhoodhara, on leaves of Elaeodendron 


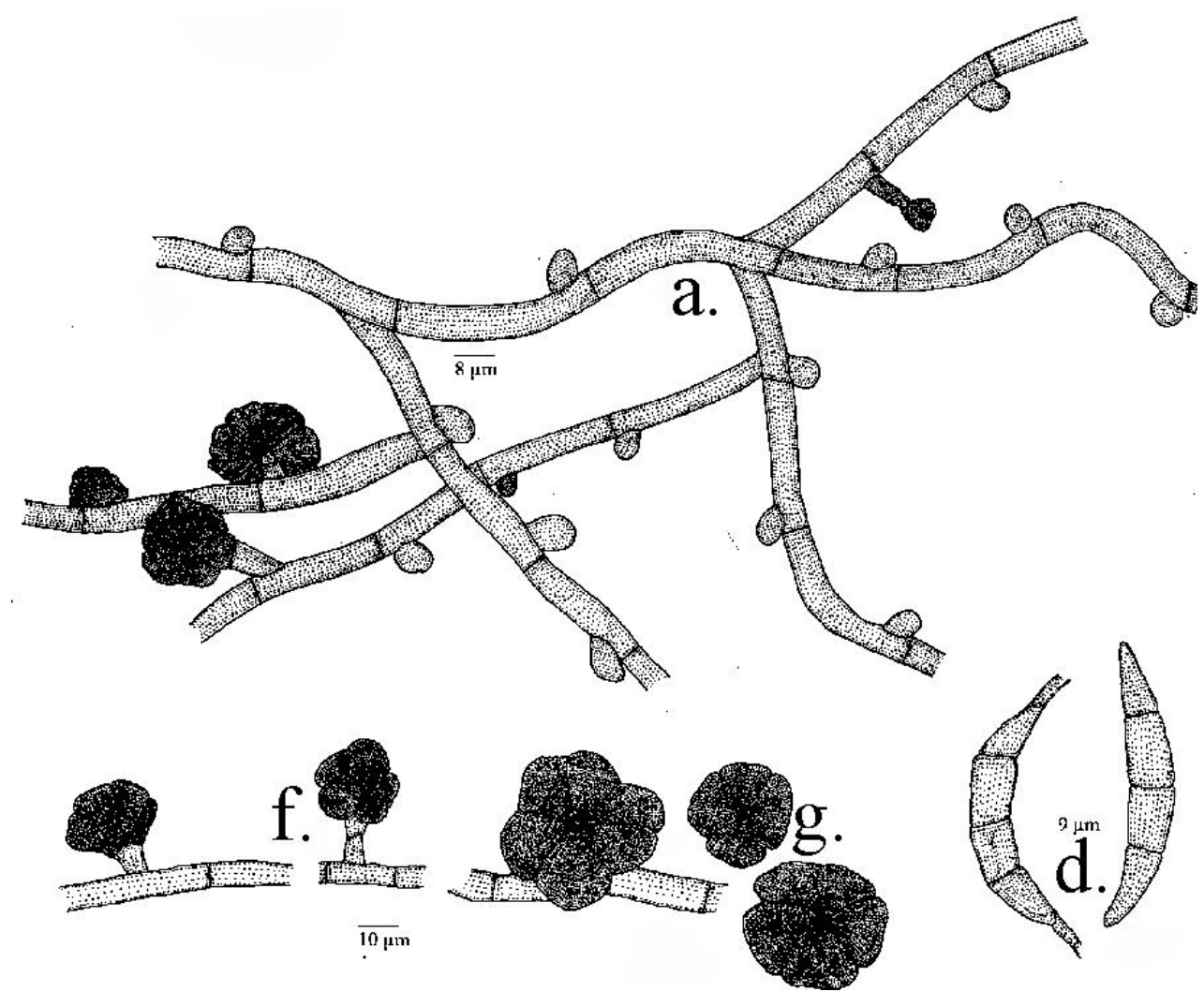

Fig. 30 - Sarcinella quesqualidis

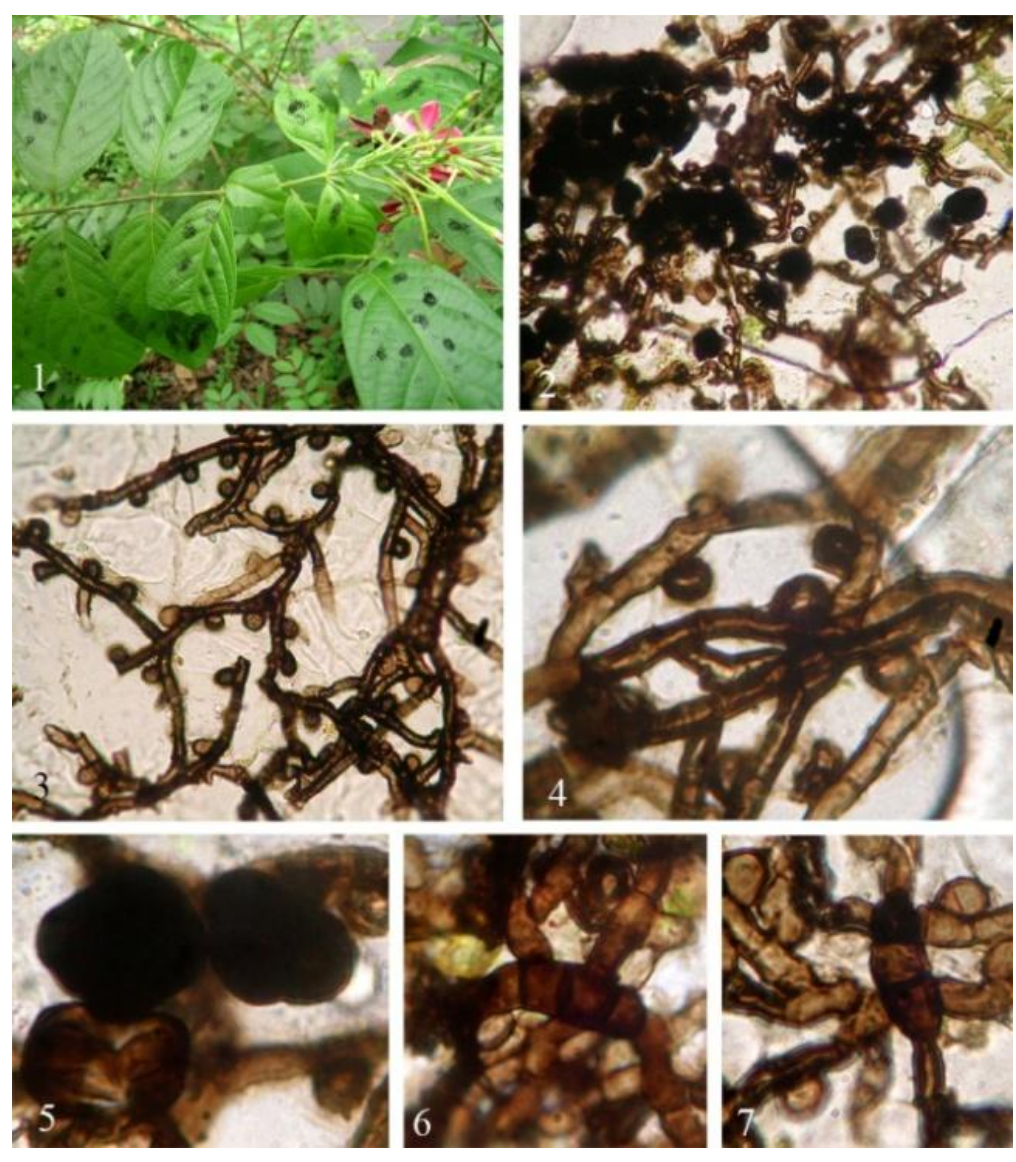

Fig. 31 - Sarcinella quesqualidis, 1 Infected leaves, 2 Colony with Sarcinella conidia, 3 Appressoriate mycelium, 4 Globose appressoria, 5 Sarcinella conidia, 6-7 Germinating Questieriella conidia. 


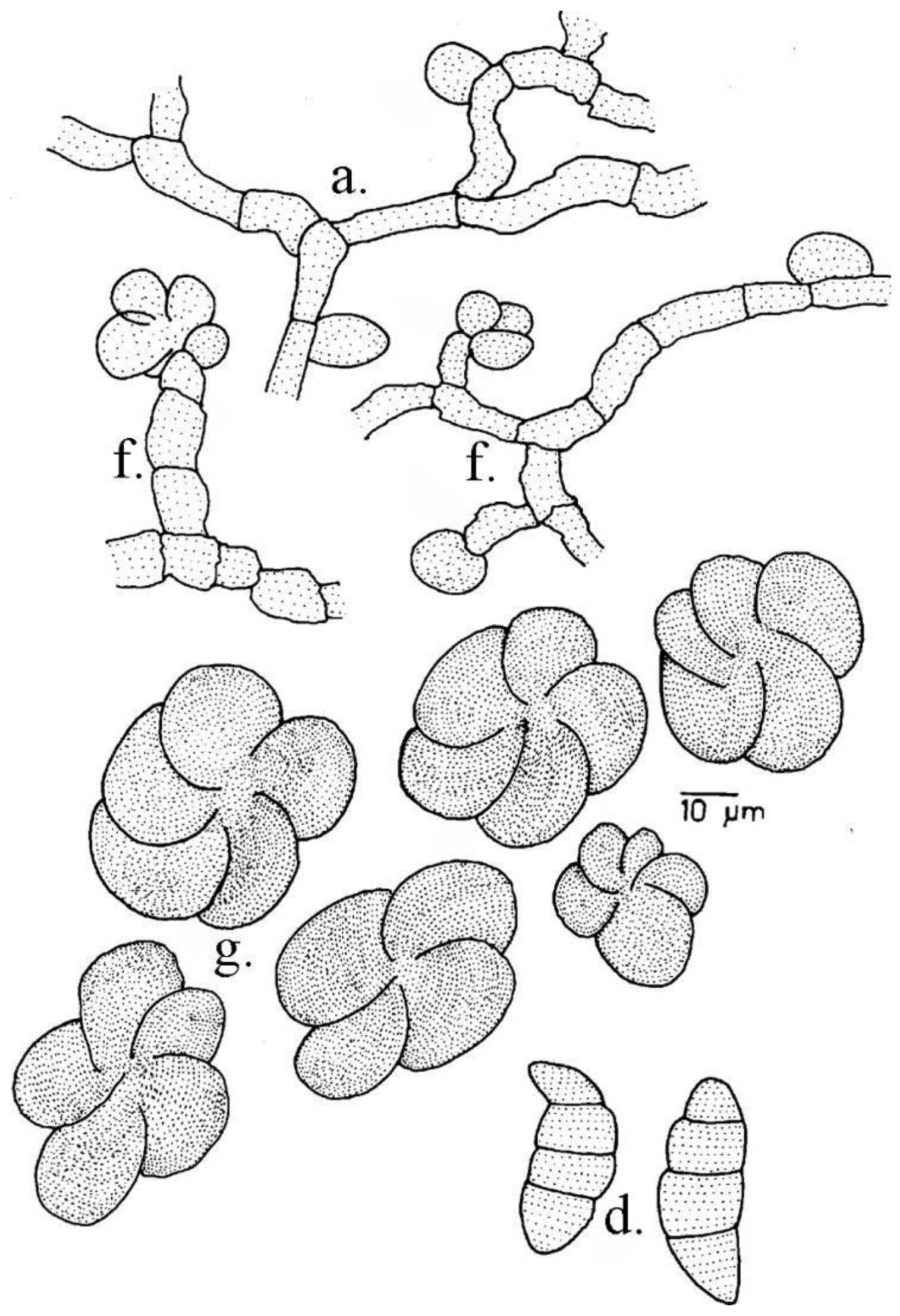

Fig. 32 - Sarcinella raimundi 


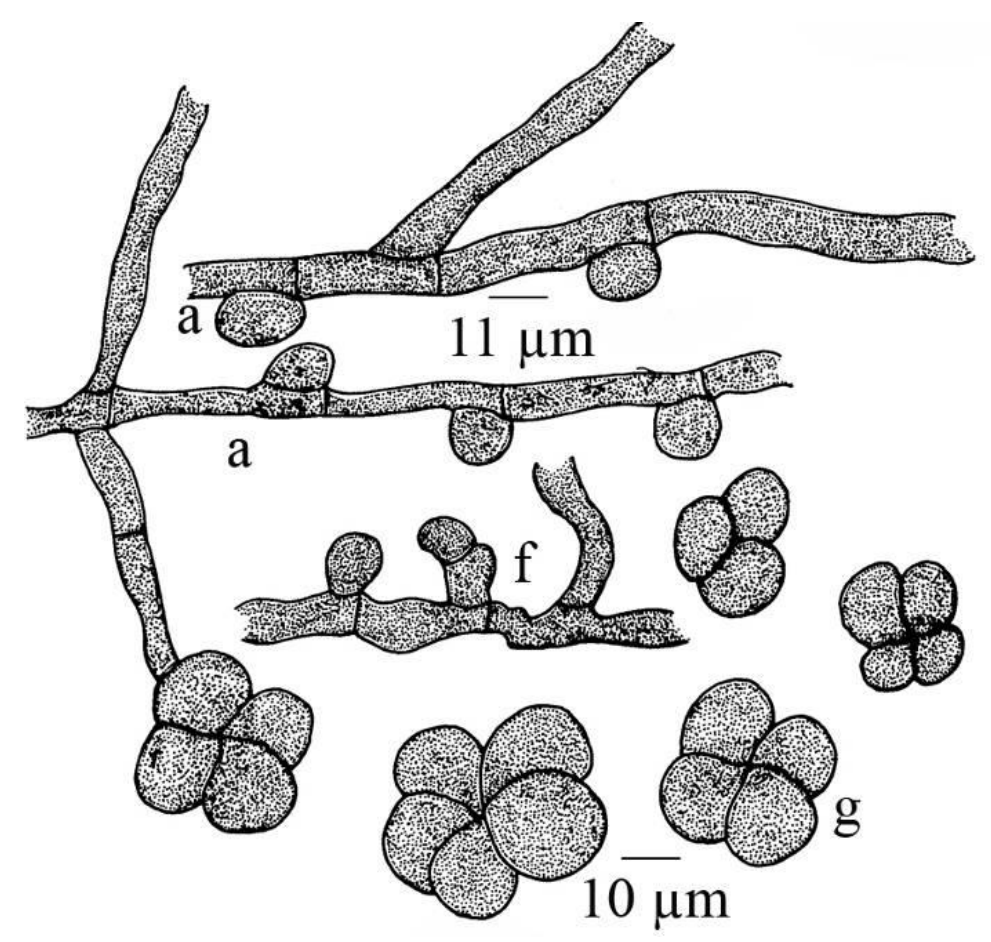

Fig. 33 - Sarcinella shamboodarai glaucum Pers. (Celastraceae), January 1993, C.D. Sharma IMI 356774, S.U. Herb. No. C.S. 10; Maharashtra, Satara, Pateghar, on leaves of Elaeodendron sp., 3 January 2009, V.B. Hosagoudar \& al. HCIO 49341; TBGT 3586.

Sarcinella tamarindi Hosag. \& Riju, Mycosphere 2(2): 157, 2011. (Figs 34-35)

Colonies amphigenous, thin, scattered, up to $3 \mathrm{~mm}$ in diameter. Hyphae substraight, branching mostly opposite, alternate to irregular at acute to wide angles, loosely reticulate, cells $15-28 \times 2-5 \mu \mathrm{m}$. Appressoria alternate to unilateral, one celled, globose, broad based, entire, 7-8 × 5-8 $\mu \mathrm{m}$. Questieriella conidia few, monoblastic, polyblastic, terminal, cylindrical; conidia solitary, acrogenous, subspherical, oval, sarciniform, 2-7 celled, constricted at the septa, 25-38 × 18-32 $\mu \mathrm{m}$, wall smooth, brown in colour.

Material examined - India, Kerala, Wayanad, $16^{\text {th }}$ mile Padinharathara, on living leaves of Tamarindus indica L. (Caesalpiniaceae), 10 October 2010, M.C. Riju TBGT 4512 (holotype). Part of the collection deposited in HCIO, New Delhi.

This fungus was associated with the colonies of Meliola tamarindi.

Sarcinella tandonii Mitter, Ann. Mycol. 35: 243, 1937.
Colonies epiphyllous, rarely few are hypophyllous, orbicular to irregular, $1-4 \mathrm{~mm}$ in diameter Hyphae pale brown, reticulate, 4-6 $\mu \mathrm{m}$ broad. Appressoria alternate, often solitary, globose to subglobose, rarely ovate, unicellular, $10-13 \mu \mathrm{m}$ in diameter, pale brown. Conidia produced laterally from the hyphae, more or less orbicular, initially 4-6-celled, up to 20celled at maturity, charcoal black, $10-14 \times 9$ $13 \mu \mathrm{m}$.

India, Nainital, on leaves of Euonymous tingens.

Known only from the report.

Sarcinella theae Hosag., J. Mycopathol. Res. 43: 208, 2005.

(Fig. 36)

Colonies amphigenous, dense, up to 2 $\mathrm{mm}$ in diameter, confluent. Hyphae substraight to flexuous, branching irregular at acute to wide angles, loosely to closely reticulate, cells 12-16 $\times 4-5 \mu \mathrm{m}$. Appressoria alternate to unilateral, globose, entire, 9-12 $\mu \mathrm{m}$ in diameter. Conidiophores micronematous, mononematous, simple, straight, brown, 0-2-septate, 17$21 \times 5-7 \mu \mathrm{m}$. Conidiogenous cells monoblastic, integrated, mostly terminal, cylindrical, determinate. Sarciniform conidia solitary, dry, acrogenous, smooth, sarcinately septate, slightly constricted at the septa, brown to dark brown, 11-32 $\mu \mathrm{m}$ in diameter. Few Questieriella conidia were observed, curved, fusiform, 
3-septate, slightly constrict at the septa, central cells brown, terminal cells pale, attenuated to broadly rounded at the tip, 30-34 ×9-11 $\mu \mathrm{m}$.

Material examined - India, Karnataka, South Canara, Kukke Subramanya, on leaves of Thea sinensis (L.) Kuntze (Theaceae), 15 November 2003, V.B. Hosagoudar HCIO 45784 (holotype), TBGT 1533 (isotype).

Schiffnerula camelliae (Sydow, Sydow \& Butler) Hughes is known on this host from North-East India, Kerala and Java (Hosagoudar et al. 1999). Sarcinella conidia were not known for this taxon. However, the present collection reveals only abundant Sarcinella conidia and few Questieriella conidia. The morphology of the Questieriella conidia in the present collection is different from the earlier known ones. Further, outer surface of the mycelia is undulate in Schiffnerula and is smooth and straight in the present collection.

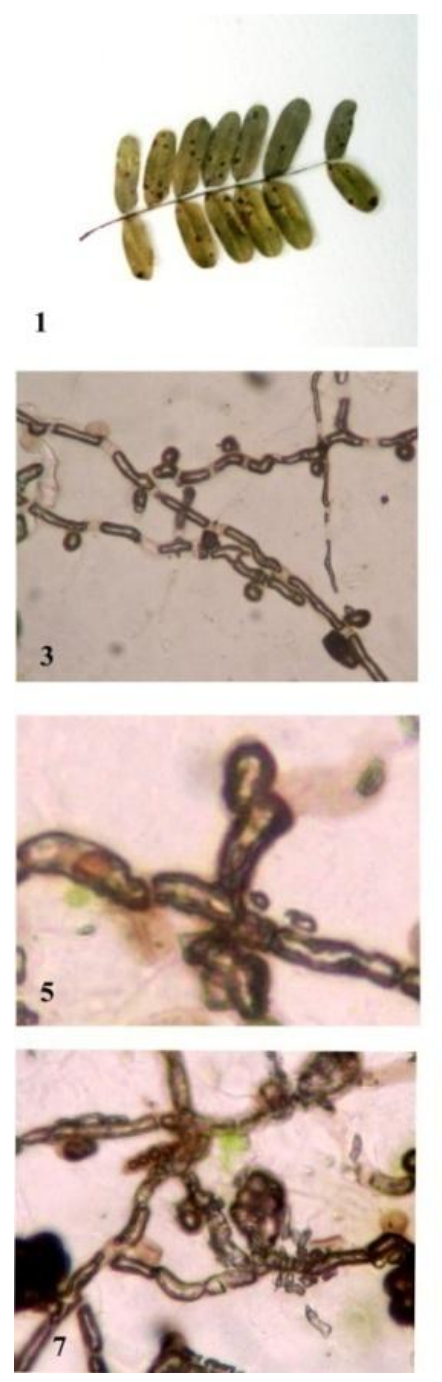

Sarcinella vitecis N. Srivastava, S. Chandra \& C. Gupta, Vegetos 3: 78, 1990.

Colonies epiphyllous, dense, confluent. Hyphae pale brown to olivaceous, alternate to oppositely branched, 4-7 $\mu \mathrm{m}$ thick. Appressoria numerous, alternate, pinkish to pale brown, clavate to mucronate, 9-15 × 6-21 $\mu \mathrm{m}$. Sarcinella conidiophores micronematous, arising laterally from the hyphae, short, simple, straight, smooth, pale brown, conidiogenous cells monoblastic, integrated, terminal, cylindrical; conidia solitary, dry, simple, smooth, subglobose to irregularly sarciniform, muriform with more or less cruciately arranged septa, dark brown to black, deeply constricted at the septa, appearing 4-12 lobed, 20-24 × 28-32 $\mu \mathrm{m}$.

India, Uttar Pradesh, Mandla, on leaves of Vitex negundo L. (Verbenaceae), November 1986, Satish Chandra GPU KRC 110, IMI 317203 (holotype).
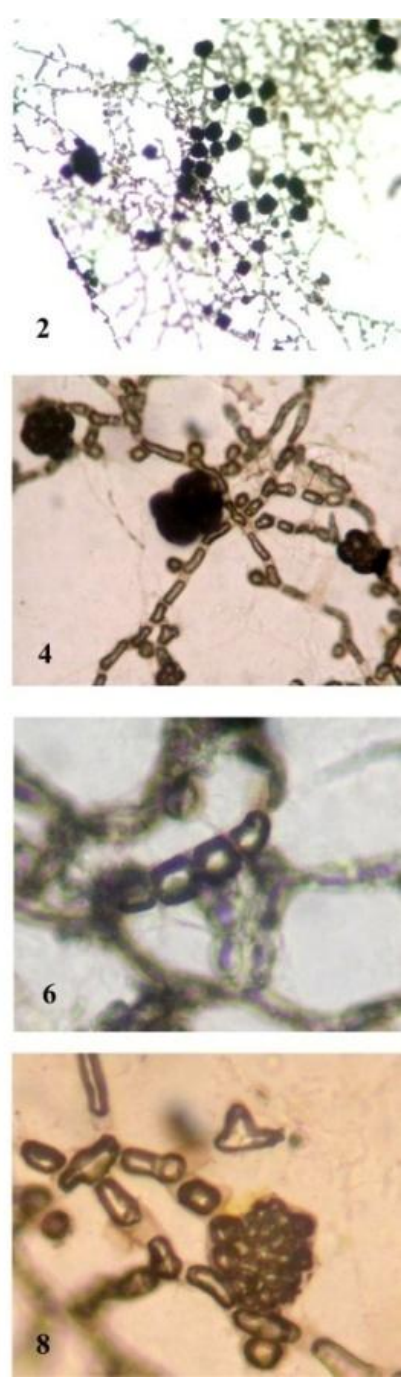

Fig. 34 - Sarcinella tamarindi, 1 Infected leaves, 2 Colony with Sarcinella conidia, 3 Appressoriate mycelium, 4 Sarcinella conidia, 5 Conidiophore, 6 Questieriella conidia, 7-8 Initials of ascoma. 
Sarcinella wrightiae Hosag., Archana, \& Agarwal, Indian Phytopath. 60: 348, 2007.

(Fig. 37)

Colonies amphigenous, subdense, up to 2 $\mathrm{mm}$ in diameter, confluent. Hyphae substraight to flexuous, branching irregular at acute to wide angles, loosely to closely reticulate, form a loose net, cells $12-24 \times 4-6 \mu \mathrm{m}$. Appressoria scattered, alternate, unicellular, globose, ovate, entire to slightly angular, 8-13 $\times 8-10 \mu \mathrm{m}$. Conidiophores micronematous, mononematous, simple, straight to curved, light brown, arise laterally from the hyphae, smooth, up to $16 \mu \mathrm{m}$ long; conidia simple, solitary, acrogenous, globose, sarciniform, dark brown, opaque, constricted at the septa, cells $3-6$ in number, $27-32 \times 16-24 \mu \mathrm{m}$.

Material examined - India, Kerala, Erumeli, Cheruvally, on leaves of Wrightia sp.
(Apocynaceae), 29 December 2005, V. Gireesh Kumar \& P.J. Robin HCIO 46993 (holotype), TBGT 2210 (isotype).

\section{The genus Schiffnerula}

Schiffnerula Hohnel, Sber, Akad. Wiss. Wien, math. Nat.kl., I, 118: 867, 1909. Arx \& Mueller, Stud. Mycol. 9: 48, 1975; Hughes, Can. J. Bot. 61: 1763, 1983. Clypeolella Hohnel, Sber. Akad. Wiss. Wien., math.nat.kl. I, 119: 403, 1910. Phaeoschiffnerula Theiss., Broteria 12: 21, 1917. Questieria Arn., Les Asterinees 1: 186, 1918. Diathrypton Sydow, Philippine J. Sci. 21: 137, 1922. Coniosporiella Bat., Atas Inst. Univ. Recife 3: 113, 1966.

Hypahe superficial, colonies foliicolous, brown, appressoriate, appressoria unicellular.

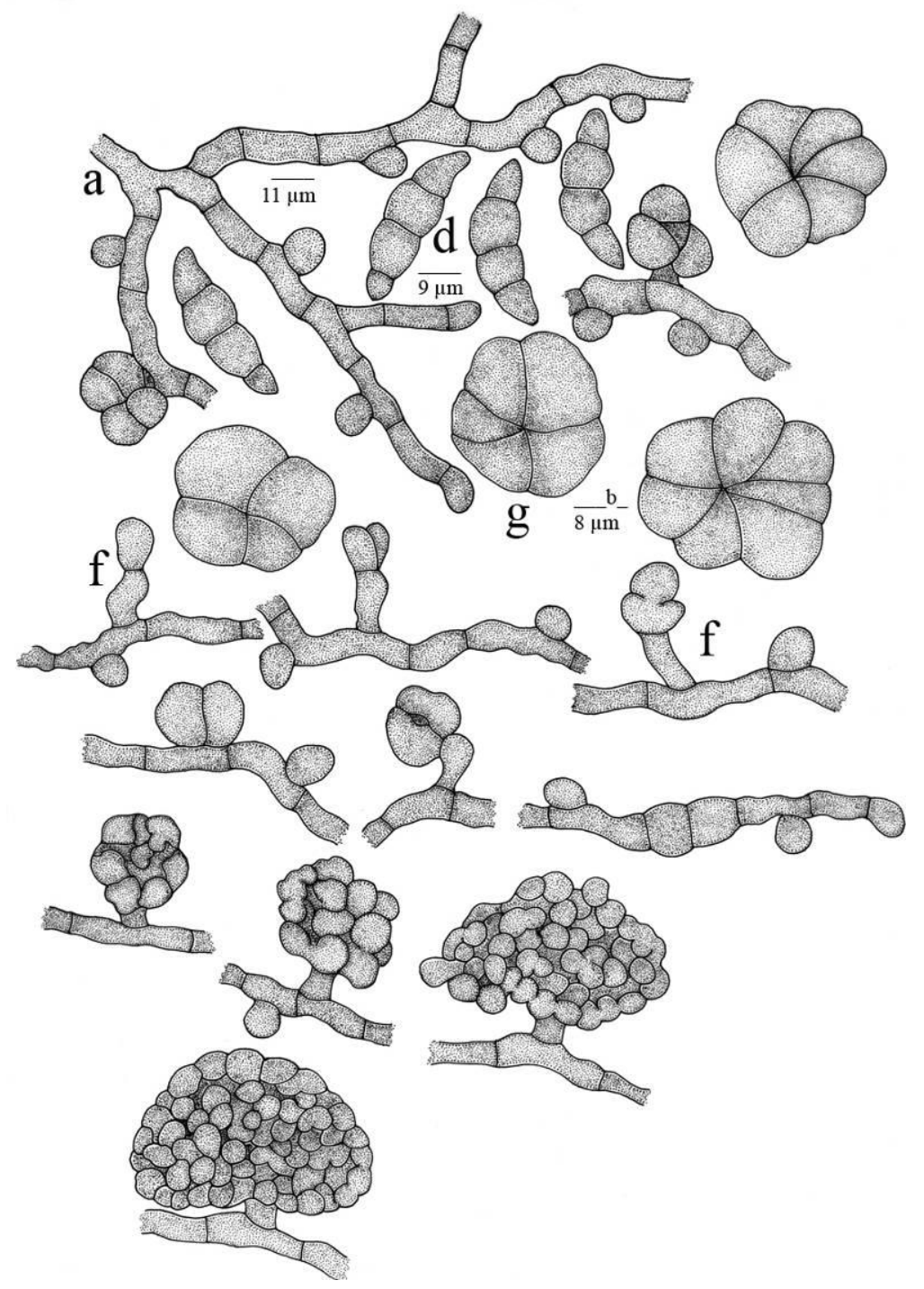

Fig. 35 - Sarcinella tamarindi 
Ascomata arise from the short lateral branches, initially with radiating cells but the cells dissolve when the ascomata start resuming globose appearance. Asci few, bitunicate, broadly ellipsoid to globose, sessile, octosporous, exposed afterdeliqusing the ascomatal wall; ascospores brown, 1-septate, constricted at the septum.

$$
\text { Type - S. mirabilis Hohnel }
$$

\section{Description of the species}

Schiffnerula actinodaphnes Hosag., Archana, Harish, Riju \& Agarwal, Indian Phytopath. 61(2): 248, 2008.

(Fig. 38)

Colonies epiphyllous, subdense, up to 2 $\mathrm{mm}$ in diameter, confluent. Hyphae substraight, branching alternate, opposite to irregular at acute to wide angles, loosely to closely reticulate, cells 9-27 × 6-8 $\mu \mathrm{m}$. Appressoria alter- nate, unilateral, globose, sessile, entire, $8-15 \times$ 8-13 $\mu \mathrm{m}$. Conidia of Questieriella scattered, pale brown, fusiform, curved, 3-septate, constricted at the septa, tapering towards both ends, $44-53 \times 11-15 \mu \mathrm{m}$. Thyriothecia few, orbicular, up to $80 \mu \mathrm{m}$ in diameter; asci not seen; ascospores oblong, conglobate, brown, uniseptate, constricted at the septum, 25-35 × 11-15 $\mu \mathrm{m}$, wall smooth.

Material examined - India, Kerala, Thiruvananthapuram, Palode, on leaves of Actinodaphne sp. (Lauraceae), 12 August 2007, G.R. Archana HCIO 48131 (holotype), TBGT 2985 (isotype).

Schiffnerula carnea (Ell. \& Mart.) Petrak is known on the members of the family Lauraceae from Africa (Hosagoudar 2003b). After examining the type, Hughes (1987) stated that it is the type species of the genus Rhytidenglerula. Hence, the present collection forms the

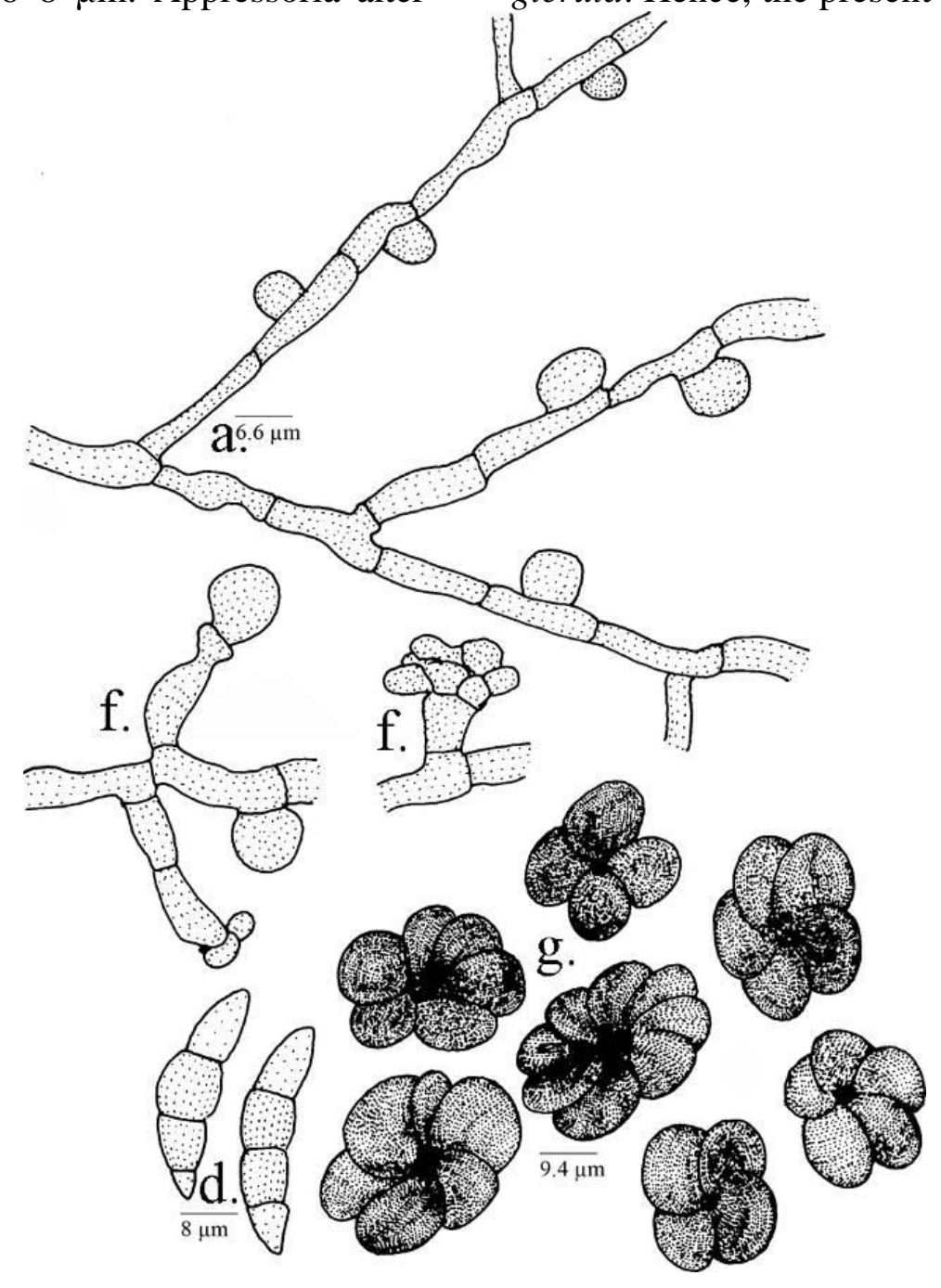

Fig. 36 - Sarcinella theae 
Plant Pathology \& Quarantine

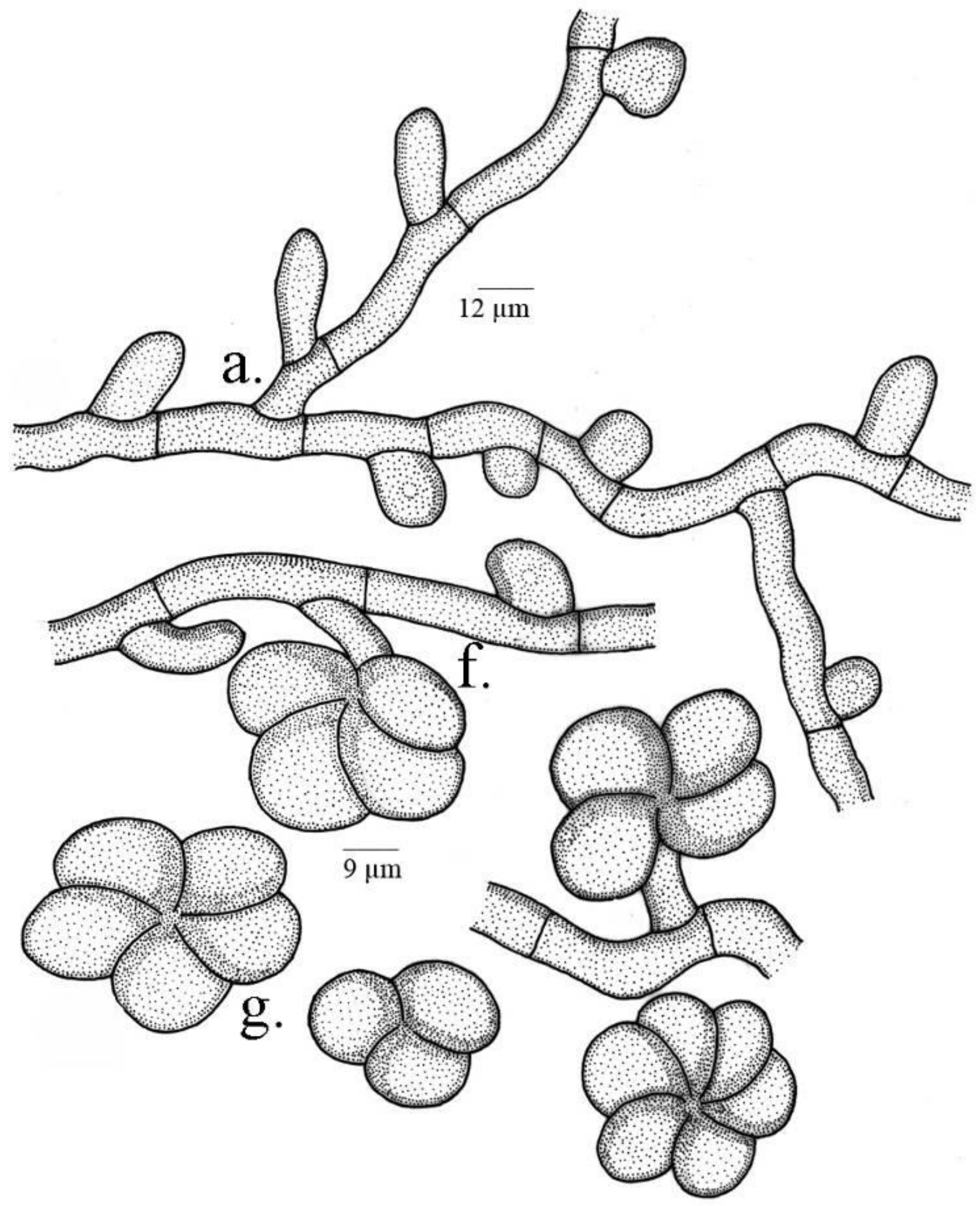

Fig. 37 - Sarcinella wrightiae 


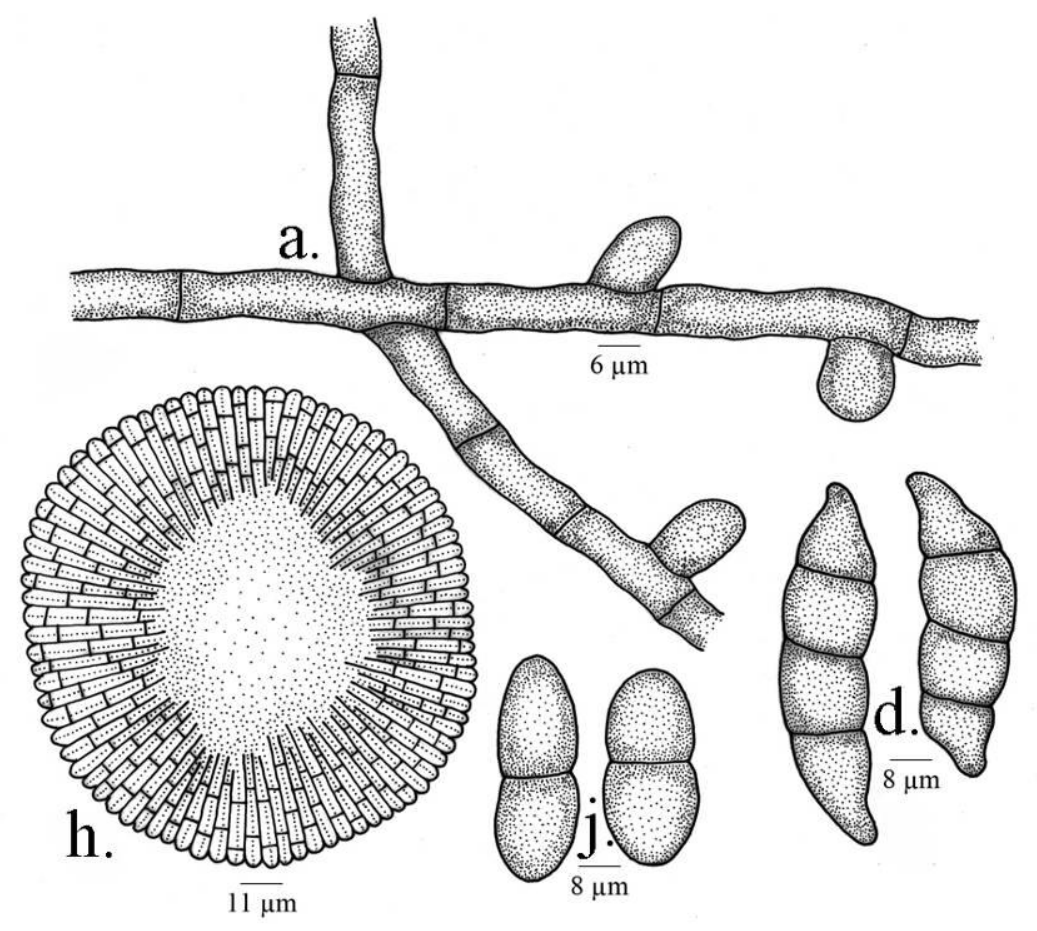

Fig. 38 - Schiffnerula actinodaphnes

first report of the genus Schiffnerula on the members of Lauraceae.

Schiffnerula azadirachtae Hosag. \& Sabeena, J. Threatened Taxa 3: 1620, 2011.

Anamorph - Sarcinella azadirachtae Meenu, Singh \& Chaudhary, J. Living World 1: 107, 1994.

(Fig. 39)

Colonies amphigenous, thin, up to $2 \mathrm{~mm}$ in diameter confluent. Hyphae brown, flexuous, branching opposite, alternate to unilateral at acute to wide angles, loosely reticulate, cells $12-35 \times 4-6 \mu \mathrm{m}$. Appressoria alternate to unilateral, globose, entire, 7-10 × 7-10 $\mu \mathrm{m}$. Conidia of Questieriella scattered in the colonies, curved, 3-septate, slightly constricted at the septa, taper towards both ends, 27-40 × 7-10 $\mu \mathrm{m}$. Sarcinella conidiophores produced lateral to the hyphae, single, straight, flexuous, mononematous; conidiogenous cells terminal, monoblastic, integrated, cylindrical. Sarcinella conidia blastic, terminal, mostly sessile, solitary, ovate to globose, sarciniform, 2-7 celled, constricted at the septa, $27-42 \mu \mathrm{m}$ in diameter, wall smooth. Thyriothecia scattered, globose, ovate, orbicular, peridial cells initially radiating, later the central portion dissolved by exposing asci, up to $70 \mu \mathrm{m}$ in diameter, marginal cells radiating; asci 2-4 per thyriothecia, octosporous, 12-
$20 \mu \mathrm{m}$ in diameter; ascospores oblong, conglobate, uniseptate, constricted at the septum, 15-20 × 7-10 $\mu \mathrm{m}$, wall smooth.

Material examined - India, Kerala, Thiruvananthapuram, Kallara, on leaves of Azadiracta indica A. Juss. (Meliaceae), 10 August 2010, A. Sabeena TBGT 4323 (holotype), isotype deposited in HCIO (isotype).

Meenu \& Chaudhary (1994) described Sarcinella azadirachtae on Azadiracta indica from Nepal. However, the teleomorph name supersedes the anamorph name.

Schiffnerula braunii Hosag. \& Sabeena, Taiwania 55(3): 251, 2010.

(Fig. 40)

Anamorph - Questieriella braunii Hosag., Abraham \& C.K. Biju, New Botanist 23: 211, 1996.

Colonies amphigenous, dense, velvety, up to $2 \mathrm{~mm}$ in diameter, confluent. Hyphae substraight to flexuous, branching opposite to unilateral at acute to wide angles, loosely to closely reticulate, cells $11-21 \times 3-6 \mu \mathrm{m}$. Appressoria alternate to unilateral, unicellular, globose, ovate, entire, 5-10 × 6-11 $\mu \mathrm{m}$. Conidia of Questieriella were solitary, curved, 3septate, slightly constricted at the septa, taper towards both ends, $25-42 \times 5-10 \mu \mathrm{m}$. Thyriothecia scattered to connate, orbicular to ovate, peridial cells initially radiating, later central 


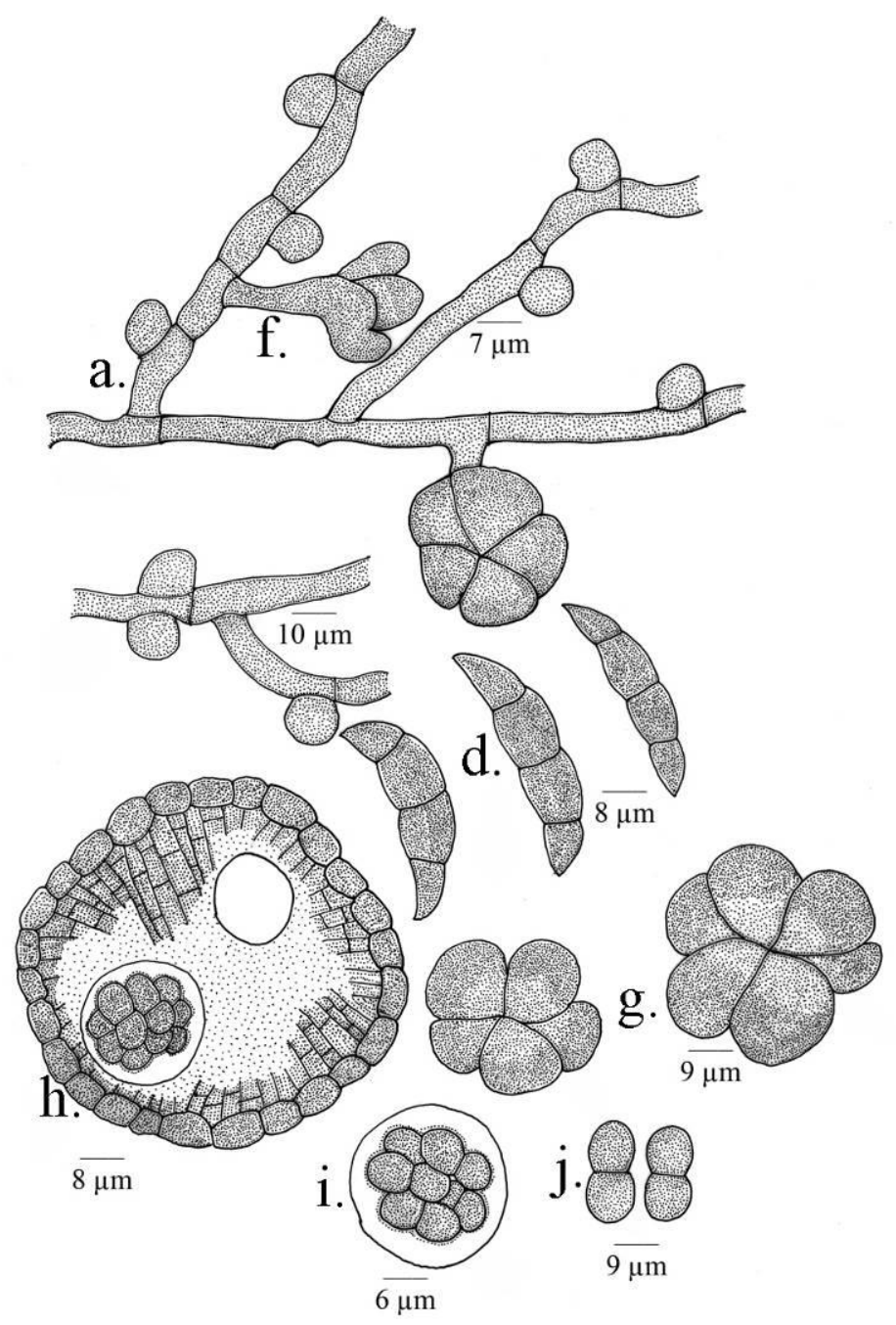

Fig. 39 - Schiffnerula azadirachtae

portion dissolved by exposing asci, up to 170 $\mu \mathrm{m}$ in diameter; asci 5-6 per thyriothecia, globose, ovate, clavate, octosporous, up to 15-25 × 18-20 $\mu \mathrm{m}$; ascospores conglobate, uniseptate, constricted at the septum, 15-20 $\times$ 5-8 $\mu \mathrm{m}$.

Material examined - India, Kerala, Thiruvananthapuram, Palode, in the campus of Tropical Botanic Garden and Research Institute, on leaves of Morinda pubescence I.E. Smith (Rubiaceae), 29 September 2008, A. Sabeena HCIO 49236 (holotype), TBGT 3475 (isotype); on leaves of Morinda pubescens I.E. Smith (M tinctoria Roxb.) (Rubiaceae), 11 December 1996, V.B. Hosagoudar HCIO 42436, TBGT 110; 19 October 2000, M. Kamarudeen HCIO 44405, TBGT 698; 5 December 2001, H. Biju HCIO 46119, TBGT 1882; 25 January 2005, Archana \& al. HCIO 46005, TBGT 1769; 12 October 2006, Sabeena \& Riju HCIO 47414, TBGT 2318; Morinda reticulata Gamble, TBGRI Campus, Palode, 1 January 2001, H. Biju HCIO 46107, TBGT1870; 12 December 2006, Sabeena \& Riju HCIO 47414, TBGT 2452; 12 October 2006, Sabeena \& Riju HCIO 47416 TBGT 2454; 17 July 2006, Sabeena \& Archana HCIO 47983; Morinda sp., Trivandrum, Eanikara, 20 January 2001, V.B. Hosagoudar HCIO 43964, TBGT 461; Thiruvananthapuram Forest area, Palode, Kusavoor, 16 November 2002, A. Manoj Kumar HCIO 44688, TBGT 969.

There are five species of the genus Schiffnerula on the members of the family Rubiaceae, namely $S$. craterispermi (Hansf.) Hughes on Craterispermum laurinum from Uganda; $S$. hendrickxii (Hansf.) Hughes on Graumiliae sp. from Congo; S. psychotriae (Doidge) Hughes on Psychotria capensis from South Africa; S. palicoureae (Fair) Hughes on Palicoureae croca from Dominica; S.ugandensis (Hansf.) Hughes on Rubiaceae member (Pavetta) from 

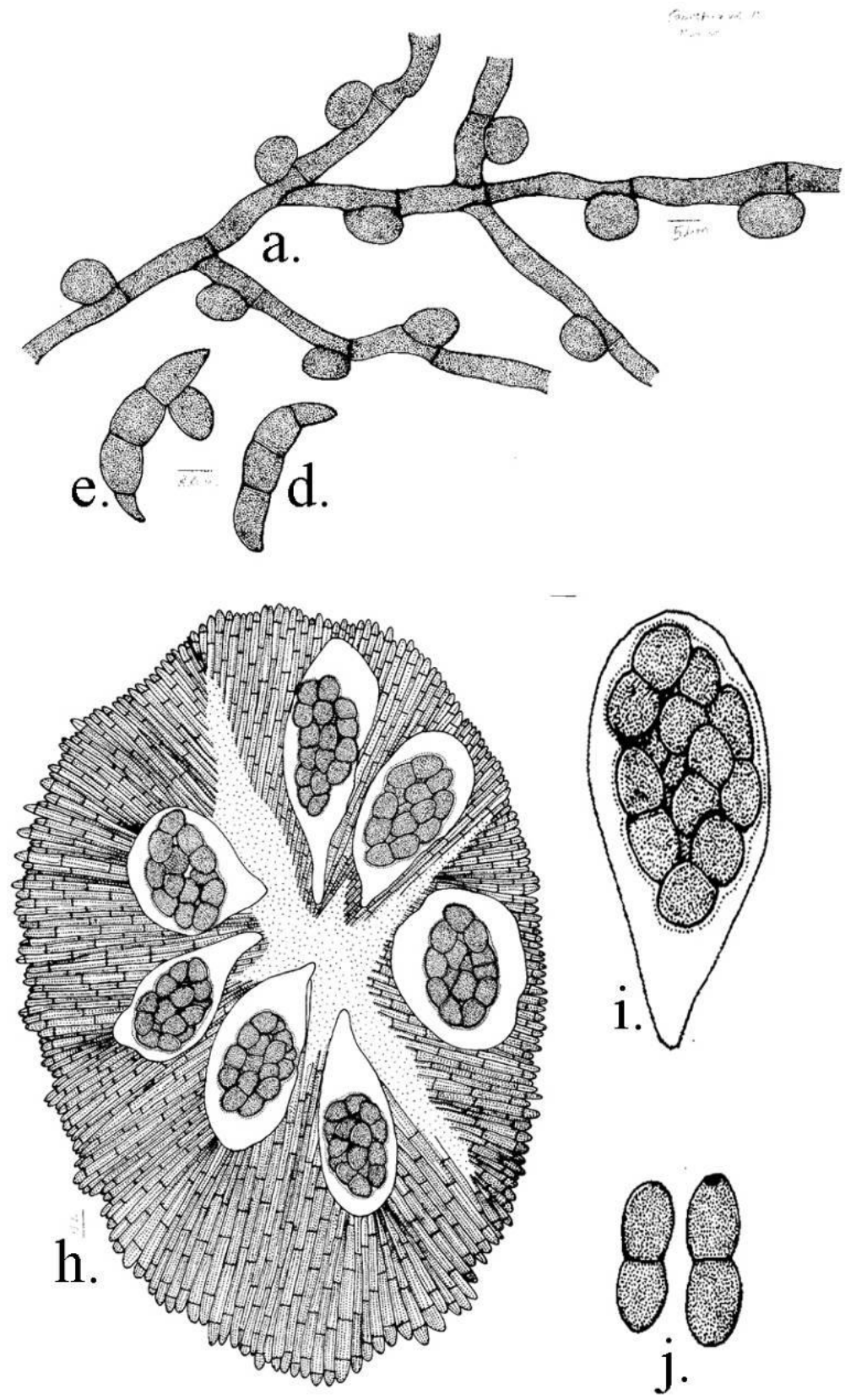

Fig. 40 - Schiffnerula braunii

Uganda (Hughes 1987) and Questieriella braunii Hosagoudar et al. on Morinda pubescens Smith from India (Hosagoudar et al. 1996). Of these, the genus Craterispermum, Grumulia and Palicourea are not represented in India (Santapau \& Henry 1971). S. braunii differs from $S$. psychotriae and $S$. ugandensis in having much narrower Questieriella conidia, smaller thyriothecia, asci and ascospores. Further, it can be distinguished from these species in having entire and globose in contrast to mammiform appressoria, attenuated towards apex, which are often sublobate (Sivanesan 1984). This species mostly persists in
Questieriella state but our efforts resulted in recording its teleomorph.

Schiffnerula brideliae Hansf., Proc. Linn. Soc. London 153(1): 12, 1941. Hosag. \& Riju, Indian J. Sci. \& Techn. 2(6): 7, 2009. (Fig. 41)

Colonies amphigenous, thin, up to $2 \mathrm{~mm}$ in diameter, confluent. Hyphae substraight to flexuous, branching opposite, alternate to unilateral at acute to wide angles, loosely reticulate, cells 13-38 × 4-7 $\mu \mathrm{m}$. Appressoria alternate, unilateral, globose, mammiform, entire, 6-13 $\times$ 6-11 $\mu \mathrm{m}$. Conidia of Questieriella scattered in the colonies, curved, 3-septate, slightly con- 


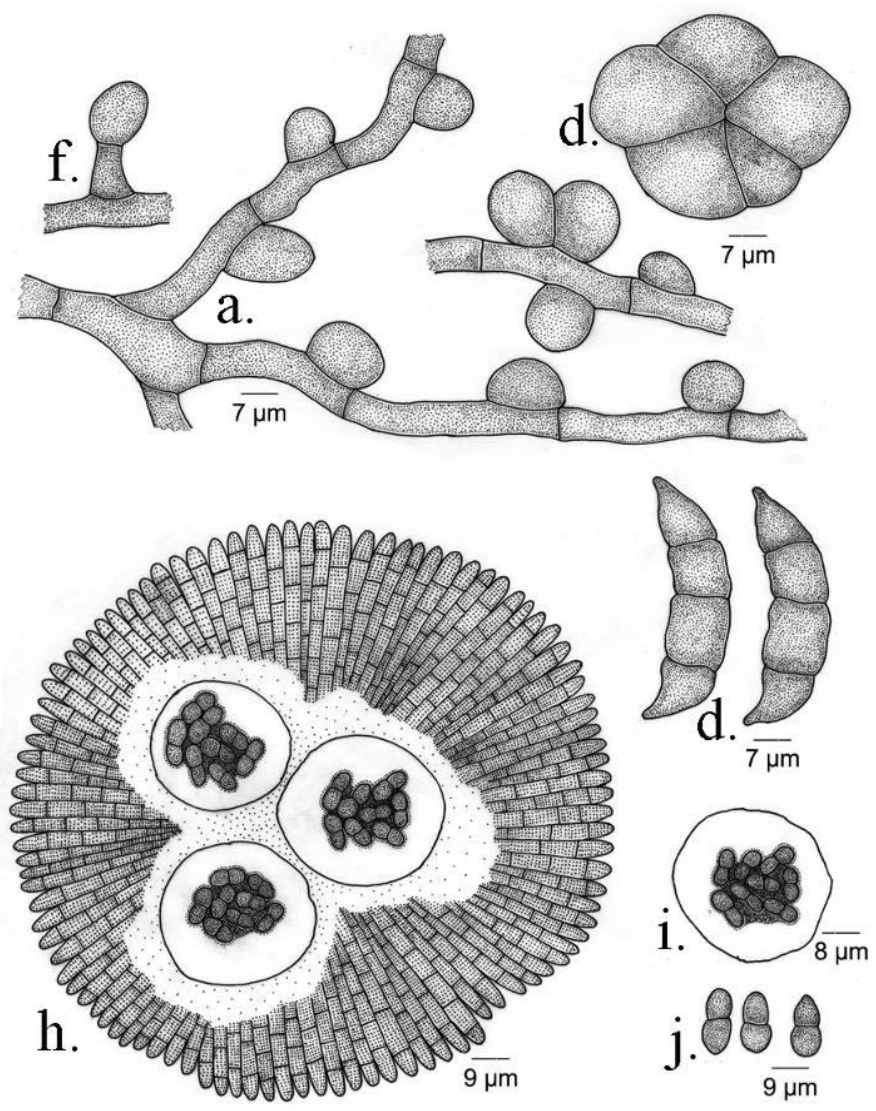

Fig. 41 - Schiffnerula brideliae

stricted at the septa, taper towards both ends, $28-30 \times 8-11 \mu \mathrm{m}$. Conidiophores of Sarcinella produced lateral to the hyphae, single, straight to flexuous, macronematous, mononematous, $0-3$ septate, 4-7 × 6-9 $\mu \mathrm{m}$; conidiogenous cells terminal, monoblastic, integrated, cylindrical; conidia blastic, terminal, mostly sessile, solitary, dry, ovate to globose, sarciniform, cruciately septate, 48 celled, constricted at the septa, 26-40 $\mu \mathrm{m}$ in diameter, wall smooth. Thyriothecia scattered, globose, ovate, peridial cells initially radiating, later central portion dissolved by exposing asci, up to $121 \mu \mathrm{m}$ in diameter; asci 3-4 per thyriothecia, globose, octosporous, bitunicate, 27-32 $\mu \mathrm{m}$ in diameter; ascospores oblong, conglobate, uniseptate, constricted at the septum, $8-13 \times 5-7 \mu \mathrm{m}$, remain hyaline for some time but turn brown at maturity, wall smooth.

Material examined - India, Kerala, Wayanad $16^{\text {th }}$ mile, Padinharathara, on leaves of Bridelia sp. (Euphorbiaceae), 10 November 2007, M. C. Riju HCIO 48169, 48172, TBGT 2905, 2908. This fungus was known on Bridelia macrantha from Uganda (Hansford 1941a, b).
Schiffnerula camelliae (Sydow, Sydow \& Butler) Hughes, Pleomorphic Fungi. The Diversity and its Taxonomic Implications, p. 133, 1987; Hosag., J. Mycopath. Res. 37: 27, 1999. Asterina camelliae Sydow, Sydow \& Butler, Ann. Mycol. 9: 389, 1911. Clypeolella camelliae (Sydow, Sydow \& Butler) Hansf., Reinwardtia 3: 127, 1954.

(Fig. 42)

Colonies epiphyllous, rarely amphigenous, caulicolous, dense, velvety, crustose, up to $5 \mathrm{~mm}$ in diameter, confluent. Hyphae straight to substraight, outer surface tubercled to crenulated, branching alternate, opposite to irregular at acute to wide angles, loosely to closely reticulate, cells $32-40 \times 7-9 \mu \mathrm{m}$. Appressoria scattered, alternate, unilateral, globose, oval, broad based, unicellular, entire, crenulated to rarely sublobate, $12-18 \times 14-16 \mu \mathrm{m}$. Questieriella type of conidia were few, fusiform, curved, 3-septate, central cells darker, distal cells paler, attenuated towards the tip and acute to obtusely rounded at the apices, 80-93 $\times 9-10 \mu \mathrm{m}$. Thyriothecia scattered to connate, dimidiate, orbicular, up to $150 \mu \mathrm{m}$ in diameter, spreading marginally, dehisce stellately and dissolve at the centre; asci many, 


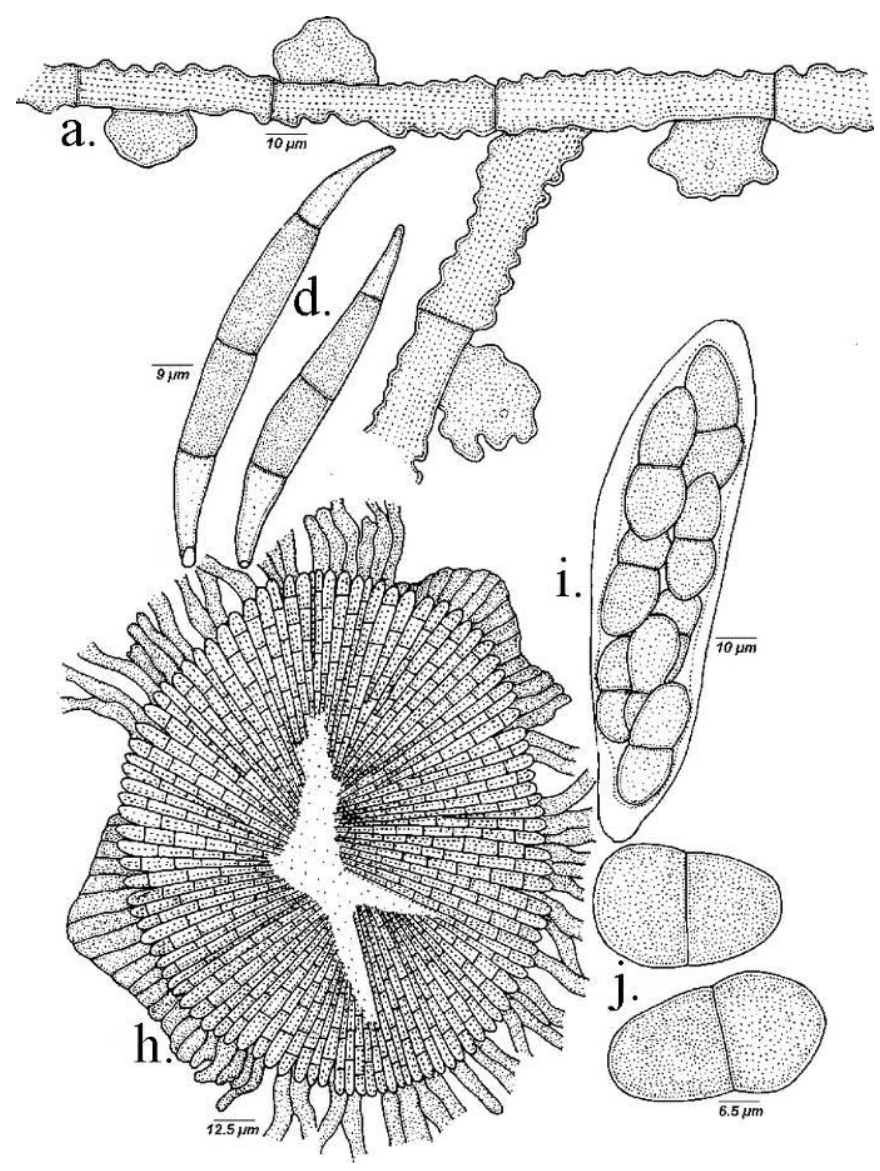

Fig. 42 - Schiffnerula camelliae

cylindrical, octosporous, $100-120 \times 30-35 \mu \mathrm{m}$, sessile; ascospores biseriate, 1-septate, brownish, upper cell smaller and globose, lower cell oval and slightly attenuated, $30-37 \times 15-17$ $\mu \mathrm{m}$, wall smooth.

Material examined - India, Kerala, Thiruvananthapuram, Athirumala, 26 March 1996, on leaves of Thea sinensis (L.) Kuntze (Theaceae), V.B. Hosagoudar HCIO 44138, TBGT 516; Idukki, Munnar, Devikulam, 23 January 2003, A. Manoj Kumar \& H. Biju HCIO 44857, TBGT 44; Rajamala, 30 June 1998, C.K.Biju TBGT 208; Mattupetty, 24 January, 2003, H. Biju \& A. Manoj Kumar HCIO 44822, TBGT 1059; HCIO 44824, TBGT 1061; Nalpathanchushola, 22 January 2003, H. Biju \& A. Manoj Kumar HCIO 44825, TBGT 1062; Gravel banks, Rajamala, 20 January 2003, H. Biju \& A. Manoj Kumar HCIO 44826, TBGT 1063; Anaimudy tea estate, 20 January 2003, H. Biju \& A. Manoj Kumar HCIO 44830, TBGT 1067; Rajamala, 20 January 2003, H. Biju \& A. Manoj Kumar HCIO 44834, TBGT 1071; Thiruvananthapuram, near Chemunji hills, Bonaccord estate, 11
March 1997, V.B. Hosagoudar ILL, TBGT 186; Bonacaud Estate, 7 December 2001, G. Rajkumar HCIO 45092, TBGT 1147; 22 March 2001, G. Rajkumar HCIO 47400, TBGT 2438; Idukki, Thekkadi Anchurly, Periyar Tiger Reserve, 21 March 2006, H. Biju \& V. Gireesh Kumar HCIO 47625, TBGT 2647; Thiruvananthapuram, Ponmudi, 22 February 2007, G.R. Archana. \& al HCIO 47997, TBGT 2780; HCIO 48001, TBGT 2784; HCIO 48009, TBGT 2792; Idukki, Kuttikanam, 17 March 2007, Harish \& al HCIO 48319, TBGT 3040; Thiruvanthapuram, Peppara, 19 March 2009, Jacob Thomas \& al HCIO 49514, TBGT 3756; Athirumala, 28 February 2008, Jacob Thomas \& al HCIO 49516, TBGT 3758; Palghat, Silent Vally National Park, 3 March 2009, Shaji \& al HCIO 49549, TBGT 3791; Thiruvananthapuram, Pongalapara, Neyyar Wildlife Sanctuary, 4 March 2009, Jacob Thomas HCIO 49579, TBGT 3821; Kottayam, Placherry, 23 April 2008, P.J. Robin HCIO 49906, TBGT 4058; Ponmudi, 7 March 2008, V. B. Hosagoudar \& al TBGT 4239; Wayanad, Periya, 5 November 2009, M.C. Riju \& A. 
Sabeena TBGT 4737, 4739, 4741; Palghat, Silent valley, Valakkad, 5 August 2008, M.C. Riju \& al TBGT 5237.

Sydow et al. (1911) described this taxon as Asterina camelliae, collected from Assam by G. Watt in 1895 . Based on the collections from Java, Hansford (1954) transferred it to the genus Clypeolella. However, Hughes (1987) treated the genus Clypeolella as synonymous to Schiffnerula. Yamamoto (1957) has described Asterina theae from Taiwan and the mycelium is crenulated. It appears to be related to the present taxon. Katumoto (1975) has reported this species and has given a detail history of this species.

In India, this fungus occurs in Assam and in the souther Western Ghats of Peninsular India.

Schiffnerula canthii Hosag. \& Archana, J. Threatened Taxa 1(7): 378, $2000 . \quad$ (Fig. 43)

Colonies amphigenous, subdense, up to 2 $\mathrm{mm}$ in diameter, confluent. Hyphae flexuous, branching opposite, alternate to irregular at acute to wide angles, loosely to closely retculate, cells $11-27 \times 6-8 \mu \mathrm{m}$. Appressoria alternate, unilateral, globose, sessile, entire, 9-15 $\times$ 8-15 $\mu \mathrm{m}$. Conidia of Questieriella scattered, pale brown, fusiform, curved, 3-septate, constricted at the septa, tapering towards both ends, $40-48 \times 11-15 \mu \mathrm{m}$. Sarcinella conidiophores micronematous, simple, branched, straight to flexuous, pale brown, 0-2-septate, $12-40 \times 5-8 \mu \mathrm{m}$; conidiogenous cells monoblastic, integrated, mostly terminal, cylindrical; conidia solitary, dry, simple, subspherical to sarciniform, 2-8-celled, brown when young, carbonaceous black at maturity, sarcinately septate, constricted at the septa, 20-40 $\mu \mathrm{m}$ in diameter, wall smooth. Thyriothecia few, orbicular, up to $75 \mu \mathrm{m}$ in diameter; asci not seen; ascospores oblong, conglobate, brown, uniseptate, constricted at the septum, 22-26 $\times$ 8-13 $\mu \mathrm{m}$, wall smooth.

Material examined - India, Kerala, Thiruvananthapuram, Ponmudi, on leaves of Canthium sp. (Rubiaceae), 20 February 2007, G.R. Archana \& al HCIO 48164 (holotype), TBGT 2900 (isotype).

Schiffnerula craterispermi (Hansf.) Hughes, S. hendrickxii (Hansf.) Hughes, S. psychotriae (Doidge) Hughes, S. palicoureae
(Farr.) Hughes and S. ugandensis (Hansf.) Hughes are known on different host genera of the family Rubiaceae (Hosagoudar 2003b). So far there is no record of the genus Schiffnerula on the host genus Canthium. Based on the host specificity, the present fungus has been accommodated in this species.

Schiffnerula cassiae Hansf., Proc. Linn. Soc. London 160: 151, 1949; Sahni, Mycopath. Mycol. appl. 23: 334, 1964.

Stat. - Sarcinella \& Questieriella

Colonies foliicolous, amphigenous, thin, up to $5 \mathrm{~mm}$ in diameter, rarely confluent. Hyphae straight to substraight, brown to dark oliveceous, branching irregular at acute angles loosely reticulate. Appressoria scattered, ovate, globose to mammiform, entire to rarely angular. Sarcinella conidiophores short, erect; conidia subspherical, sarciniform, brown to oliveceous brown, 5-6-celled, sarcinately arranged, strongly constricted at the septa, $23-34 \mu \mathrm{m}$ in diameter, wall smooth. Questieriella conidia falcate, 3-septate, pointed at both ends, 17-34 $\times 7-10 \mu \mathrm{m}$.

India, Madhya Pradesh, Gwarighat, on leaves of Bauhinia variegata L. (Caesalpiniaceae), September 1962, Sahni IMI 96675.

Schiffnerula catharanthi Hosag. \& Archana, J. Sci. Trans. Technov. 4: 89, 2010. (Fig. 44) Anamorph - Sarcinella catharanthi Hosag. \& H. Biju, J. Econ. Taxon. Bot. 28: 198, 2004.

Colonies epiphyllous, dense, up to $4 \mathrm{~mm}$ in diameter, confluent. Hyphae substraight to flexuous, branching opposite, alternate to irregular at acute to wide angles, loosely to closely reticulate, cells $11-21 \times 3-7 \mu \mathrm{m}$. Appressoria alternate, opposite, unilateral, globose, ovate, entire, 6-12 × 6-10 $\mu \mathrm{m}$. Questieriella conidia mostly detached, scattered in the colonies, germinating, pale yellow, ellipsoidal, curved, 3septate, attenuated at both ends, acute to broadly rounded at the tip, 28-35 $\times 8-12 \mu \mathrm{m}$. Sarcinella type of conidia borne on conidiophores, conidiophores produced laterally from the hyphae, simple, straight, flexuous to curved, 0 3-septate, 9-24 × 6-8 $\mu \mathrm{m}$; conidiogenous cells integrated, mostly terminal, often intercalary, straight to curved, pale yellow, monoblastic, 


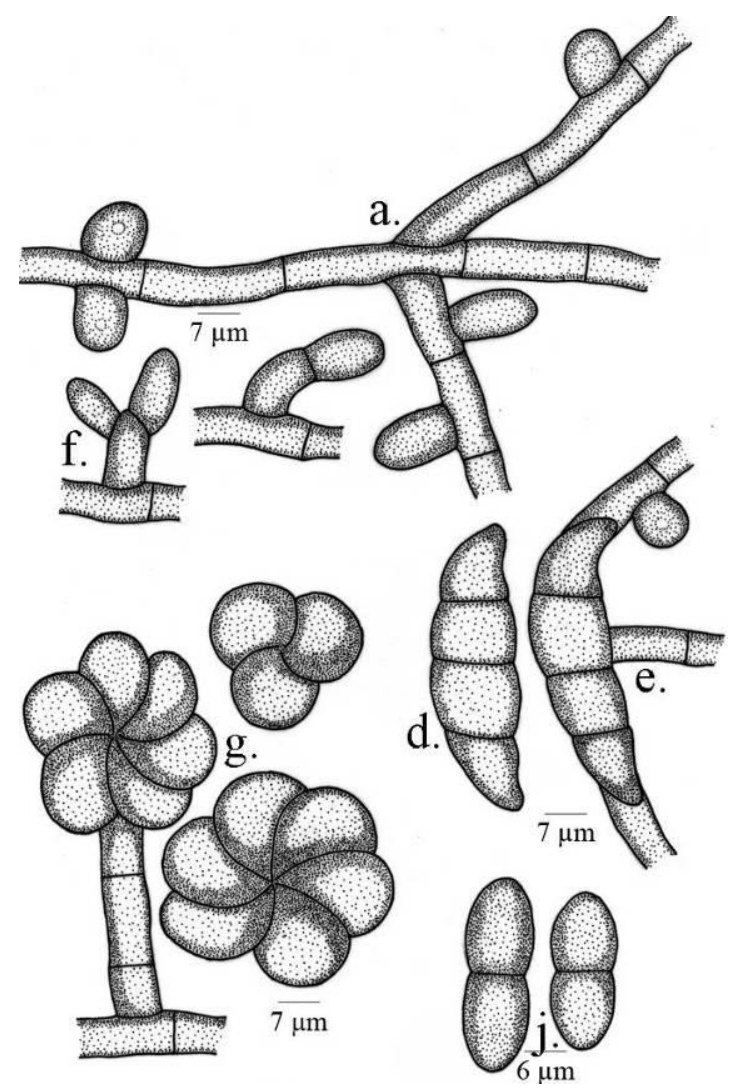

Fig. 43 - Schiffnerula canthii

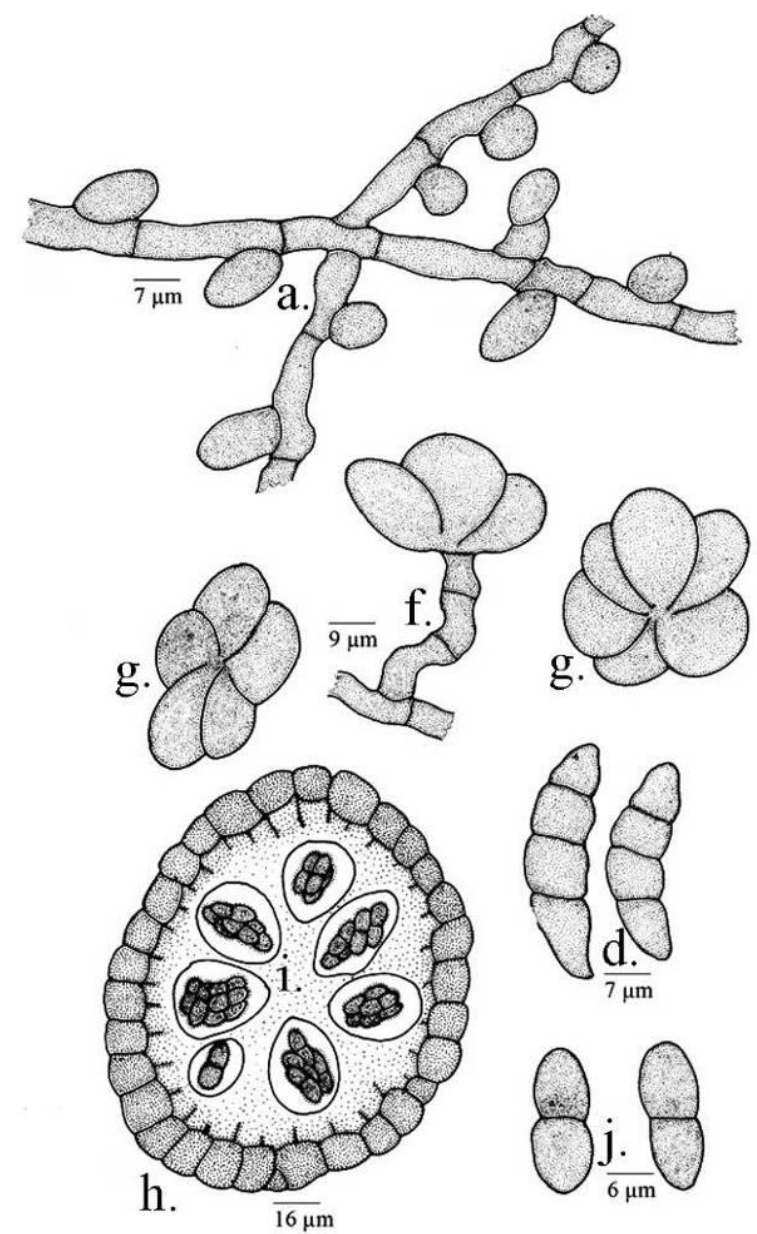

Fig. 44 - Schiffnerula catharanthi 
determinate; conidia simple, solitary, acrogenous, smooth, sarciniform, 2-8 celled, constricted at the septa, charcoal black, 25-32 $\times$ 20-29 $\mu \mathrm{m}$. Thyriothecia scattered to grouped, orbicular, up to $85 \mu \mathrm{m}$ in diameter; asci ovate, clavate, octosporous, 19-25 × 20-26 $\mu \mathrm{m}$; ascospores oblong, conglobate, brown, uniseptate, constricted at the septum, 17-24 × 6-11 $\mu \mathrm{m}$, wall smooth.

Material examined - India, Kerala, Thiruvananthapuram, Palode, Karimancode, on leaves of Catharanthus roseus (L.) G. Don (Apocynaceae), 21 January 2008, G.R. Anjana HCIO 49290 (holotype), TBGT 3535 (Isotype); Palode, TBGRI Campus, 8 August 2001, H. Biju HCIO 44135 (holoype of anamorph), TBGT 514 (isotype of anamorph); Thiruvananthapuram, Palode, TBGRI Campus, 3 October 2005, M. Unnikrishnan. HCIO 46736, TBGT 2077; Karnataka, Coorg, Hakathur, 28 November 2008, V.B.Hosagoudar \& al. HCIO 49081, TBGT 3336.

Schiffnerula celastri Hosag., Riju \& Sabeena, Indian J. Sci. Techn. 2(6): 8, 2009. Stigmella palawanensis Sydow, Philippine J. Sci. 9: 189, 1914; Sahni, Mycopath. Mycol. Appl. 23: 332, 1964. Sarcinella palawanensis (Sydow \& Sydow) Sahni, Mycopath. Mycol. Appl. 29: 241, 1966. Sarcinella paniculatae Verma, Tripathi \& R. K. Choudhary, Indian Phytopath. 52: 379, 1999. Clypeolella inversa Hohn sensu Thite \& Kulkarni, Indian Phytopath. 26: 76, 1973.

(Figs 45-46)

Colonies amphigenous, up to $4 \mathrm{~mm}$ in diameter, confluent. Hyphae substraight to flexuous, branching opposite, alternate to unilateral at acute to wide angles, loosely reticulate, cells $13-35 \times 3-4 \mu \mathrm{m}$. Appressoria opposite, globose, mammiform, entire, 3-6 × 6-9 $\mu \mathrm{m}$. Conidia of Questieriella were scattered, not attached, curved, 3-septate, slightly constricted at the septa, taper towards both ends, 33-55 $\times$ 6-9 $\mu \mathrm{m}$. Sarcinella conidiophores produced lateral to the hyphae, single, straight to flexuous, macronematous, mononematous, 0-2 septate, $11-31 \times 4-6 \mu \mathrm{m}$. Conidiogenous cells terminal, monoblastic, integrated, cylindrical. Sarcinella conidia blastic, terminal, mostly sessile, solitary, dry, ovate to globose, sarciniform, cruciately septate,
2-8 celled, constricted at the septa, 13-26 $\mu \mathrm{m}$ in diameter, wall smooth. Thyriothecia scattered, orbicular, ovate, initially radiating, later central portion dissolved by exposing asci, up to $174 \mu \mathrm{m}$ in diameter, marginal cells radiating; asci 5-8 per thyriothecia, globose, octosporous, bitunicate, $15-28 \mu \mathrm{m}$ in diameter; ascospores oblong, conglobate, uniseptate, constricted at the septum, 17-26 × 6$13 \mu \mathrm{m}$, remain hyaline for some time but turn brown at maturity.

Material examined - India, Kerala, Wayanad, Padinharathara, on leaves of Celastrus paniculatus Willd. (Celastraceae), 16 March 2007, M.C. Riju HCIO 48181 (holoype), TBGT 2917 (isotype); Munnar, Rajamala, 13 May 1999, C.K.Biju HCIO 44139, TBGT 540; Munnar, 18 December 2001, S.Shiburaj HCIO 44409, TBGT 635; Munnar, Mannvan shola, 21 January 2003, A. Manojkumar \& H. Biju HCIO 45219, TBGT 1256; Wyanad, Padinjarethara, 30 September 2007, M.C. Riju HCIO 48229, TBGT 2966; Padinjarethara, 23 January 2008, M.C. Riju HCIO 48230, TBGT 2968; Uttar Pradesh, Katarnia Ghat, M.A. Nomani TBGT 3506; Maharashtra, Pateghar, 3 January 2009, V.B.Hosagoudar \& al HCIO 49340, TBGT 3585; TBGT 4218; Kerala, Wyanad, Mepadi, on the way to Chungattara, 8 December 2009, Sam P. Mathew TBGT 4303; Wayanad, Padinharathara, 6 November 2009, A. Sabeena \& M.C. Riju TBGT 4667; Karnataka, Kodagu, Madikeri hill top, 26 November 2008, Jagath Thimmaiah TBGT 5372.

Sydow \& Sydow (1914) collected a fungus on this host in Philippines having fusoid 3septate conidia and named it as Stigmella palawanensis Sydow. Subsequently, Sahni (1964) located this fungus in India. Later, Sahni (1966) transferred this fungus to the genus Sarcinella as Sarcinella palawanensis (Sydow) Sahni. Verma et al. (1999) described the same fungus as $S$. paniculatae. Our recent collection revealed both anamorphs (Quistieriella and Sarcinella) and telomorph states.

Schiffnerula cryptolepidis (Patil \& Thite) Hughes, Pleomorphy in some hyphopodiate fungi, p. 133, 1987. Clypeolella cryptolepidis Patil \& Thite, M.V.M. Patrika 9: 104, 1974 (cryptolepidae). 


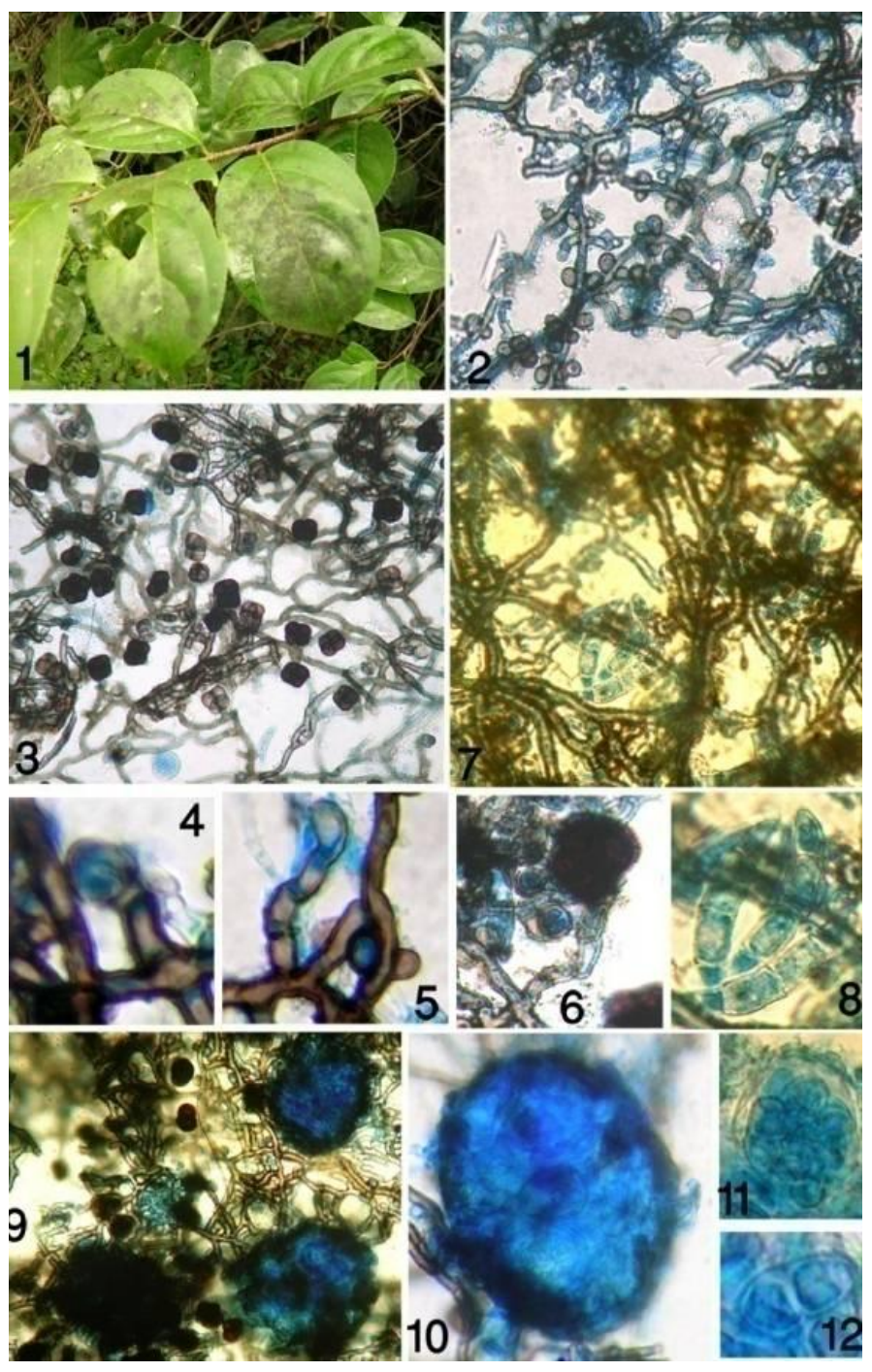

Fig. 45 - Schiffnerula celastri, 1 Infected leaves, 2 Appressoriate mycelium, 3 Sarciniform conidia, 4-6 Developing sarciniform conida, 7 Scattered conidia of Questieriella, 8 Spores of Questieriella, 9-10 Thyriothecia with exposed asci, 11 Ascus, 12 Ascospore.

Anamorph - Sarcinella crytolepidis Pande, M.V.M. Patrika 13: 1, 1978 (cryptolepidae).

Colonies amphigenous, thin to dense, up to $2 \mathrm{~mm}$ in diameter, confluent. Hyphae substraight to flexuous, branching opposite to unilateral at acute to wide angles, cells $15-20 \times$ 5-6 $\mu \mathrm{m}$. Appressoria alternate to unilateral, oval to elliptical, $10-13 \times 9-11 \mu \mathrm{m}$. Conidia of Questieriella scattered, not attached, slightly curved, 3-septate, slightly constricted at the septa, germinate to form colonies, light brown, 30-55 × 8-10 $\mu \mathrm{m}$. Sarcinella conidia borne on a short pedicels, conidia 5-6-celled, sarciniform, black, constricted at the septa, 25-30 $\mu \mathrm{m}$ in diameter. Thyriothecia orbicular, mucus diffluent at maturity, up to $85 \mu \mathrm{m}$ in diameter; asci few to many, aparaphysate, subglobose to broadly ellipsoidal, sessile, 8-spored, 40-54 × 23-26 $\mu \mathrm{m}$; ascospores brown, uniseptate, brown, constricted at the septum, 20-22 × 8-10 $\mu \mathrm{m}$, rounded at both ends, wall smooth.

India, Maharashtra, Panhala, on leaves of Cryptolepis buchanani R. \& S. (Periplocaceae), 4 July 1974, M.S. Patil Herb. Bot. Dept. Kolhapur no. 380.

Schiffnerula cryptostegiae Hosag. \& JacobThomas, sp. nov.

(Figs 47-48)

Coloniae amphigenae, densae, velutinae, ad $2 \mathrm{~mm}$ diameter, confluentes. Hyphae leniter brunneae, subrectae vel flexuosae, irregularriter acuteque vel laxe ramosae, laxe vel arte reticulatae, cellulae 14-22 × 4-6 $\mu \mathrm{m}$. Appressoria alternata vel unilateralis, unicellularis, 


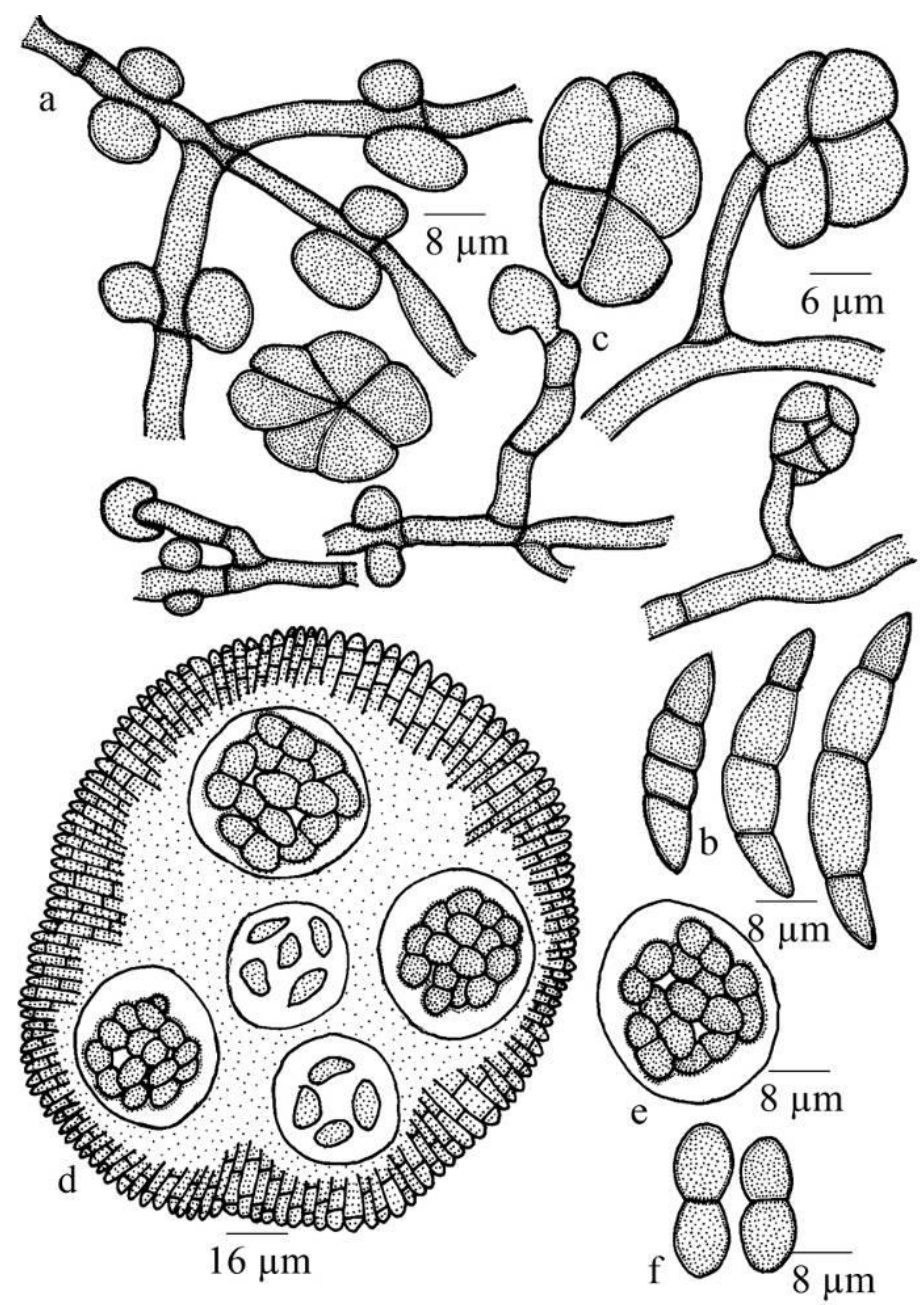

Fig. 46 - Schiffnerula celastri

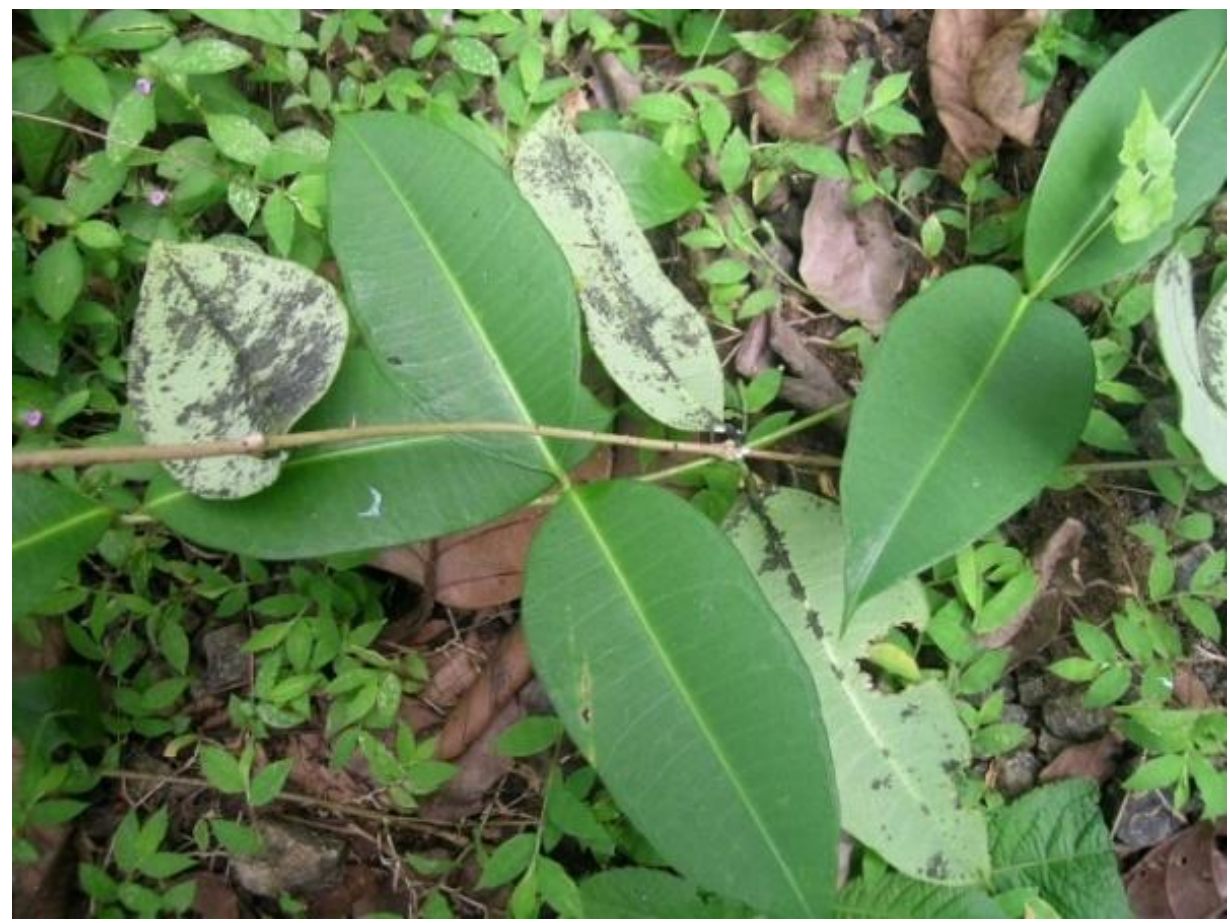

Fig. 47 - Schiffnerula cryptostegiae 


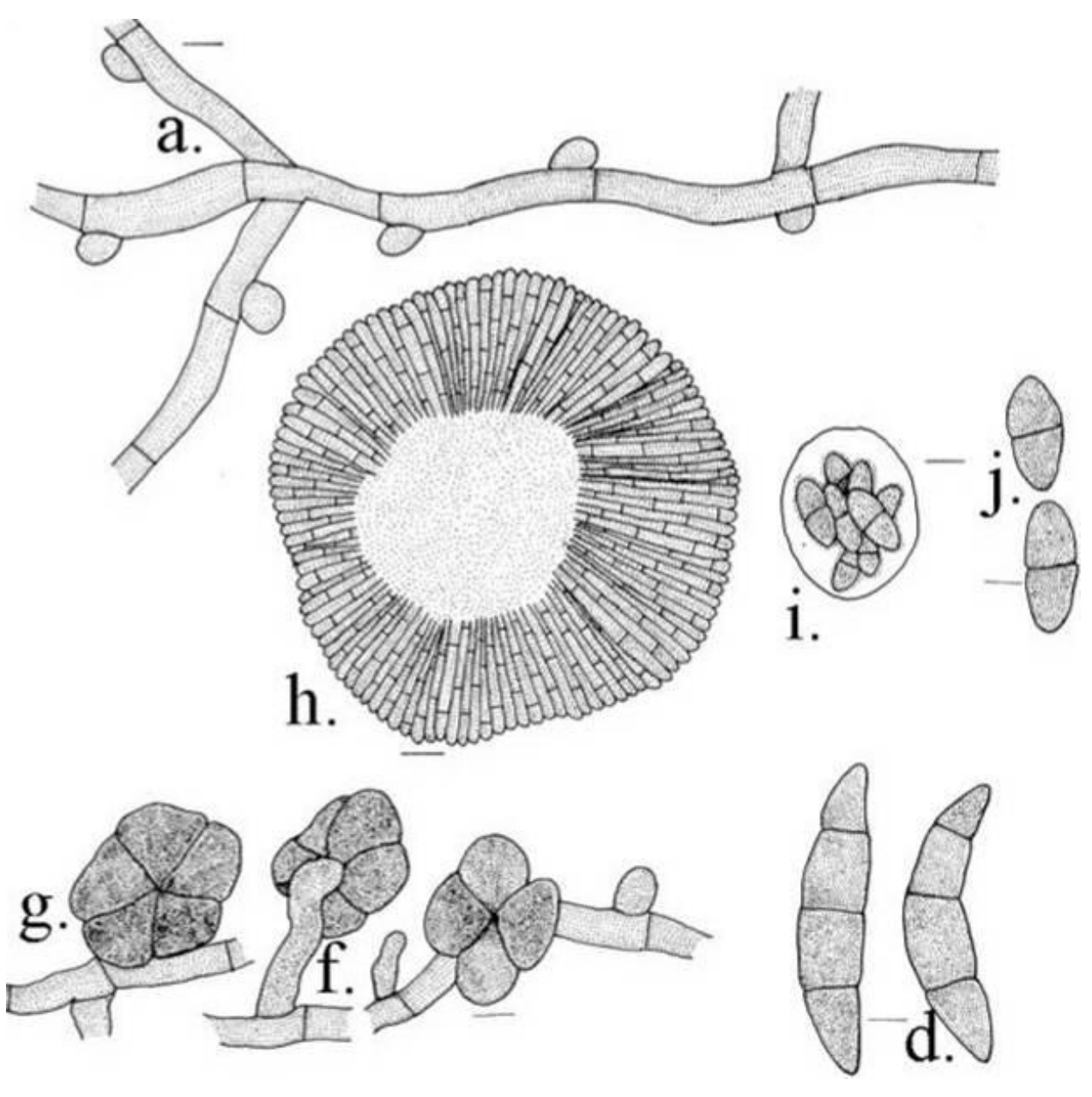

Fig. 48 - Schiffnerula cryptostegiae

globosa vel mammiformes, integra, 7-12 × 7-10 $\mu \mathrm{m}$. Conidiophorae macronematae, mononematae, simplices, rectae, leniter brunneae, producentes hyphiis lateralis, 1-3 cellulae, glabrae, 9-17 × 4-10 $\mu \mathrm{m}$; cellulae conidiogenae integratae, terminalis, monoblasticae, determinatae, cylindraceae; conidia simplices, solitaris, sicca, acrogena, globosa vel leniter ovalis, glabra, fortiter brunnea vel nigra, constrictus ad septatis, 4-6 cellula, sarciniformes, 24-29 × 19-34 $\mu \mathrm{m}$. Conidia Questieriella leniter curvula, 3-septata, constrictus ad septata, cellulae terminalis acutae, 33-36 × 11-12 $\mu \mathrm{m}$. Thyriothecia pauca, orbicularis, ad initio radiatus, portionio centralis dissolute ad maturitata et asci exposus, ad $76 \mu \mathrm{m}$ diameter; asci pauci, ovati vel subglobosi, octospori, ad $36 \mu \mathrm{m}$ diameter; ascosporae oblongae, conglobatae, uniseptatae, constrictus ad septatus, brunneae, 19-29 $\times$ 7-10 $\mu \mathrm{m}$, parietus glabrus.

Colonies amphigenous, dense, velvety, up to $2 \mathrm{~mm}$ in diameter, confluent. Hyphae light brown, substraight to flexuous, branching 180 irregular at acute to wide angles, loosely to closely reticulate, cells $14-22 \times 4-6 \mu \mathrm{m}$. Appressoria alternate to unilateral, unicellular, globose to mammiform, entire, 7-12 × 7-10 $\mu \mathrm{m}$. Conidiophores macronematous, mononematous, simple, straight, light brown, arise laterally from the hyphae, 1-3 celled, smooth, 9-17 × 4-10 $\mu \mathrm{m}$; conidiogenous cells integrated, terminal, monoblastic, determinate, cylindrical; conidia simple, solitary, dry, acrogenous, globose to slightly oval, smooth, deep brown to carbonaceous black, constricted at the septa, 4-6 celled, sarciniform, 24-29 × 19-34 $\mu \mathrm{m}$. Conidia of Questeriella present, slightly curved, 3septate, constricted at the septa, end cells acute, 33-36 × 11-12 $\mu \mathrm{m}$. Thyriothecia few, orbicular, initially radiating, later central portion dissolved by exposing the asci, upto $76 \mu \mathrm{m}$ in diameter; asci few, ovate to subglobose, octosporous, up to $36 \mu \mathrm{m}$ in diameter; ascospores oblong, conglobate, uniseptate, constricted at the septum, brown, 19-28 $\times 7-9$ $\mu \mathrm{m}$, wall smooth. 
Material examined - India, Kerala, Thrissur, Vazhachal Forests, on leaves of Cryptostegia sp. (Asclepiadaceae), 21 August 2007, Jacob Thomas \& al. HCIO 49562 (holotype), TBGT 3804 (isotype).

Sarcinella state of this fungus was known from Uttar Pradesh.

Schiffnerula ecliptae Hosag., Sabeena \& Riju, Indian Phytopath. 63: 321, 2010. (Figs 49-51)

Colonies amphigenous, thin, up to $2 \mathrm{~mm}$ in diameter, confluent. Hyphae substraight to flexuous, branching opposite to unilateral at acute to wide angles, cells $15-32 \times 5-7 \mu \mathrm{m}$. Appressoria alternate to unilateral, globose, broad based, ovate, entire, unicellular, 7-12 × 7-16 $\mu \mathrm{m}$. Conidia of Questieriella scattered, not attached, slightly curved, 3-septate, slightly constricted at the septa, germinate to form colonies, light brown, 15-30 × 10-15 $\mu \mathrm{m}$. Thyriothecia scattered, orbicular, often connate, peridial cells initially radiating, later central portion dissolved by exposing asci, 35-75 $\mu \mathrm{m}$ in diameter, marginal cells radiating; asci 1-3 per thyriothecia, globose, ovate, octosporous, $15-35 \mu \mathrm{m}$ in diameter; ascospores conglobate, uniseptate, constricted at the septum, $17-25 \times 7-12 \mu \mathrm{m}$.

Material examined - India, Kerala, Thiruvananthapuram, Palode, TBGRI Campus, on leaves of Eclipta alba (L) Hassk. (Asteraceae), 15 October 2008, A. Sabeena HCIO 49046 (holotype), TBGT 3301 (isotype).

This species is similar to Schiffnerula wedeliae and $S$. spilanthi but differs from both in having shorter conidia of the genus Questieriella.

Schiffnerula fici Sahni, Mycopath. Mycol. Appl. 23: 332, 1964.

Colonies foliicolous, amphigenous, black to ash coloured, up to $2 \mathrm{~mm}$ in diameter, coalesced, often eased off easily. Hyphae branched, septate, appressoriate, appressoria globose to ovate, entire. Sarcinella conidia borne on a short pedicels, conidia 5-6-celled, sarciniform, black, constricted at the septa, 23$34 \mu \mathrm{m}$ in diameter. Questieriella conidia directly borne from the mycelial cells, light brown, falcate, 3-septate, middle cells darker than the end cells, taper towards the apices, 35-49 $\times 9$
$11 \mu \mathrm{m}$, often pedicel is attached to one end of the spore. Perithecia globose, sessile, mucus diffluent at maturity, 83-167 $\mu \mathrm{m}$ in diameter; asci few to many, aparaphysate, subglobose to broadly ellipsoidal, sessile, 8-spored, 40-43 $\times$ 23-27 $\mu \mathrm{m}$; ascospores brown, uniseptate, constricted at the septum, 16-23 × 10-12 $\mu \mathrm{m}$, rounded at both ends, wall smooth.

On leaves of Ficus infectoria Roxb. (Moraceae), Gwarghat, Jabalpur, Madhya Pradesh, September 1962, V.P. Sahni IMI 96669 (holotype).

This is the only species of the genus Schiffnerula on the members of the family, Moraceae.

Schiffnerula flacourtiae Hosag. \& JacobThomas, sp. nov.

(Fig. 52)

Anamorph - Sarcinella manilensis (Sacc.) Kranz, Sydowia 20: 215, 1968; Rajak \& Soni, Indian J. Mycol. Plant Pathol. 11: 91, 1981; Hosag. \& Shiburaj, Zoos' Print J. 18: 1193, 2003. Stigmella malinensis Sacc., Ann. Mycol. 11: 320, 1913. Piricauda malinensis (Sacc.) Moore, Rhodora 61: 100, 1959.

Coloniae epiphyllae, densae, crustosae, ad $1 \mathrm{~mm}$ diameter, confluentes et patentiae on pagina folia. Hyphae undulatae, opposite vel irregulariter acuteque vel laxe ramosae, laxe vel arte reticulatae et formans laxe rete, cellulae 19$31 \times 2-5 \mu \mathrm{m}$. Appressoria dispersa, opposita, unicellularis, globosa, crassa posita, sessilis, integra, 4-7 × 4-10 $\mu \mathrm{m}$. Conidiophorae micronematae, mononematae, simplices, unicellularis, plerumque rectae, 4-12 × 4-6 $\mu \mathrm{m}$; cellulae conidiogenae integratae, terminalis, monoblasticae, determinatae, cylindraceae; conidia simplices, solitaris, sicca, acrogena, ovata, globosa vel subglobosa, 4-9 cellula, constrictus ad septata, nigra, sarciniformes, 21-26 × 16-22 $\mu \mathrm{m}$. Conidia Questieriella recta vel leniter curvula, 3-septata, constrictus ad septata, cellulae terminalis acutae, 28-34 × 9-12 $\mu \mathrm{m}$. Thyriothecia dispersa, orbicularis, radiates ad initio, portionio centralis dissolutus ad maturitata, ad $80 \mu \mathrm{m}$ diameter; asci pauci, globosi, octospori, ad $33 \mu \mathrm{m}$ diameter; ascosporae oblongae, conglobatae, uniseptatae, constricttus ad septatae, brunneae, 16-19 × 4-7 $\mu \mathrm{m}$, parietus glabrus. 


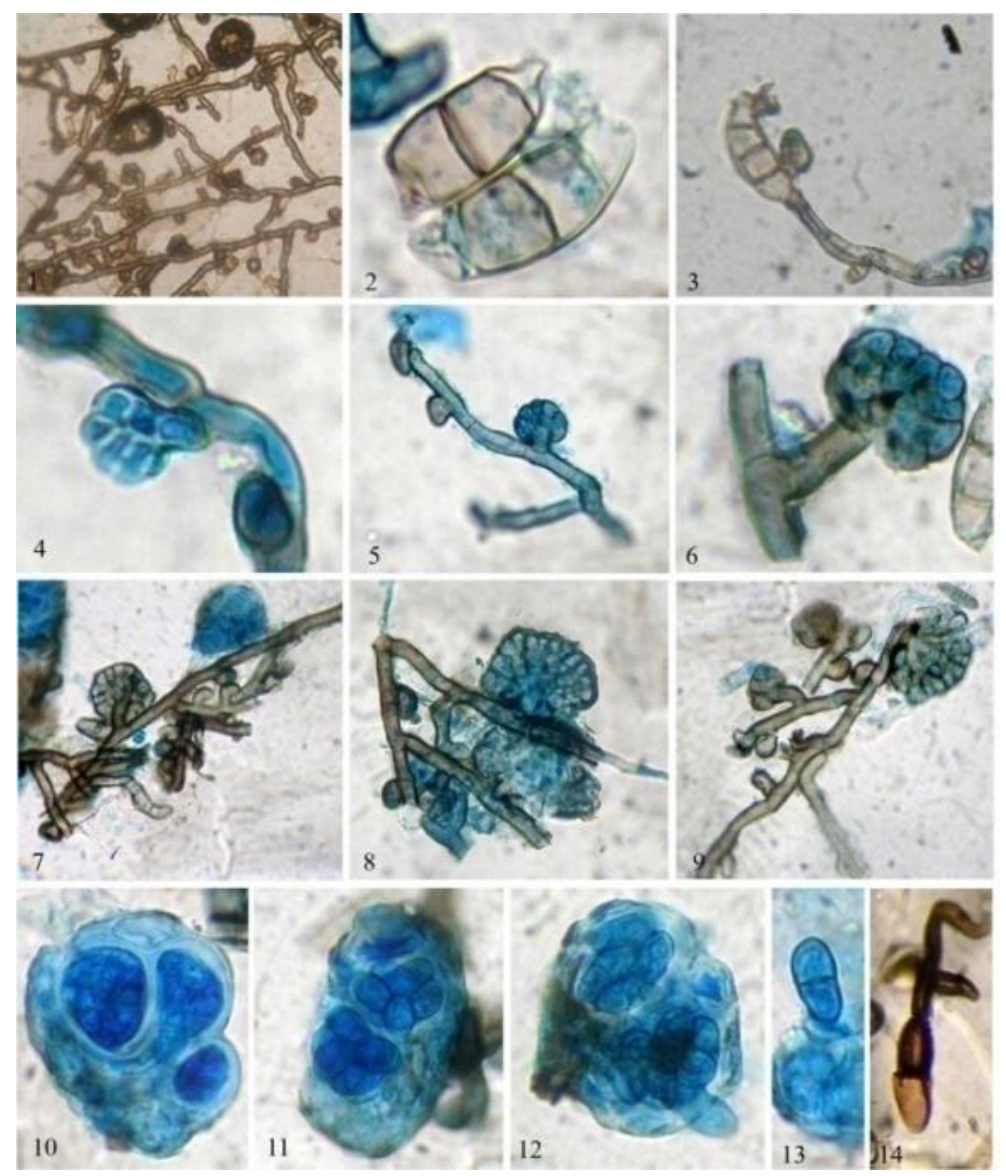

Fig. 49 - Schiffnerula ecliptae 1 Colony with thyriothecia, 2 Questieriella conidia, 3 Germinating Questieriella conidia, 4-9 Developmental stages of thyriothecia, 10-12 Thyriothecia with asci, 13 Ascospore, 14 Germinating ascospore.

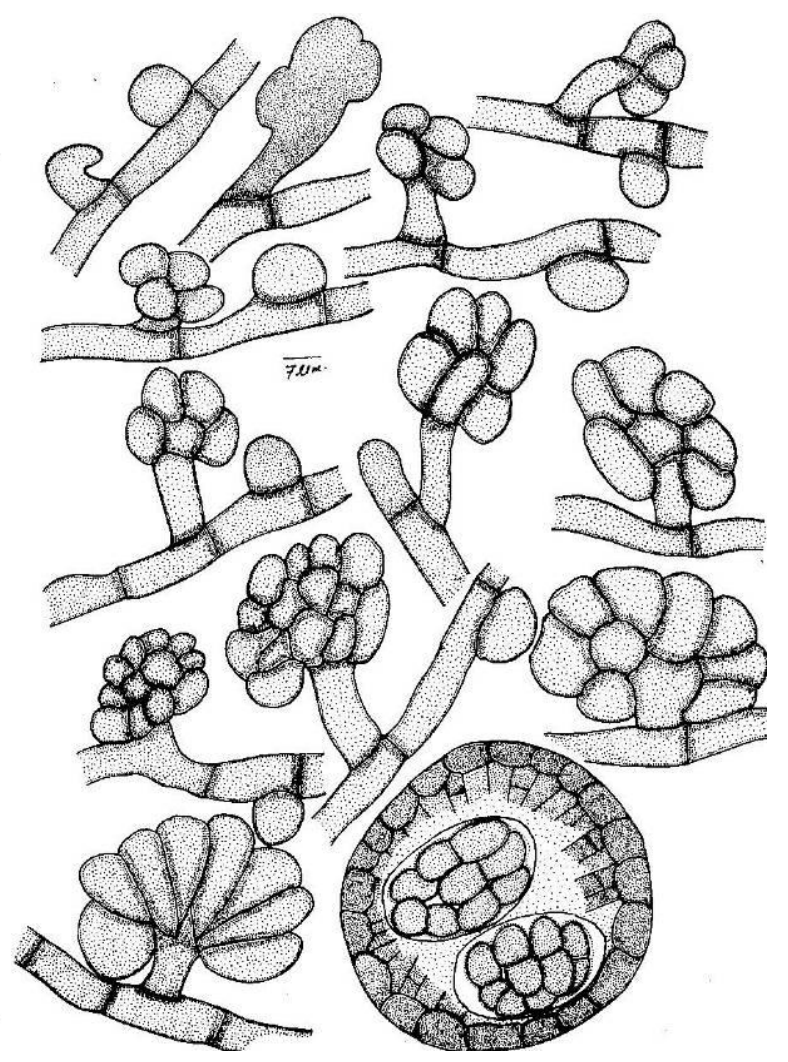

Fig. 50 - Development of ascoma in Schiffnerula ecliptae 


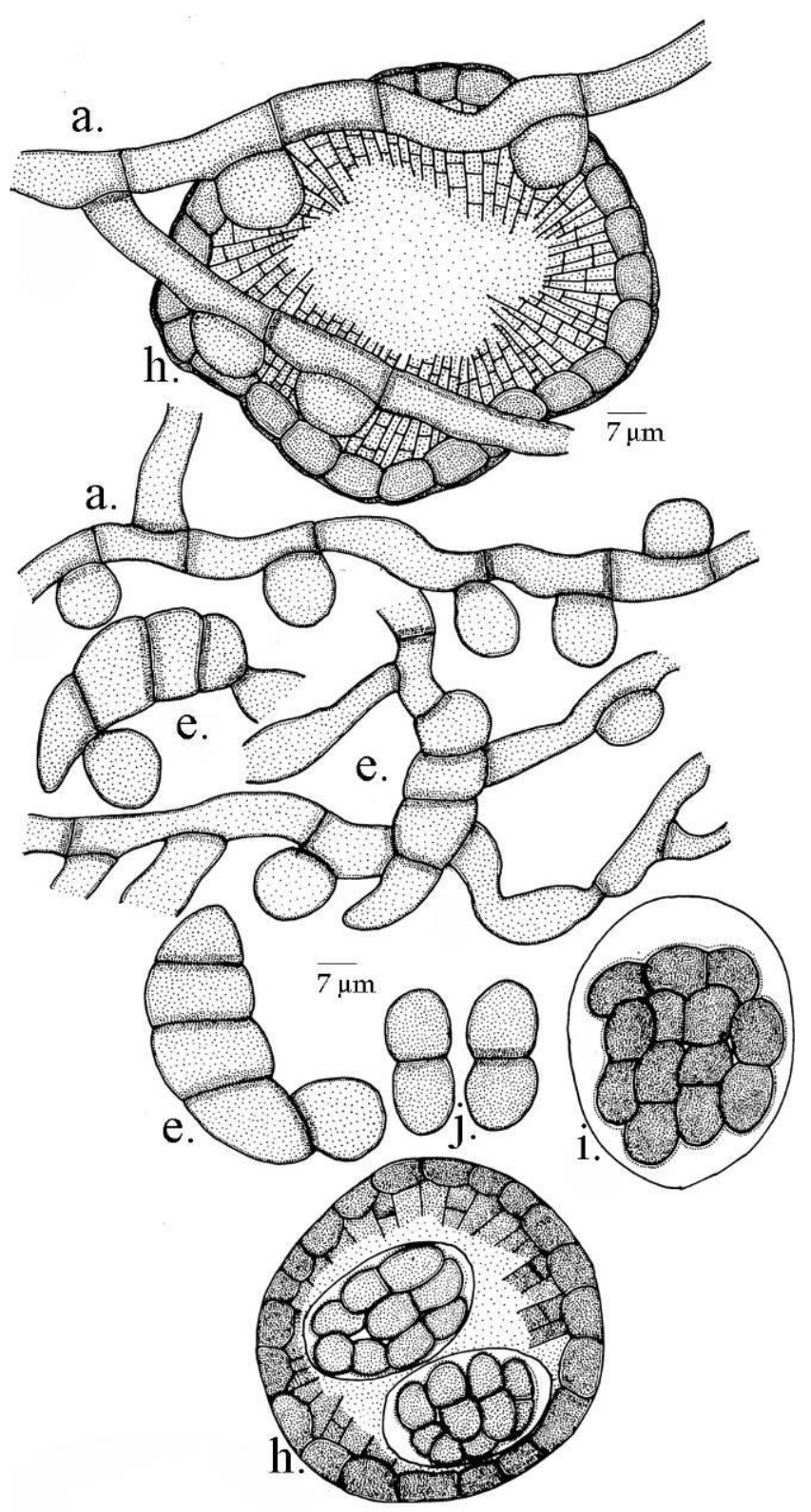

Fig. 51 - Schiffnerula ecliptae

Colonies epiphyllous, dense, crustose, up to $1 \mathrm{~mm}$ in diameter, confluent and uniformly scattered on the leaves. Hyphae undulate, branching opposite to irregular at acute to wide angles, loosely to closely reticulate to form a loose net, cells $19-31 \times 2-5 \mu \mathrm{m}$. Appressoria scattered, opposite, unicellular, globose, broad based, sessile, entire, 4-7 × 4-10 $\mu \mathrm{m}$. Conidiophores micronematous, mononematous, simple, unicellular, mostly straight, 4-12 $\times$ 4-6 $\mu \mathrm{m}$; conidiogenous cells integrated, terminal, monoblastic, determinate, cylindrical; conidia simple, solitary, dry, acrogenous, ovate, globose to subglobose, 4-9 celled, constricted at the septa, charcoal black, sarciniform, 21-26 × 16-22 $\mu \mathrm{m}$. Conidia of Questieriella present, straight to slightly curved, 3-septate, constricted at the septa, end cells acute, 28-34 × 9-12 $\mu \mathrm{m}$. Thyriothecia scattered, orbicular, initially radiating, later central portion dissolved, upto $80 \mu \mathrm{m}$ in diameter; asci few, globose, octosporous, upto $3 \mu \mathrm{m}$ in diameter; ascospores oblong, conglobate, uniseptate, constricted at the septum, brown, 16-19 × 4-7 $\mu \mathrm{m}$, wall smooth.

Material examined - India, Kerala, Thiruvananthapuram, near Peppara dam, Peppara Wildlife Sanctuary, on leaves of Flacourtia sp. (Flacourtiaceae), 31 March 2007, Jacob 


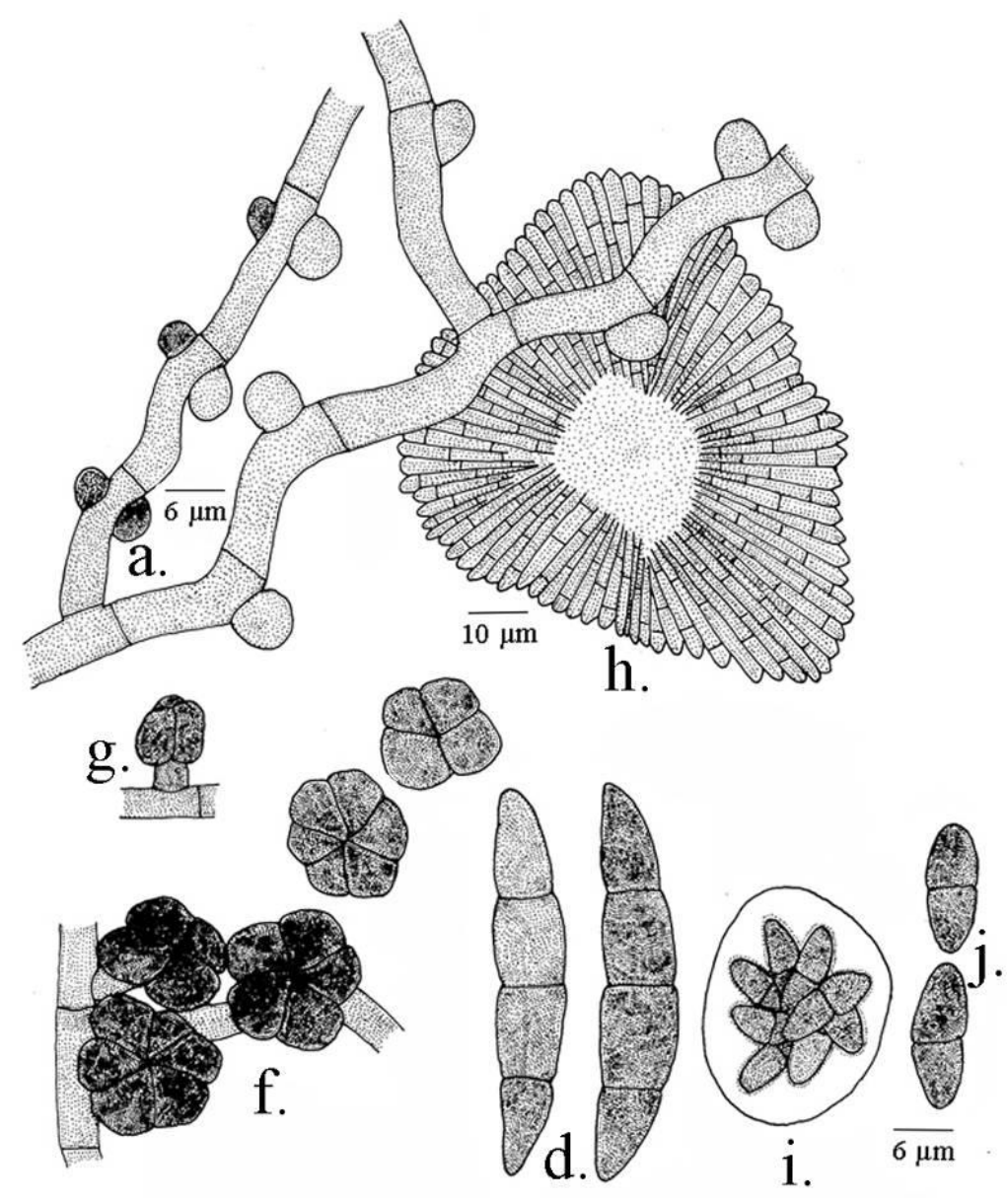

Fig. 52 - Schiffnerula flacourtiae

Thomas \& al, HCIO 49663 (holotype), TBGT 3905 (isotype). Anamorphs: India, Kerala, Idukki, Munnar Kannimala Estate, on leaves of Flacourtia sp. (Flacourtiaceae), 20 December 2001, S. Shiburaj HCIO 44408, TBGT 586; Madhya Pradesh, Jabalpur, Bargi forest, $F$. ramontchi L. (Flacourtiaceae), November 1977, K.K. Soni IMI 224095.

Schiffnerula girijae Hosag. \& Archana, J. Sci. Trans. Technov. 4: 90, 2010. (Figs 53-54)

Anamorph - Sarcinella fumosa Sahni, Mycopath. Mycol. Appl. 23: 336, 1964; Hosag., Zoos' Print Journal 18(4): 1076, 2003. Colonies hypophyllous, crustose, subdense, up to $3 \mathrm{~mm}$ in diameter, confluent. Hyphae substraight to flexuous, branching opposite, alternate to irregular at acute to wide angles, loosely to closely reticulate, cells $8-32 \times 3-5$ $\mu \mathrm{m}$. Appressoria alternate, opposite to unilateral, sessile, globose, ovate, entire, 6-11 × 6-10 $\mu \mathrm{m}$. Conidia of Questieriella scattered, pale brown, fusiform, curved, 3-septate, constricted at the septa, tapering towards both ends, 24-39 $\times$ 6-9 $\mu \mathrm{m}$. Sarcinella conidiophores micronematous, simple, branched, straight to flexuous, pale brown, $0-2$ septate, $8-20 \times 3-8 \mu \mathrm{m}$; conidiogenous cells monoblastic, integrated, mostly terminal, cylindrical; conidia solitary, dry, simple, subspherical to sarciniform, 2-8-celled, brown when young, carbonaceous black at maturity, sarcinately septate, constricted at the septa, $16-40 \mu \mathrm{m}$ in diameter, wall smooth. Thyriothecia few, orbicular, up to $90 \mu \mathrm{m}$ in diameter; asci globose, octosporous, 16-25 $\times$ 11-16 $\mu \mathrm{m}$; ascospores oblong, conglobate, brown, uniseptate, constricted at the septum, 16-24 × 8-10 $\mu \mathrm{m}$, wall smooth.

Material examined - India, Kerala, Thiruvananthapuram, Palode, Karimancode, on leaves of Aegle marmelos (L.) Corr. Serr. (Rutaceae), 8 January 2008, K. Girija TBGT 3537 (holotype), HCIO 49292 (isotype); Palode, TBGRI campus, 18 December 2000, H. Biju HCIO 46275, TBGT 1921; 17 January 2001, H. Biju HCIO 46127, TBGT 1890; 21 June 2001, M. Kamarudeen HCIO 44205, TBGT 583. 


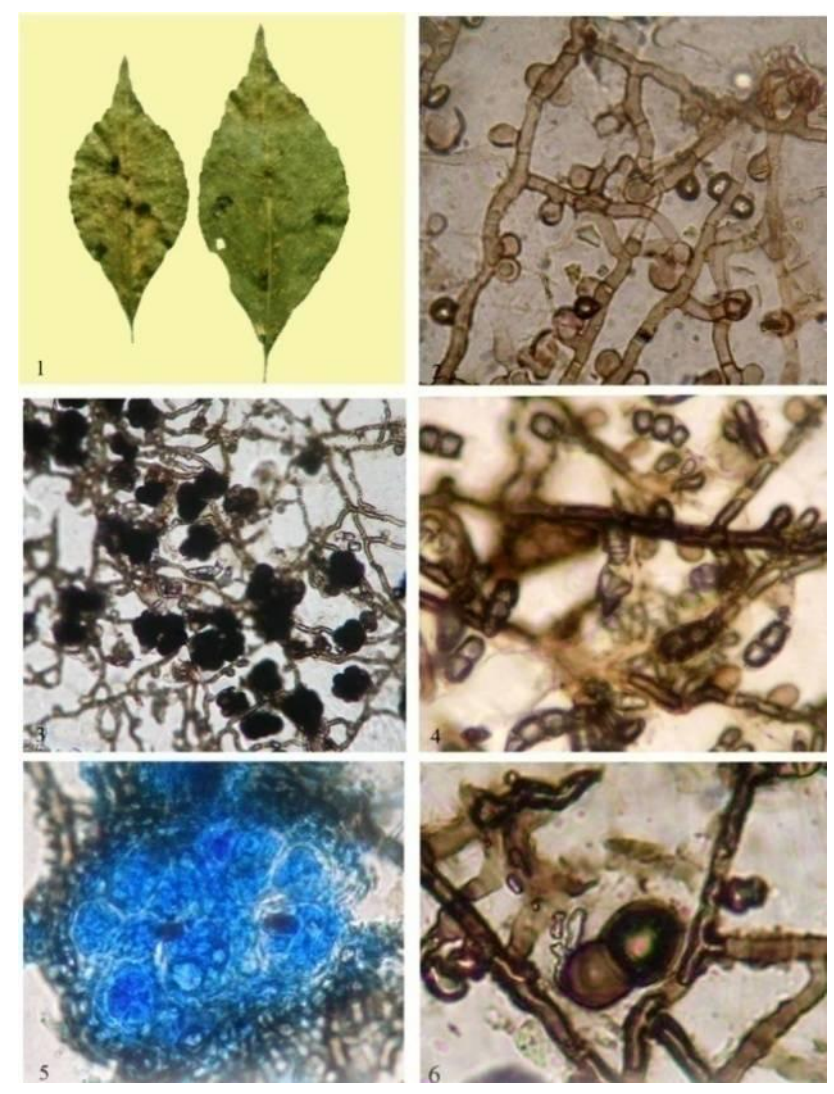

Fig. 53 - Schiffnerula girijae, 1 Infected leaves, 2 Appressoriate mycelium, 3 Sarciniform conidia, 4 Spores of Questieriella, 5 Perithecia with exposed asci, 6 Ascospore.
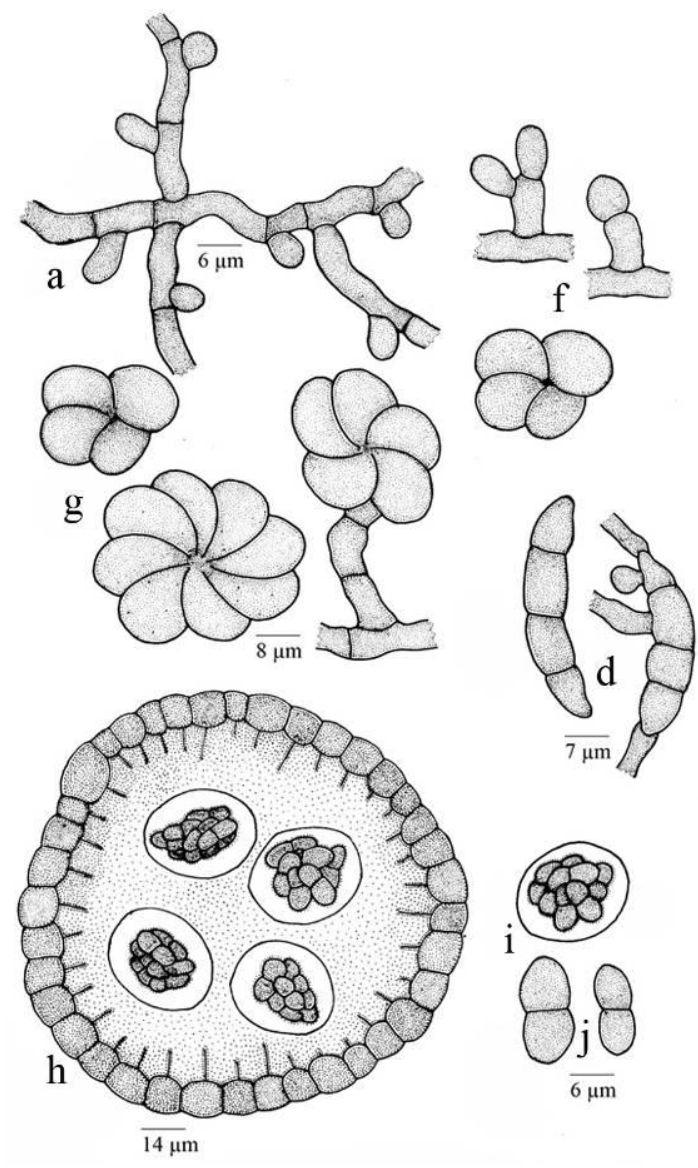

Fig. 54 - Schiffnerula girijae 
Schiffnerula glochidii Hosag., J. Mycopathol. Res. 44: 21, 2006.

(Fig. 55)

Anamorph - Sarcinella glochidii Hosag. in Hosag., H. Biju \& Appaiah, J. Mycopathol. Res. 44: 21, 2006.

Colonies epiphyllous, subdense to dense, up to $2 \mathrm{~mm}$ in diameter, rarely confluent. Hyphae substraight to flexuous, branching opposite to irregular at acute to wide angles, loosely to closely reticulate, cells $11-32 \times 3-5 \mu \mathrm{m}$. Appressoria alternate to unilateral, globose, broad based, entire, 10-12 × 7-9 $\mu \mathrm{m}$. Questieriella - conidiophores produced lateral to the hyphae, micronematous, mononematous, 0-2-septate, simple, straight, 20-26 × 5-7 $\mu \mathrm{m}$. Conidiogenous cells terminal, rarely lateral, integrated; conidia solitary, simple, dry, fusiform, pale brown to brown, 3-septate, terminal cells acute to subacute at the tip, 32-37 $\times$ 7-9 $\mu \mathrm{m}$. Sarcinella conidiophores borne lateral to the hyphae, simple, micronematous, mononematous, 3-5 $\mu \mathrm{m}$ long, in the same conidium initials have long, 0-2-septate conidiophores; conidiogenous cells integrated, monoblastic, terminal; conidia solitary, dry, acrogenous, simple, globose, sarciniform, 2-8-celled, carbonaceous black, constricted at the septa, 24$40 \mu \mathrm{m}$ in diameter, wall smooth.

Thyriothecia few, orbicular, initially radiating, later central portion dissolved, up to $72 \mu \mathrm{m}$ in diameter; asci few, globose, octosporous, up to $32 \mu \mathrm{m}$ in diameter; ascospores oblong, conglobate, brown, uniseptate, constricted at the septa, 24-26 × 18-20 $\mu \mathrm{m}$, wall smooth.

Material examined - India, Karnataka, Coorg, Madikeri, Talacauvery, Bramahgiri, MPCA, on leaves of Glochidion sp. (Euphorbiaceae), 13 November 2003, V.B. Hosagoudar \& al HCIO 45723 (holotype-Anamorph), TBGT 1472 (isotype-Anamorph); Kerala, Trissur, Vazhachal, Peringolkoothu Dam site, on leaves of Glochidion sp. (Euphorbiaceae), 23 October 2002, A. Manojkumar \& H. Biju HCIO 44670 (holotype), TBGT 951 (isotype of anamorph).

Schiffnerula ambigua Petrak, S. brideliae Hansf., S. crotonis Hansf. and S. ricini Hansf. are known on the members of the family Euphorbiaceae (Hosagoudar 2003b). But this is the only species on this host genus.
Schiffnerula hughesii Hosag., Zoos Print J. 18: 1161, 2003.

(Fig. 56)

Colonies epiphyllous, dense, up to $2 \mathrm{~mm}$ in diameter, rarely confluent. Hyphae straight to flexuous, branching irregular at acute angles, loosely to closely reticulate, cells $19-23 \times 3-5$ $\mu \mathrm{m}$. Appressoria alternate, mostly unilateral, often $1 \%$ opposite, globose, mammiform, sessile to slightly stipitate, entire, angular to slightly lobate, 6-8 $\mu \mathrm{m}$ in diameter. Thyriothecia scattered to loosely grouped, often connate, orbicular, initially radiate, later carbonaceous black, up to $100 \mu \mathrm{m}$ in diameter, margin with radiating cells, central portion dissolved and asci exposed at maturity; asci 4-5 per thyriothecia, globose, rarely slightly ovate, octosporous, $28-40 \mu \mathrm{m}$ in diameter; ascospores oblong, conglobate, brown, uniseptate, constricted at the septum, 19-23 $\times 9-11 \mu \mathrm{m}$, wall smooth.

Material examined - India, Kerala, Thiruvananthapuram, Palode, in the campus of Tropical Botanic Garden and Research Institute, on leaves of Trema orientaslis (L.) Blume (Ulmaceae), 15 January 2002, V.B. Hosagoudar HCIO 44411 (holotype), TBGT 598 (isotype).

Schiffnerula tremae Sydow and S. clemensiae Petrak are known on this host genus from Venezuela and Philippines. However, $S$. tremae and $S$. clemensiae appear to be conspecific because both the species occur hypophyllously, have very few appressoria and have very similar measurements in thyriothecia, asci and ascospores (Sydow 1930a, b, Hughes 1987). However, the present species stands very distinct from both the species in having epiphyllous and smaller colonies, entire to angular to slightly lobate and also with $1 \%$ opposite appressoria and smaller ascospores. Sivanesan (1984) has treated Schiffnerula tremae synonymous with Rhytidenglerula tremae (Sydow) Arx. Schiffnerula hughesii differs from it in having sessile perithecia in contrast to stipitate one and the ascospores lack hyaline band in each cell.

Schiffnerula lagerstroemiae Hosag. \& Riju, sp. nov.

(Figs 57-58)

Anamorph - Sarcinella lagerstroemiae Hosag. \& Mohanan, New Botanist 22: 31, 1995. 


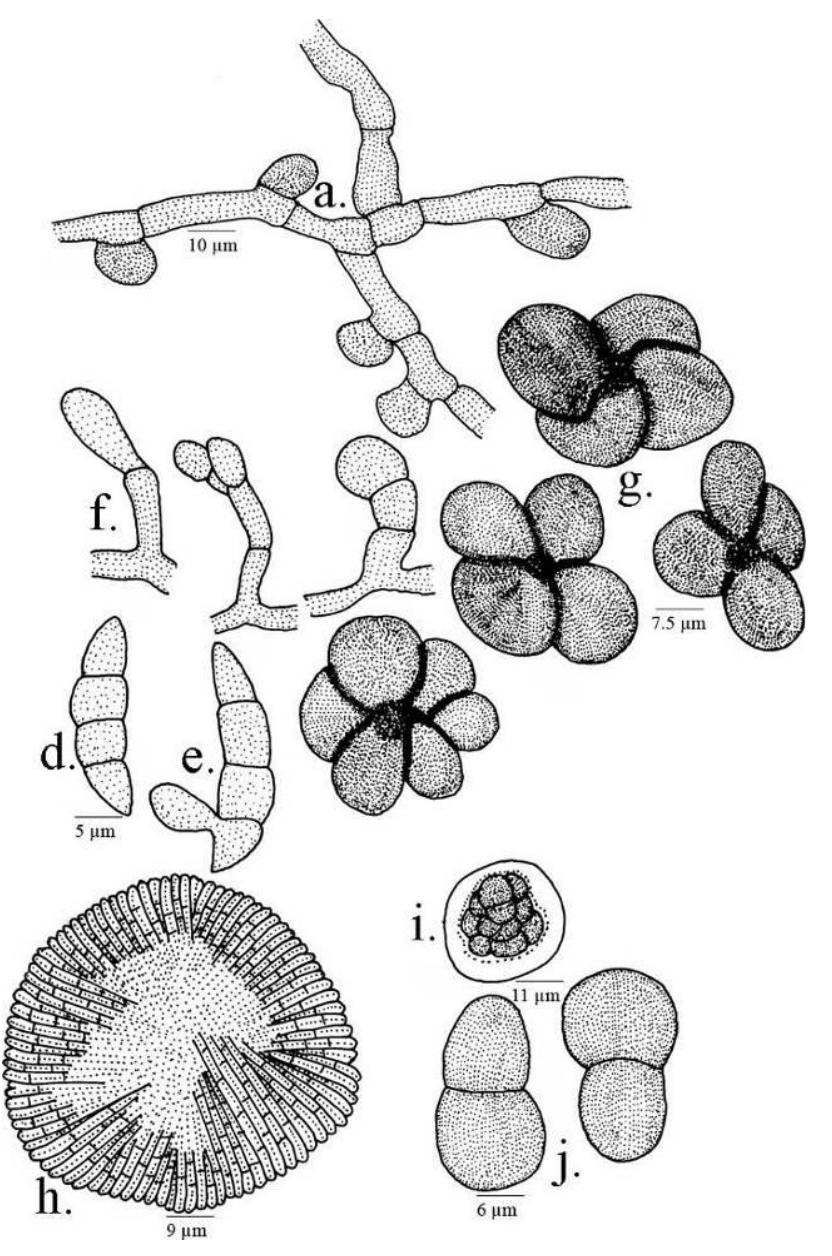

Fig. 55 - Schiffnerula glochidii
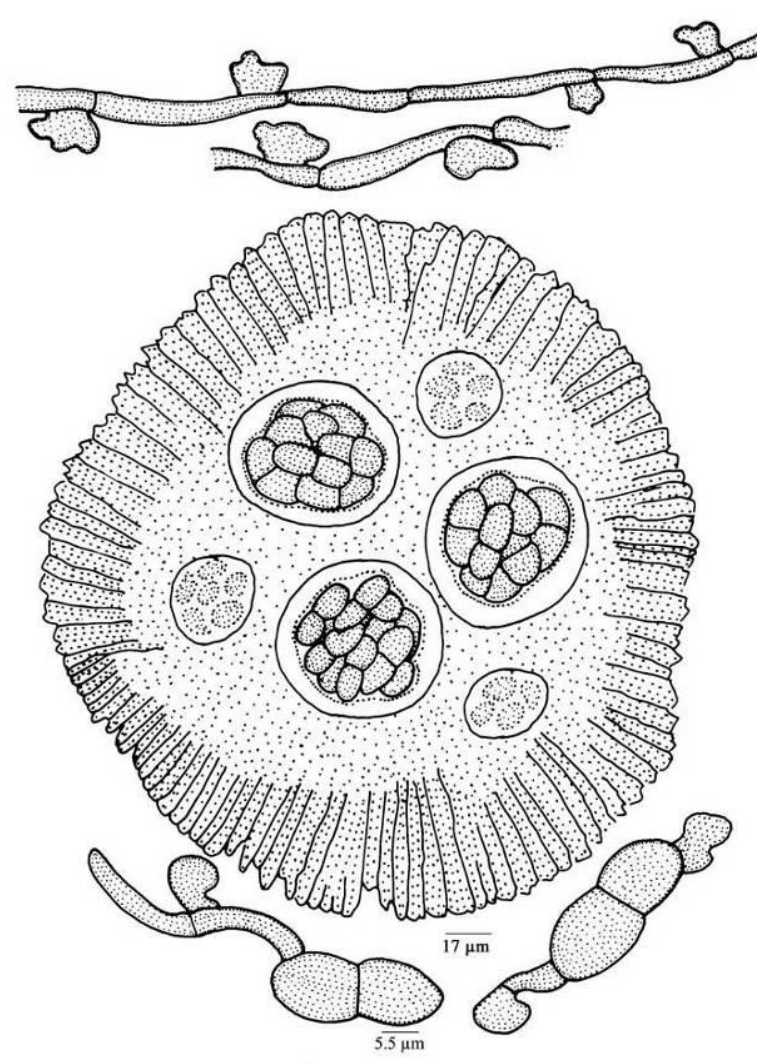

Fig. 56 - Schiffnerula hughesii 


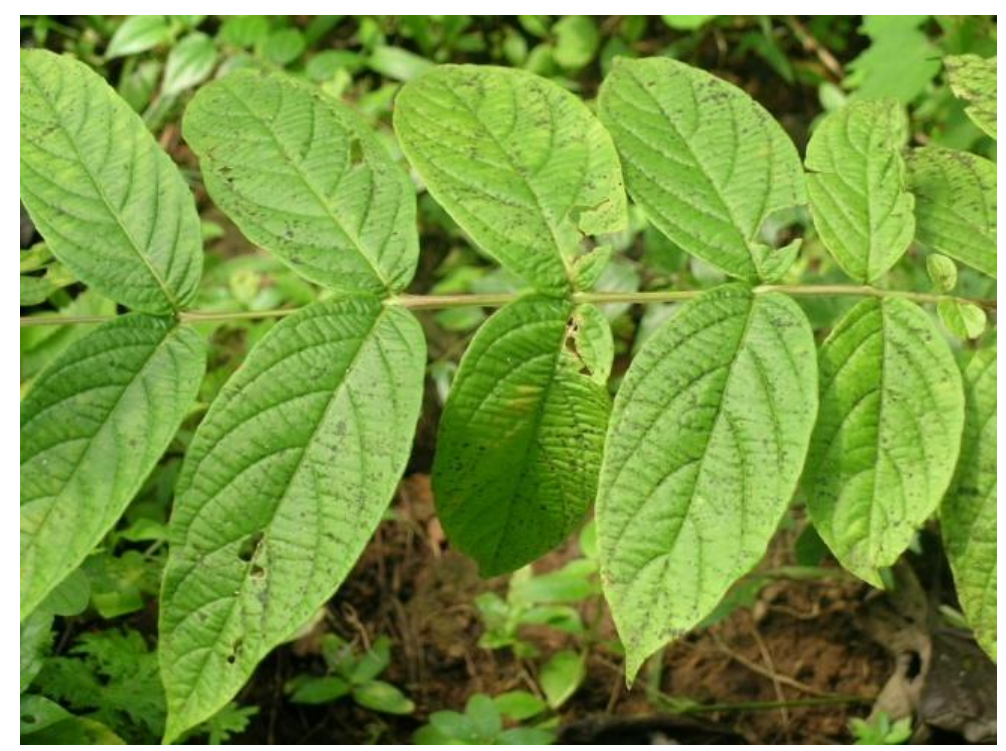

Fig. 57 - Schiffnerula lagerstroemiae, Infected leaves.

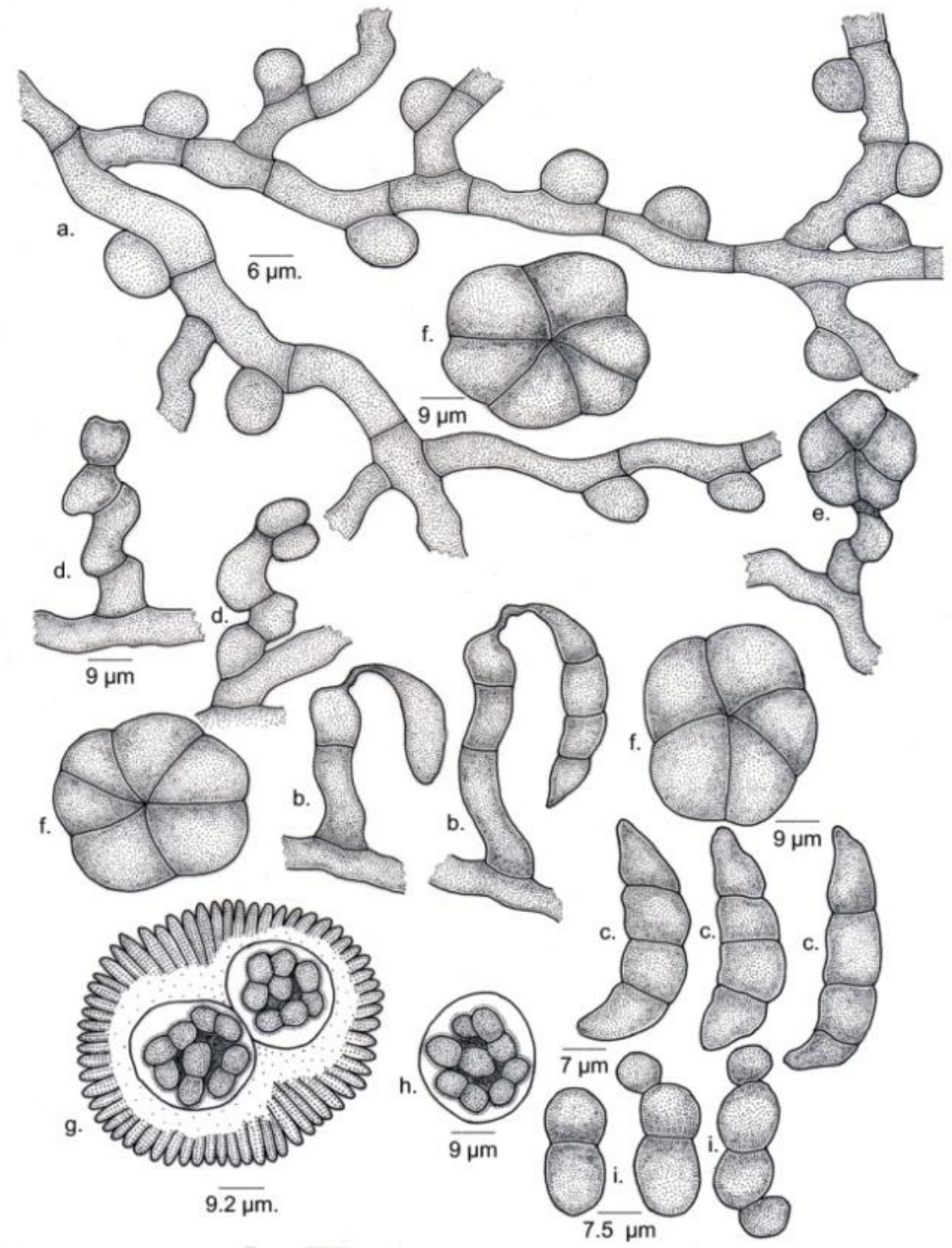

Fig. 58 - Schiffnerula lagerstroemiae 
Coloniae epiphyllae, densae, confluentes, ad 2 $\mathrm{mm}$ diameter Hyphae rectae vel undulatae, opposite vel alternatim acuteque vel laxe ramosae, laxe vel arte reticulatae, cellulae 11$26 \times 4-7 \mu \mathrm{m}$. Appressoria alternata, unilateralis, globosa, mammiformes, integra, 6-9 $\times 8-11$ $\mu \mathrm{m}$. Conidia Questieriella pauca, dispersa, producentes a hyphis cellula lateralis, curvula, 3-septata, leniter constrictus ad septata, attenuata ad ambi apicem, 28-37 × 8-11 $\mu \mathrm{m}$. Conidiophora Sarcinella producentes hyphis lateralis, solitaria, recta, flexuosa, macronemata, mononemata, 0-3-septata, 20-31 × 4-6 $\mu \mathrm{m}$; cellulae conidiogenae terminalis, monoblasticae, integratae, cylindraceae. Conidia Sarci-nella blastica, terminalis, plerumque sessilis, solitaria, sicca, ovata vel globosa, sarciniformes, 2-8cellula, constrictus ad septata, 17-40 $\mu \mathrm{m}$ in diameter, parietus glabrus. Thyriothecia dispersa, globosa, orbicularis, cellulae peridiales radiatae ad initio, tandem portionio ad centro dissolutus et asci expositi, ad 66 $\mu \mathrm{m}$ diameter, cellulae marginales radiatae; asci 12-per thyriotheciis, globosi, 4-6-spori, bitunicati, 17-26 $\mu \mathrm{m}$ diameter; ascosporae cylindraceae, oblongae, uniseptatae, constrictus ad septatae, 17-22 × 6-9 $\mu \mathrm{m}$, hyalinae ad initio et brunneae ad maturitatae.

Colonies epiphyllous, dense, confluent, up to $2 \mathrm{~mm}$ in diameter. Hyphae substraight to undulating, branching opposite to alternate at acute to wide angles, loosely to closely reticulate, cells 11-26 × 4-7 $\mu \mathrm{m}$. Appressoria alternate, unilateral, globose, mammiform, entire, 6$9 \times 8-11 \mu \mathrm{m}$. Conidia of Questieriella type were few, scattered, attached directly to the hyphae, curved, 3-septate, slightly constricted at the septa, taper towards both ends, 28-37 $\times$ 8-11 $\mu \mathrm{m}$. Sarcinella conidiophores produced lateral to the hyphae, single, straight, flexuous, macronematous, mononematous, 0-3 septate, 20-31 $\times 4-6 \mu \mathrm{m}$; conidiogenous cells terminal, monoblastic, integrated, cylindrical. Sarcinella conidia blastic, terminal, mostly sessile, solitary, dry, ovate to globose, sarciniform, 2-8 celled, constricted at the septa, $17-40 \mu \mathrm{m}$ in diameter, wall smooth. Thyriothecia scattered, globose, orbicular, peridial cells initially radiating, later central portion dissolved by exposing the asci, up to $66 \mu \mathrm{m}$ in diameter, marginal cells radiating; asci 1-2 per thyriothecia, globose, 4-6 spored bitunicate, $17-26 \mu \mathrm{m}$ in diameter; asco-spores cylindrical, oblong, uniseptate, con-stricted at the septum, 17-22 × 6-9 $\mu \mathrm{m}$, remain hyaline for some time but turn brown at maturity.

Material examined - India, Kerala, Wayanad, $16^{\text {th }}$ mile, Padinharathara, on leaves of Lagerstroemia microcarpa Wight (Lythraceae), 10 November 2007, M.C. Riju HCIO (holotype), TBGT 2967 (isotype). Hosagoudar \& Mohanan (1995) described Sarcinella lagerstroemiae on Lagerstroemia parviflora from Andhra Pradesh. Subsequently, it was collected from Coorg, Karnataka (Hosagoudar et al. 2006).

Schiffnerula meliosmatis Hosag., JacobThomas \& Agarwal, J. Yeast \& Fungal Res. 2: 86, 2011.

Colonies epiphyllous, thin, up to $2 \mathrm{~mm}$ in diameter, confluent. Hyphae brown, substraight to flexuous, branching alternate to irregular at acute to wide angles, loosely to closely reticulate, cells $16-26 \times 4-5 \mu \mathrm{m}$. Appressoria alternate to unilateral, unicellular, globose, ovate, entire, 7-10 × 7-11 $\mu \mathrm{m}$. Conidiophores macronematous, mononematous, simple, straight, light brown, smooth, 7-10 × 7-8 $\mu \mathrm{m}$; conidiogenous cells integrated, mostly terminal, monoblastic, determinate, cylindrical; conidia simple, solitary, dry, acrogenous, globose to subglobose, smooth, carbonaceous black, constricted at the septa, 5-8 celled, sarciniform, 24-34 × 21-29 $\mu \mathrm{m}$. Conidia of Questieriella were scattered or attached to hyphae, slightly curved, 3septate, slightly constricted at the septa, germinating, light brown, 36-41 × 7-12 $\mu \mathrm{m}$, wall smooth. Thyriothecia scattered, orbicular, initially radiating, dehiscing by disintegrating the cells at the centre forming a pore and exposing the asci, upto $62 \mu \mathrm{m}$ in diameter, marginal cells radiating; asci $1-4$ per thyriothecia, ovate to subglobose, octosporous, 30-40 $\mu \mathrm{m}$ in diameter; ascospores oblong, conglobate, uniseptate, strictly constricted at the septum, brown, 15-25 × 7-12 $\mu \mathrm{m}$.

Material examined - India, Kerala, Thiruvananthapuram, Peppara Wild Sanctuary, Near Peppara Dam, 1 March 2008, on leaves of Meliosma simplicifolia ssp. pungens (Wallich 


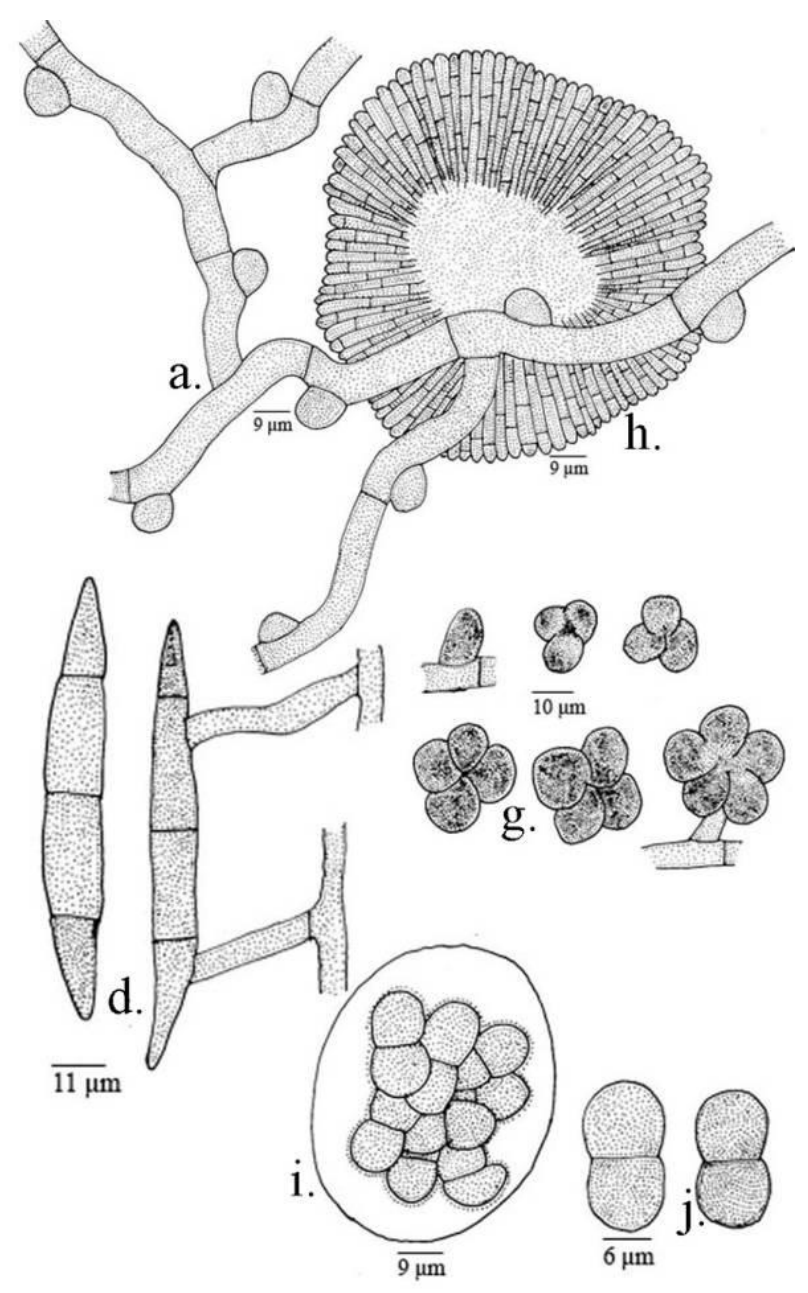

Fig. 59 - Schiffnerula meliosmatis

ex Wight \& Arn.) Beus. (Sabiaceae), Jacob Thomas \& al. HCIO 48418 (holotype), TBGT 3139 (isotype).

This is the first species of the genus Schiffnerula on members of the family Sabiaceae.

Schiffnerula mirabilis Hohn., Sitz. K. Akad. Wiss. Wien., math.-nat. kl. I Abt. 118: 867, 1909; Hosag. \& Sabeena, Taiwania 55(3): 252, 2010. Schiffnerula pitteriana Sydow, Ann. Mycol. 28: 161, 1930. Schiffnerula malabarensis Ramakr. \& Sund., Proc. Indian Acad. Sci. 38: 188, 1953.

(Fig. 60)

Colonies amphigenous, subdense, up to $2 \mathrm{~mm}$ in diameter, confluent. Hyphae substraight to flexuous, branching opposite to unilateral at acute to wide angles, loosely reticulate, cells 20-35 × 5-7 $\mu \mathrm{m}$. Appressoria alternate to unilateral, unicellular, globose, ovate, broad based, entire, 7-12 × 10-15 $\mu \mathrm{m}$. Conidia of Questieriella were numerous, scattered, germinating to form colony, curved, 3- septate, slightly constricted at the septa, taper towards both ends, $32-55 \times 10-15 \mu \mathrm{m}$. Thyriothecia scattered, globose, orbicular, peridial cells initially radiating, later central portion dissolved by exposing asci, up to $53 \mu \mathrm{m}$ in diameter; asci 1-2 per thyriothecia, globose, ovate, octosporous, $17-30 \mu \mathrm{m}$ in diameter; ascospores conglobate, uniseptate, constricted at the septum, 17-25 $\times 7-12 \mu \mathrm{m}$.

Material examined - India, Karnataka, Coorg, Madikeri, Nishane motta, on leaves of Passiflora foetida, 11 November 2003, V.B. Hosagoudar \& al. HCIO 45731, 14 November 2003, V.B. Hosagoudar \& al. HCIO 45620, TBGT 1363; Passiflora edulis Sims (Passifloraceae), Kerala, Thiruvananthapuram, Kallara, 28 November 2008, A. Sabeena HCIO 49118, TBGT 3373.

Ramakrishnan \& Sundaram (1953) reported this on Passiflora edulis from Wayanad Kerala. After a lapse of half a century, this fungus is relocated from the lower altitudes in the southern part of Kerala State. 
Plant Pathology \& Quarantine

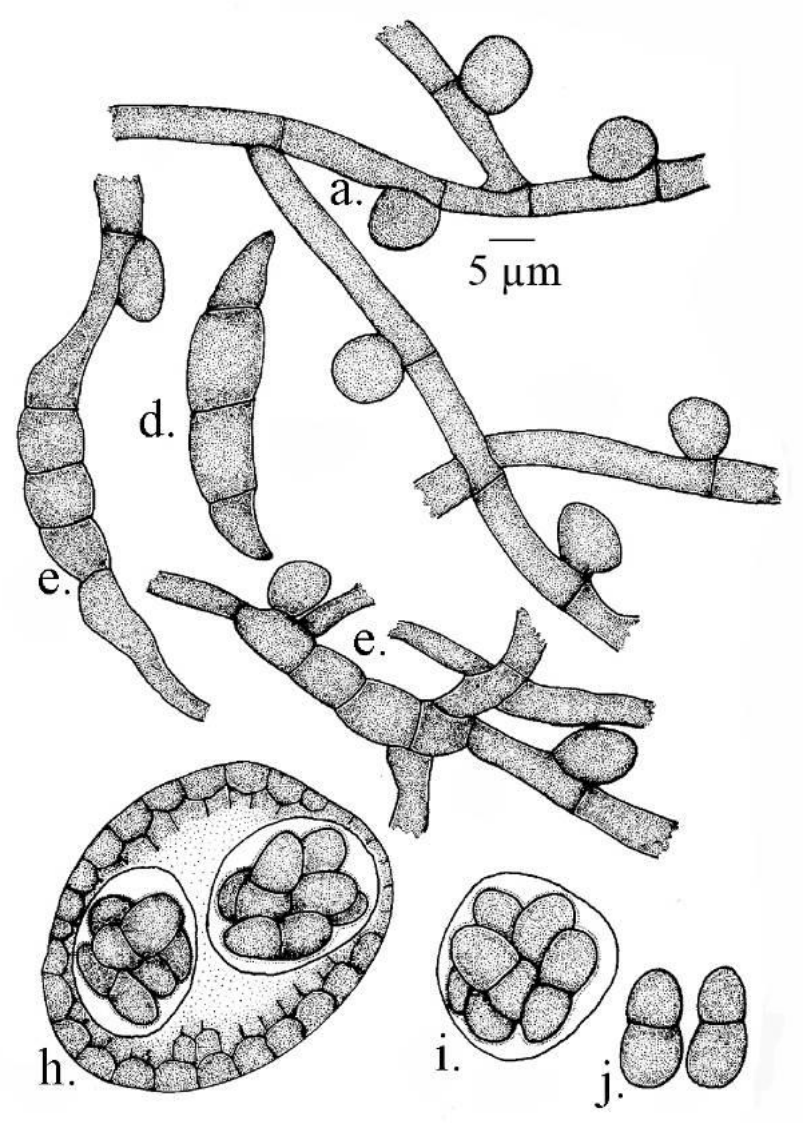

Fig. 60 - Schiffnerula mirabilis

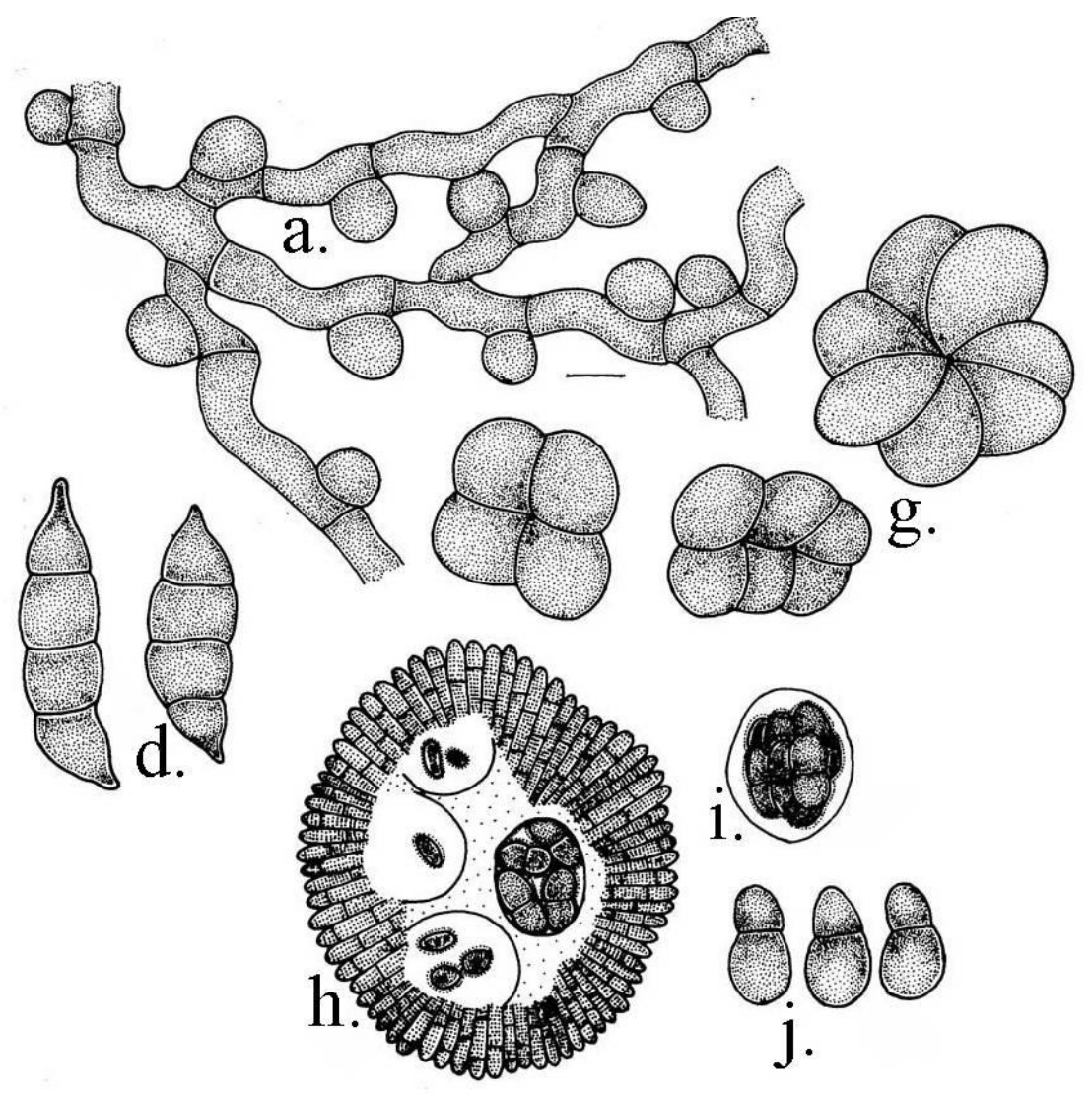

Fig. 61 - Schiffnerula palodensis 

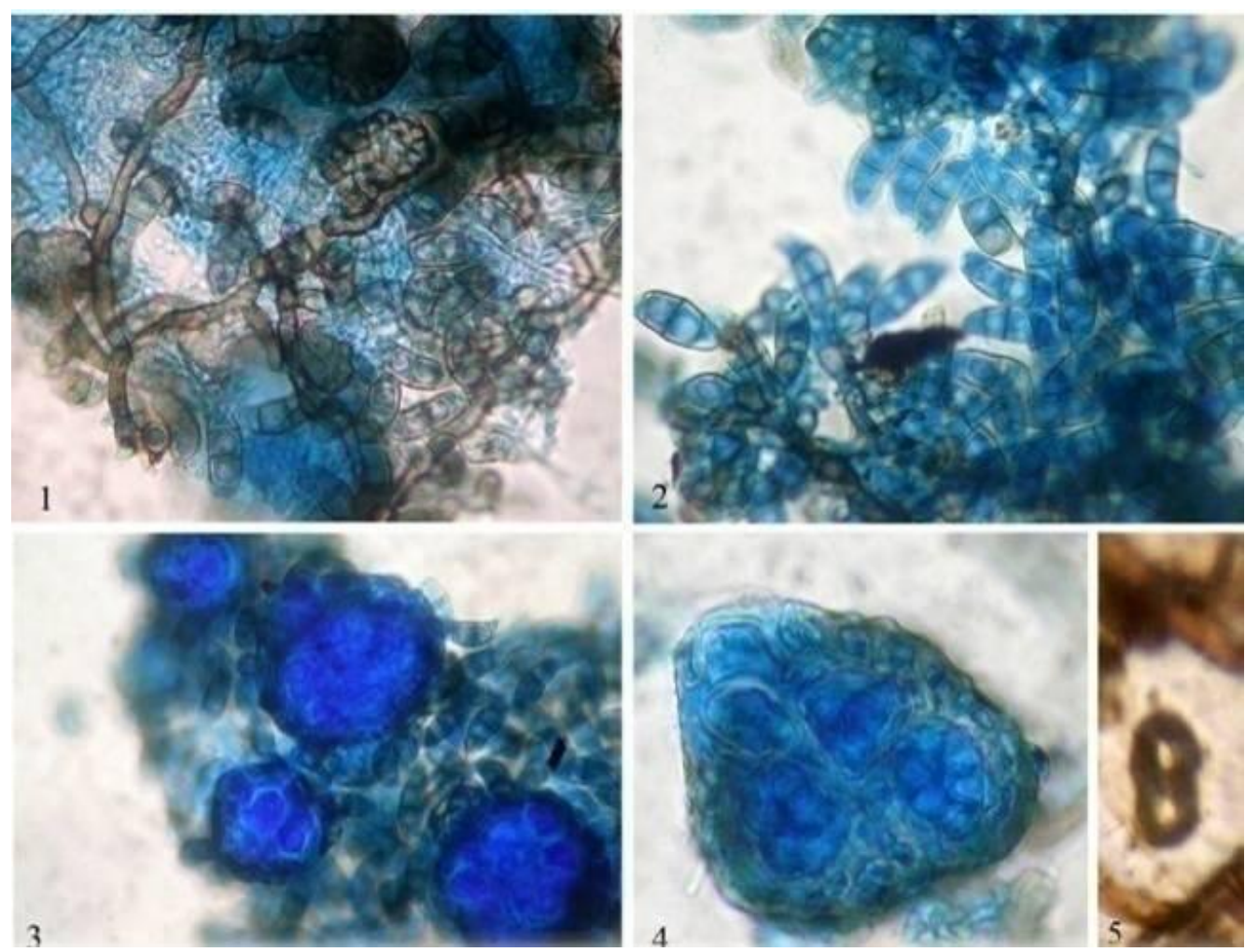

Fig. 62 - Schiffnerula palodensis, 1 Colony with thyriothecia and Questieriella conidia, 2 Questieriella conidia, 3 Thyriothecia, 4 Arrangement of asci in the thyriothecium, 5 Ascospore.

Schiffnerula palodensis Hosag. \& Riju, Bioscience Discovery 2(2): 272, 2011.

(Figs 61-62)

Colonies epiphyllous, thin, up to $2 \mathrm{~mm}$ in diameter, confluent. Hyphae substraight, branching alternate to irregular at acute to wide angles, loosely reticulate, cells 8-20 × 4-6 $\mu \mathrm{m}$. Appressoria alternate to unilateral, ovate, globose to mammiform, entire, $8-10 \times 6-10 \mu \mathrm{m}$. Conidia of Questieriella were scattered, not attached, curved, 3-septate, slightly constricted at the septa, taper towards both ends, 14-31 $\times$ 8-11 $\mu \mathrm{m}$. Sarcinella conidiophores produced lateral to the hyphae, single, straight to flexuous, micronematous, mononematous, $0-1$ septate, 5-22 x 3-5 $\mu \mathrm{m}$; conidiogenous cells terminal, monoblastic, integrated, cylindrical. Sarcinella conidia blastic, terminal, mostly sessile, solitary, dry, ovate to globose, sarciniform, cruciately septate, 3-7 celled, constricted at the septa, 19-33 $\mu \mathrm{m}$ in diameter, wall smooth. Thyriothecia scattered, orbicular, ovate, peridial cells initially radiating, later central portion dissolved by exposing the asci, up to $75 \mu \mathrm{m}$ in diameter, marginal cells radiating; asci $2-5$ per thyriothecia, globose, octosporous, bitunicate, 12-24 $\mu \mathrm{m}$ in diameter; ascospores oblong, conglobate, uniseptate, constricted at the septum, 20-23 $\times$ 10-12 $\mu \mathrm{m}$, brown at maturity, wall smooth.

Material examined - India, Kerala, Thiruvananthapuram, Palode, Chippanchira, on leaves of Solanum sp., 15 December 2008, M.C. Riju and K. Anil Kumar TBGT 3357 (holotype). Part of the collection is in HCIO, New Delhi.

Schiffnerula pulchra (Sacc.) Petrak, Ann. Mycol. 26: 397, 1928; Hughes, Can. J. Bot. 61: 1738, 1983; Hosag., H. Biju \& Appaiah, J. Mycopathol. Res. 44: 23, 2006. Apiosporium pulchrum Sacc., Thumen, Mycotheca Universalis No. 52, 1875. Dimerosporium pulchrum Sacc., Nuovo G. Bot. Ital. 7: 299, 1875. Dimerina pulchra (Sacc.) Theiss., Bot. Centralbl. Beih. 29: 64, 1912. Questiera pulchra (Sacc.) Arnaud, Les Asterinees, p. 187, 1918.

(Fig. 63)

Anamorph - Sarcinella heterospora Sacc., Fungi Italici no. 126, 1877.

Colonies epiphyllous, dense, velvety, up to $2 \mathrm{~mm}$ in diameter, rarely confluent. Hyphae straight to flexuous, branching irregular at acute angles, loosely reticulate, cells $12-16 \times$ 

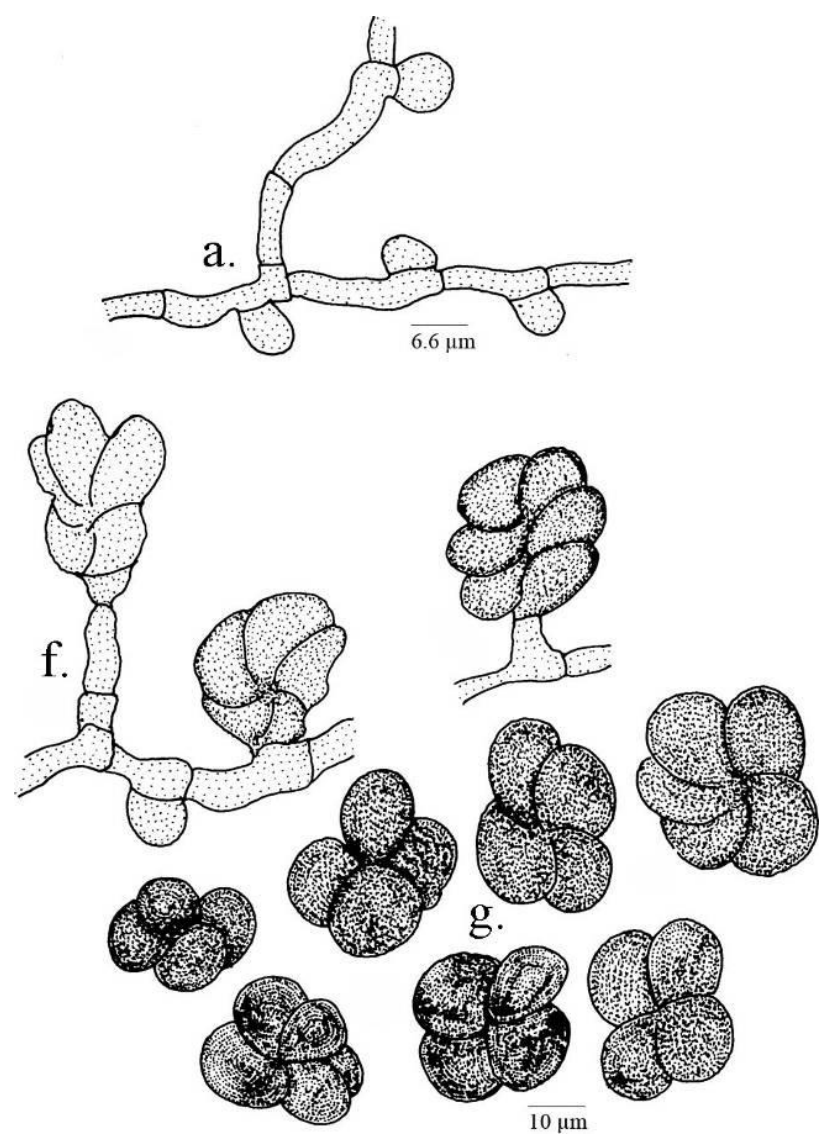

Fig. 63 - Sarcinella state of Schiffnerula pulchra

4-6 $\mu \mathrm{m}$. Appressoria alternate to unilateral, globose, broad based, entire, 8-11 × 6-8 $\mu \mathrm{m}$. Conidiophores micronematatous, mononematous, simple, straight to slightly flexuous, aseptate to 1-2-septate, $12-22 \times 4-6 \mu \mathrm{m}$; conidiogenous cells monoblastic, integrated, determinate, cylindrical. Conidia solitary, dry, acrogenous, simple, oval, spherical, charcoal black, sarciniform, 2-5-septate, constricted at the septa, 19-32 $\mu \mathrm{m}$ in diameter, wall smooth.

Material examined - India, Karnataka, Kodagu, Madikeri, Nishanemotta, on leaves of Ligustrum sp. (Oleaceae), 11 November 2003, V.B. Hosagoudar HCIO 45794, TBGT 1543.

This is the only species known on this host genus from Europe and America and is known here only with its anamorph.

Schiffnerula ricini Hansf., Proc. Linn. Soc. London 160: 117, 1947-48; Hosag., H. Biju \& Appaiah, J. Mycopathol. Res. 4: 23, 2006; Hosag. \& Riju, Indian J. Sci. \& Techn. 2(6): 7, 2009.

(Fig. 64)

Colonies amphigenous, up to $3 \mathrm{~mm}$ in diameter, epiphyllous colonies subdense, confluent, hypophyllous colonies crustose, some times confluent. Hyphae substraight to flexuous, branching opposite, irregular at acute to wide angles, loosely reticulate, cells $8-33 \times 2-5$ $\mu \mathrm{m}$. Appressoria alternate, unilateral, globose, mammiform, entire, 6-9 x 6-10 $\mu \mathrm{m}$. Conidia of Questieriella were scattered, mostly not attached, curved, 3-septate, slightly constricted at the septa, taper towards both ends, 26-31 $\times$ 8-11 $\mu \mathrm{m}$. Sarcinella conidiophores produced lateral to the hyphae, single, straight to flexuous, macronematous, mononematous, $0-2$ septate, $9-12 \times 2-5 \mu \mathrm{m}$, conidiogenous cells terminal, monoblastic, integrated, cylindrical; conidia present mostly on the lower surface of the leaves, blastic, terminal, solitary, dry, ovate to globose, sarciniform, cruciately septate, 4-8 celled, constricted at the septa, $19-31 \mu \mathrm{m}$ in diameter, brown and turn to dark at maturity, wall smooth. Thyriothecia mostly on the upper surface of the leaves, scattered, globose, orbicular to ovate, peridial cells initially radiating, later central portion dissolved by exposing asci, up to $110 \mu \mathrm{m}$ in diameter, marginal cells mostly persist and radiate; asci 4-8 per 


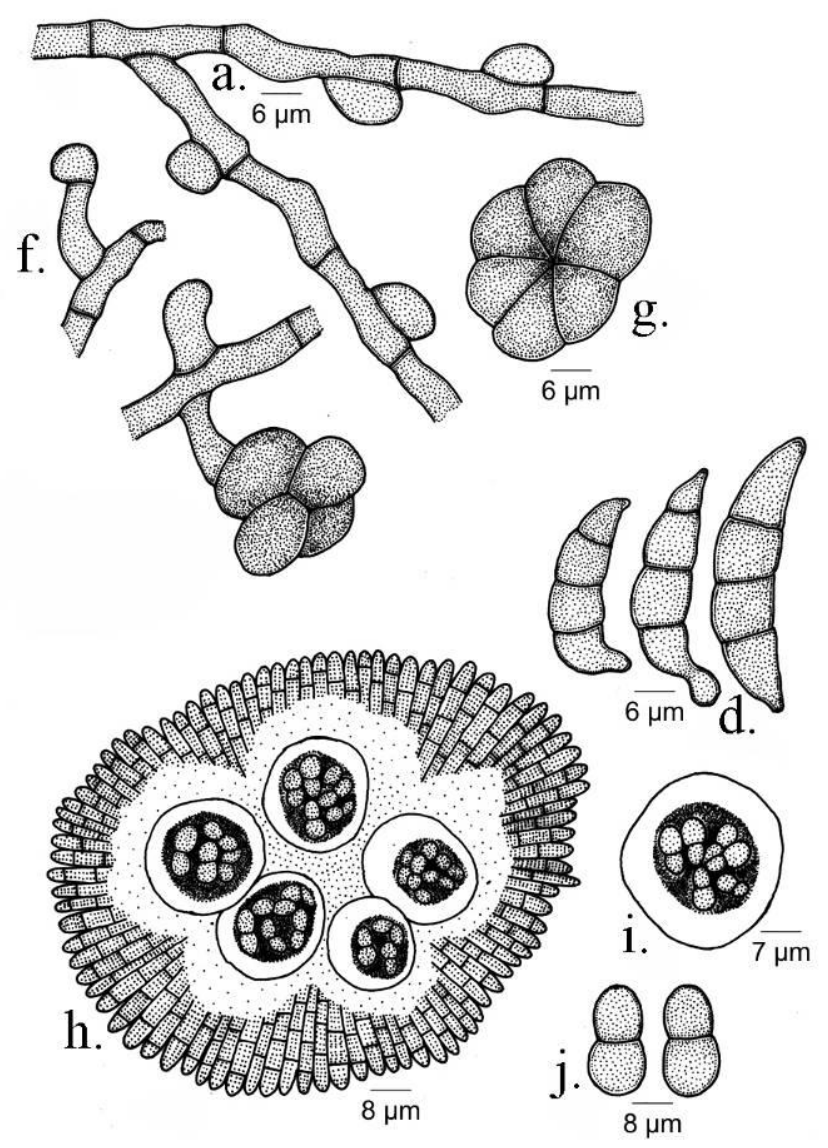

Fig. 64 - Schiffnerula ricini

thyriothecia, globose, octosporous, bitunicate, 22-29 $\mu \mathrm{m}$ in diameter; ascospores oblong, conglobate, uniseptate, constricted at the septum, 19-22 $\times 8-11 \mu \mathrm{m}$, remain hyaline for some time but turn brown at maturity.

Material examined - India, Karnataka, Kodagu, Madikeri, Nishane motta, on leaves of Ricinus communis L. (Euphorbiaceae), 14 November 2003, V.B. Hosagoudar HCIO 45663, TBGT 1410; Hoddur, 27 October 2009, Jagat Thimmaiah TBGT 5435; Kerala, Wayanad, Padinharathara, Puthusserikkadavu, 10 November 2007, M. C. Riju HCIO 48180, TBGT 2916; Thrissur, Vazhachal, Poringalkuthu, 21 August 2007, Jacob Thomas \& al HCIO 48194, TBGT 2930.

This species was reported on the same host from Uganda (Hansford 1949). Later, Sarcinella state of this fungus was reported from Coorg, Karnataka (Hosagoudar et al. 2006). However, the subsequent collection revealed both the anamorphs and teleomorph.

This reveals the affinity of the fungal flora of Uganda, Coorg and Wayanad and appears to occur only in highly elevated places.
This is the only species of the genus Schiffnerula known on the host genus Ricinus (Hansford 1949).

Schiffnerula spilanthi Hosag., Sabeena \& Riju, Indian Phytopath. 63: 321, 2010.

(Figs 65-66)

Colonies epiphyllous, thin, scattered to confluent, up to $3 \mathrm{~mm}$ in diameter. Hyphae substraight to flexuous, branching opposite, alternate to unilateral at acute to wide angles, loosely to closely reticulate, cells $10-38 \times 5-8$ $\mu \mathrm{m}$. Appressoria scattered, alternate, unilateral, rarely opposite, globose, ovate, unicellular, entire, $10-15 \times 10-14 \mu \mathrm{m}$. Conidia of Questieriella were scattered, not attached, curved, 3-septate, slightly constricted at the septa, taper towards both ends, 37-43 × 10-15 $\mu \mathrm{m}$. Sarcinella state not found. Thyriothecia scattered, ovate, orbicular, peridial cells initially radiating, later the central portion dissolved by exposing asci, 25-63 $\mu \mathrm{m}$ in diameter, marginal cells radiating; asci $2-4$ per thyriothecia, globose, octosporous, $25-35 \mu \mathrm{m}$ in diameter; ascospores oblong, conglobate, 


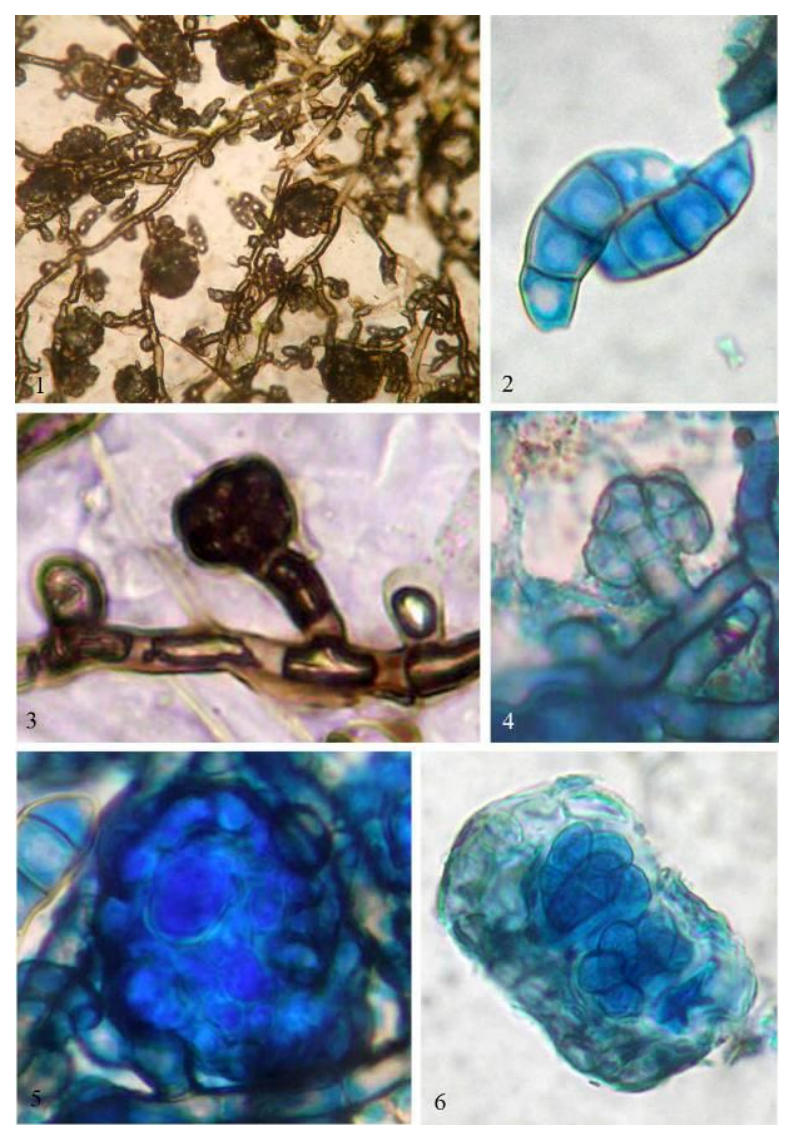

Fig. 65 - Schiffnerula spilanthi, 1 Appressoriate mycelium, 2 Conidia of Questieriella, 3-4 Thyriothecium initial and its development, 5 Dissolved upper membrance of the thyriothecium with the exposed asci, 6 Ascospores in the asci.

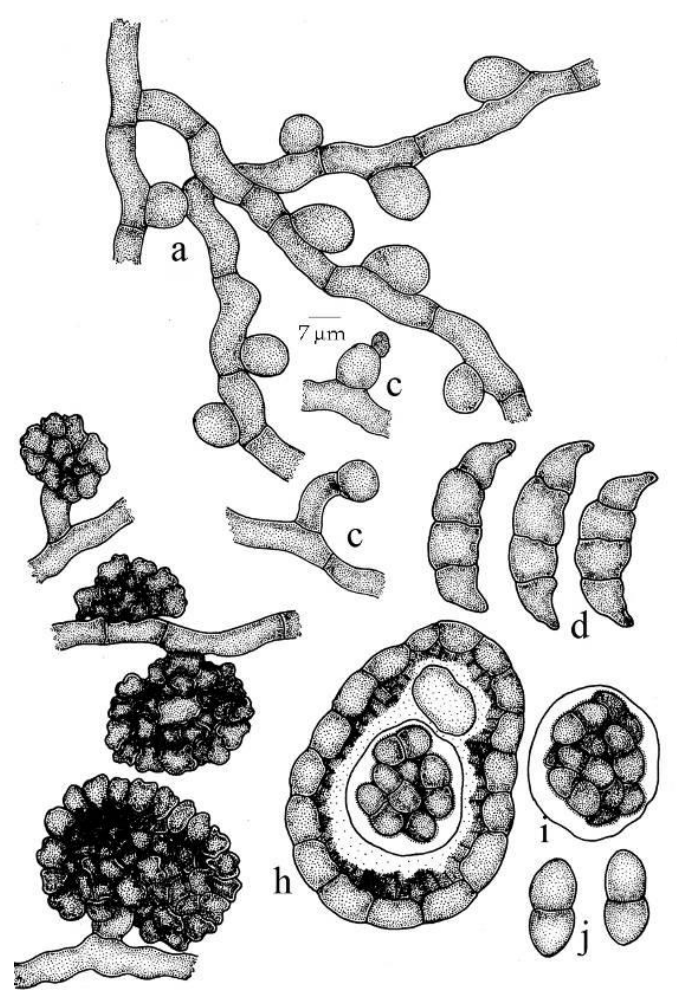

Fig. 66 - Schiffnerula spilanthi 
uniseptate, constricted at the septum, 20-23 $\times$ 10-13 $\mu \mathrm{m}$, wall smooth.

Material examined - India, Kerala, Wayanad, Padinharathara, on leaves of Spilanthes radicans Jaca. (Asteraceae), 23 December 2008 M.C. Riju HCIO 49106 (holotype), TBGT 3361 (isotype).

This species is similar to Schiffnerula wedeliae. Based on host specificity, it has been placed under a distinct species.

Schiffnerula tectonae (Thite \& Patil) Hosag., Zoos Print J. 18: 1077, 2003. Clypeolella tectonae Thite \& Patil, Geophytology 15: 84, 1985. Sarcinella tectonae Hosag. \& Manoj., Zoos' Print J. 19: 1389, 2004.

(Fig. 67)

Colonies amphigenous, mostly epiphyllous, dense, up to $1 \mathrm{~mm}$ in diameter, rarely confluent. Hyphae pale brown, slightly flexuous, branching alternate to irregular at acute angles, loosely to closely reticulate, cells $12-20$ $\times 4-7 \mu \mathrm{m}$. Appressoria brown, scattered, alternate, globose to slightly ovate, entire, $9-12 \mu \mathrm{m}$ in diameter; conidiophores simple, micronematous, mononematous, pale, entire, 5-8 $\mu \mathrm{m}$ long; Conidiogenous cells integrated, monoblastic, terminal; conidia solitary, dry, acrogenous, simple, globose, sarciniform, 4-12-celled, carbonaceous black, septa not visible, slightly constricted at the septa, 16-40 $\mu \mathrm{m}$ in diameter, wall smooth. Thyriothecia scattered, orbicular, cells radiating at the upper portion, up to $200 \mu \mathrm{m}$ in diameter, dissolved at the central portion by exposing asci; asci ovate to globose, eight spored, $30-50 \times 12-$ $22 \mu \mathrm{m}$; ascospores oblong, conglobate, uniseptate, constricted at the septum, 10-20 $\times 9-11 \mu \mathrm{m}$.

On leaves of Tectona grandis L (Verbenaceae), 21 December 1981, C.R. Patil HCIO 36359 (type).

Material examined - India, Karnataka, Jodupal, on leaves of Tectona grandis L. (Verbenaceae), 11 November 2003, V.B. Hosagoudar \& al HCIO 45633, TBGT 1377; 12 November, 2003, V.B. Hosagoudar \& al. HCIO 45613, TBGT 1356; HCIO 45625, TBGT 1368; HCIO 45632, TBGT 1376; Kerala, Pathanamthitta, Placherry forest, Ranni, 4 October 2002, A. Manojkumar HCIO 44656 (holotype of anamorph), TBGT 938 (isotype of anamorph); Thiruvananthapuram, Palode,
TBGRI, 12 August 2004, V.B.Hosagoudar HCIO 46279, TBGT 1925; Thrissur, Vazhachal, Pokalappara, 21 August 2007, Jacob Thomas \& al HCIO 48216, TBGT 2952; Wayanadu, Puthuserrykadavu, 14 March 2007, M.C. Riju HCIO 49978, TBGT 4130; HCIO 49982, TBGT 4134; Padinharathara, 4 November 2009, A. Sabeena \& M.C. Riju TBGT 4796.

Colonies were hyperparasitized by Acremoniula sarcinellae.

Schiffnerula terminaliae Hosag. \& Riju, Indian J. Sci. \& Techn. 2(6): 8, 2009. Questieriella terminaliae Hosag. \& Agarwal, Indian Phytopath. 55: 501, 2002.

(Fig. 68)

Colonies amphigenous, subdense to dense, confluent, up to $6 \mathrm{~mm}$ in diameter. Hyphae straight to sub straight, branching alternate, unilateral to opposite at acute to wide angles, loosely to closely reticulate, cells $13-51$ $\times 2-5 \mu \mathrm{m}$. Appressoria alternate to unilateral, globose, mammiform, entire, 4-11 × 4-9 $\mu \mathrm{m}$. Questieriella conidiophores produced lateral to the hyphae, single, straight to flexuous macronematous, mononematous, 0-3-septate, 18-24 × 6-9 $\mu \mathrm{m}$; conidiogenous, cells terminal, monoblastic, integrated, cylindrical; conidia few, mostly scattered in the colonies, few attached to the conidiophores, curved, 3-septate, slightly constricted at the septa, taper towards both ends, 24-46 × 6-11 $\mu \mathrm{m}$. Thyriothecia scattered, orbicular, ovate, peridial cells initially radiating, later central portion dissolved by exposing the asci, up to $176 \mu \mathrm{m}$ in diameter, marginal cells radiating; asci 3-10 per thyriothecia, oblong to clavate, octosporous, bitunicate, $39-46 \times 15-31 \mu \mathrm{m}$; ascospores oblong, conglobate, uniseptate, constricted at the septum, 17-24 × 6-9 $\mu \mathrm{m}$, remain hyaline for some time but turn brown at maturity, wall smooth.

Material examined - India, Kerala, Thiruvananthapuram, Karakulam, Eanikara, on leaves of Terminalia catappa L. (Combretaceae), 4 February 2001, P.V. Mahanteshagowda HCIO 43808 (holotype of anamorph), TBGT 399 (isotype holotype of anamorph); Kerala, Thiruvananthapuram, Palode, 15 September 2007, M.C. Riju HCIO 48181 (holotype), TBGT 2917 (isotype); Peppara, 4 
Plant Pathology \& Quarantine

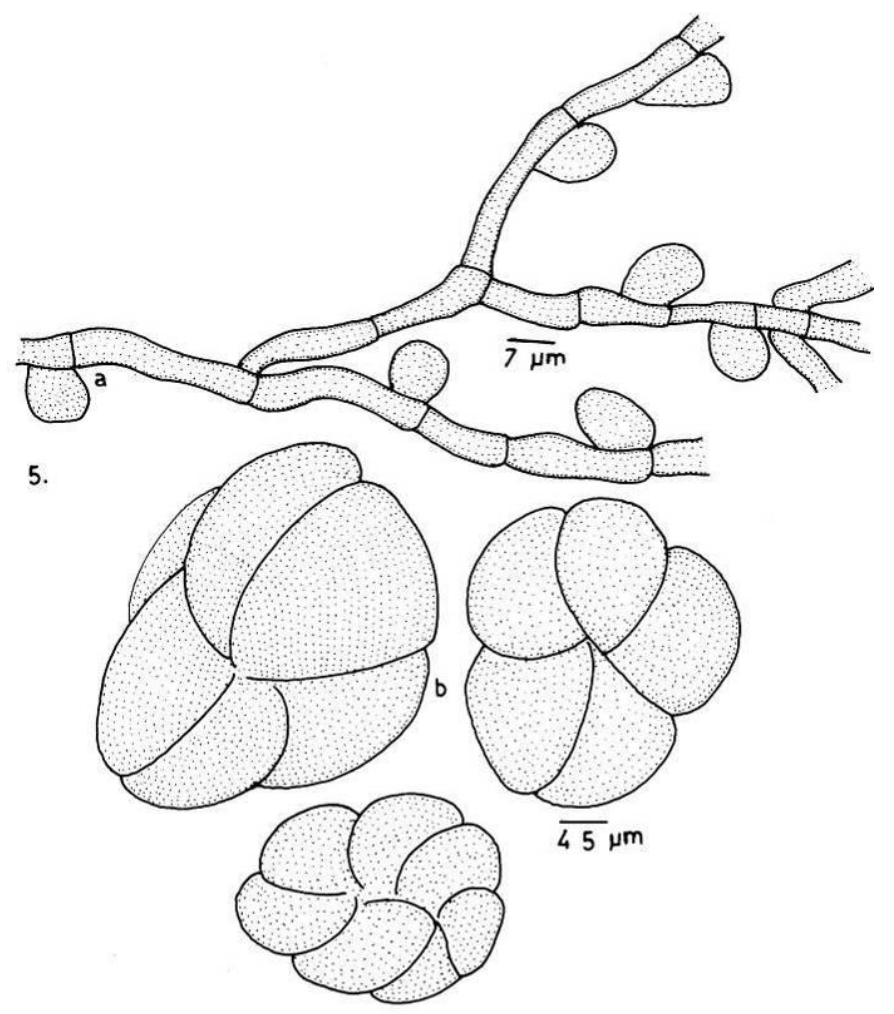

Fig. 67 - Sarcienall state of Schiffnerula tectonae

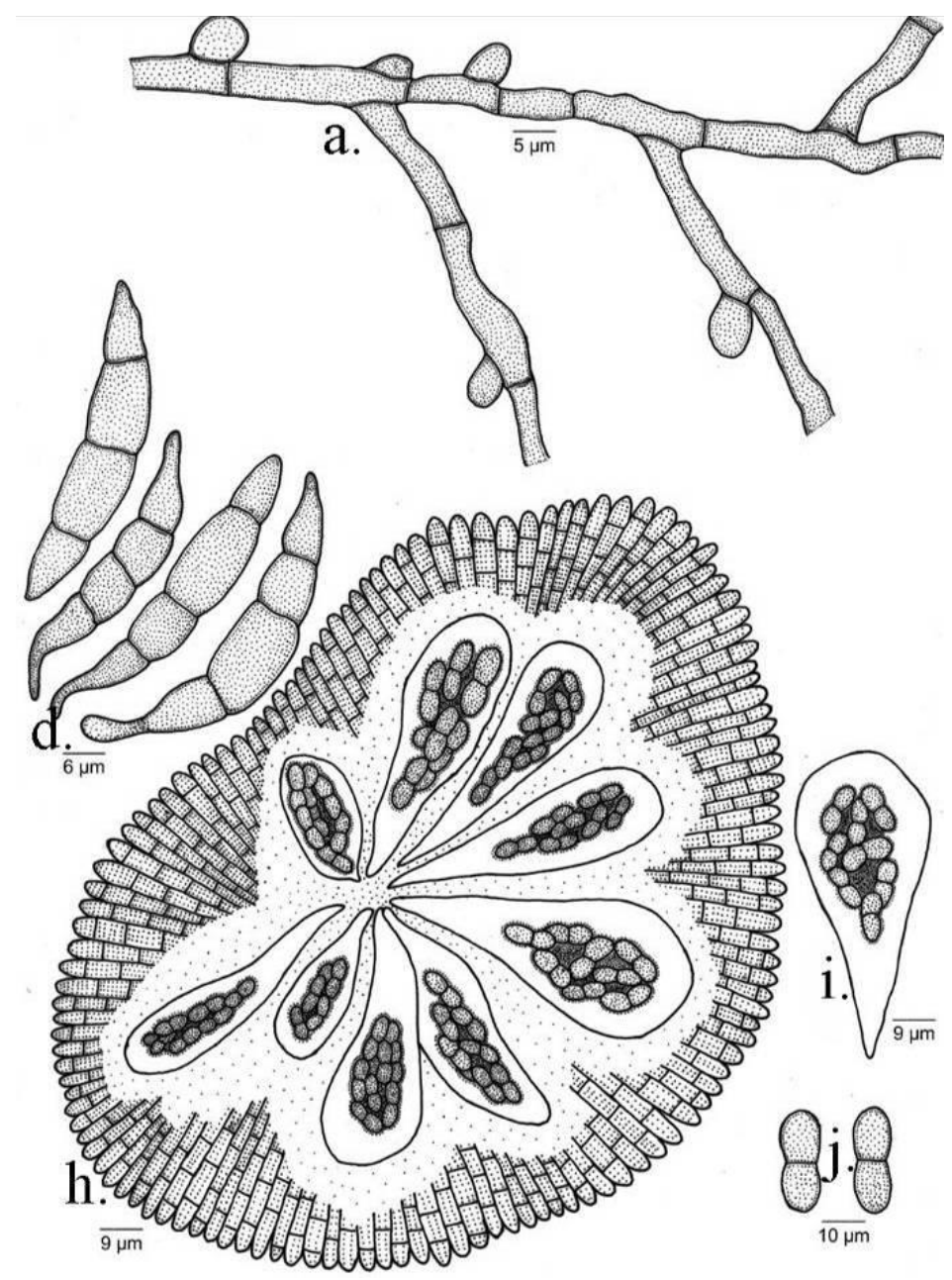

Fig. 68 - Schiffnerula terminaliae 
February1997, V.B. Hosagoudar HCIO 44011, TBGT 462; TBGRI campus, 22 November 2000, C.K.Biju HCIO 44062, TBGT 496; 12 October 2000, V.B. Hosagoudar HCIO 44326, TBGT 626; Nedumangad, Netta, 4 February 2005, P.V. Ishwaragowda HCIO 46177, TBGT 1589; Peringammala, 14 December 2005, V.B.Hosagoudar \& al HCIO 47019, TBGT 2236; HCIO 47026, TBGT 2243; Pathanamthitta, Thiruvalla, Kutta-puzha, 15 November 2006, Jacob Thomas HCIO 47982, TBGT 2765; Nedumagadu, 11 February 2007, Ishwaragouda V. Patil HCIO 49923, TBGT 4075; Kozhikode, Malabar Botanic Garden, 3 November 2009, M.C. Riju \& A. Sabeena TBGT 4744; 4746; Thiruvananthapuram, Palode, TBGRI campus, 5 September 2008, A. Sabeena TBGT 4854; 12 February 2009, A. Sabeena \& M.C. Riju TBGT 4854.

This species was associated with Asteridiella combreti var. leonensis Hansf.

Schiffnerula theissenii Hughes, Can. J. Bot. 62: 2213, 1984. Clypeolella solani Theiss., Centr. Bl. Bkt. II Abt. 24: 233, 1912; Patil, M.S. \& Patil, S.D., Indian J. Mycol. Pl. Pathol. 15: 132-136, 1985.

Colonies amphigenous, grey, scattered, covering entire leaf surface. Hyphae substraight to flexuous, branching opposite to unilateral at acute to wide angles. Appressoria alternate to unilateral, ovate to elliptical, $8-10 \times$ 9-11 $\mu \mathrm{m}$. Conidia of Questieriella scattered, not attached, slightly curved, 3-septate, slightly constricted at the septa, germinate to form colonies, light brown, 26-30 $\times 9$ $11 \mu \mathrm{m}$. Sarcinella conidia borne on a short pedicels, conidia 5-6-celled, sarciniform, black, constricted at the septa, 30-32 $\mu \mathrm{m}$ in diameter. Thyriothecia orbicular, mucus diffluent at maturity, up to $65 \mu \mathrm{m}$ in diameter; asci few to many, aparaphysate, subglobose to broadly ellipsoidal, sessile, 8 -spored, $37-53 \times$ 20-23 $\mu \mathrm{m}$; ascospores brown, uniseptate, constricted at the septum, $16-25 \times 8-10 \mu \mathrm{m}$, rounded at both ends, wall smooth.

On leaves of Solanum sp. (Solanaceae), Radhanagari, Maharashtra.

Schiffnerula triumfetticola (Patil \& patil) Pande, Ascomycetes of Peninsular India, p. 194, 2008. Clypeolella triumfetticola Patil,
M.S. \& Patil, S.D., Indian J. Mycol. Pl. Pathol. 15: 132-136, 1985.

Colonies amphigenous, grey, scattered, covering entire leaf surface. Hyphae substraight to flexuous, branching opposite to unilateral at acute to wide angles, cells 5-7 $\mu \mathrm{m}$ wide. Appressoria alternate to unilateral, ovate to obpyriform, $10-12 \times 6-8 \mu \mathrm{m}$. Conidia of Questieriella scattered, not attached, slightly curved, 3-septate, slightly constricted at the septa, germinate to form colonies, light brown, $26-33 \times 11-13 \mu \mathrm{m}$. Sarcinella conidia borne on a short pedicels, conidia 5-6celled, sarciniform, black, constricted at the septa, 30-33 $\mu \mathrm{m}$ in diameter. Thyriothecia orbicular, mucus diffluent at maturity, up to 76 $\mu \mathrm{m}$ in diameter; asci few to many, aparaphysate, subglobose to broadly ellipsoidal, sessile, 8-spored, 30-34 × 20-26 $\mu \mathrm{m}$; ascospores brown, uniseptate, constricted at the septum, $18-20 \times 8-10 \mu \mathrm{m}$, rounded at both ends, wall smooth.

On leaves of Triumfetta rotundifolia Lam. (Tiliaceae), Ajara, Kolhapur, Maharashtra.

Schiffnerula vernoniae Hosag., Sabeena \& Riju, Indian Phytopath. 63: 3231, 2010. Sacinella vernoniae (Dearn. \& Barth.) Hughes, Can. J. Bot. 61: 1748, 1983. Hosag., C.K. Biju \& Abraham, J. Econ. Taxon. Bot. 25: 281, 2001. Stigmella vernoniae Dearn. \& Barth., Mycolgia 21: 330, 1929. Piricauda vernoniae (Dearn. \& Barth.) Moore, Rhodora 61:106, 1959.

(Figs 69-70)

Colonies epiphyllous, thin, up to $2 \mathrm{~mm}$ in diameter, confluent. Hyphae substraight to undulating, branching alternate, unilateral to opposite at acute to wide angles, loosely reticulate, cells 7-38 × 5-7 $\mu \mathrm{m}$. Appressoria scattered, alternate, unilateral, opposite to subopposite, globose, mammiform, entire, 7-13 × 7$12 \mu \mathrm{m}$. Conidia of Questieriella scattered, 3septate, straight, slightly constricted at the septa, taper towards both ends, 30-35 × 10-13 $\mu \mathrm{m}$. Sarcinella conidiophores produced lateral to the hyphae, single, straight, flexuous, micronematous, mononematous, 8$14 \times 5-7$, conidiogenous cells terminal, monoblastic, integrated, cylindrical. Sarcinella conidia blastic, terminal, mostly sessile, solitary, dry, ovate to globose, sarciniform, 


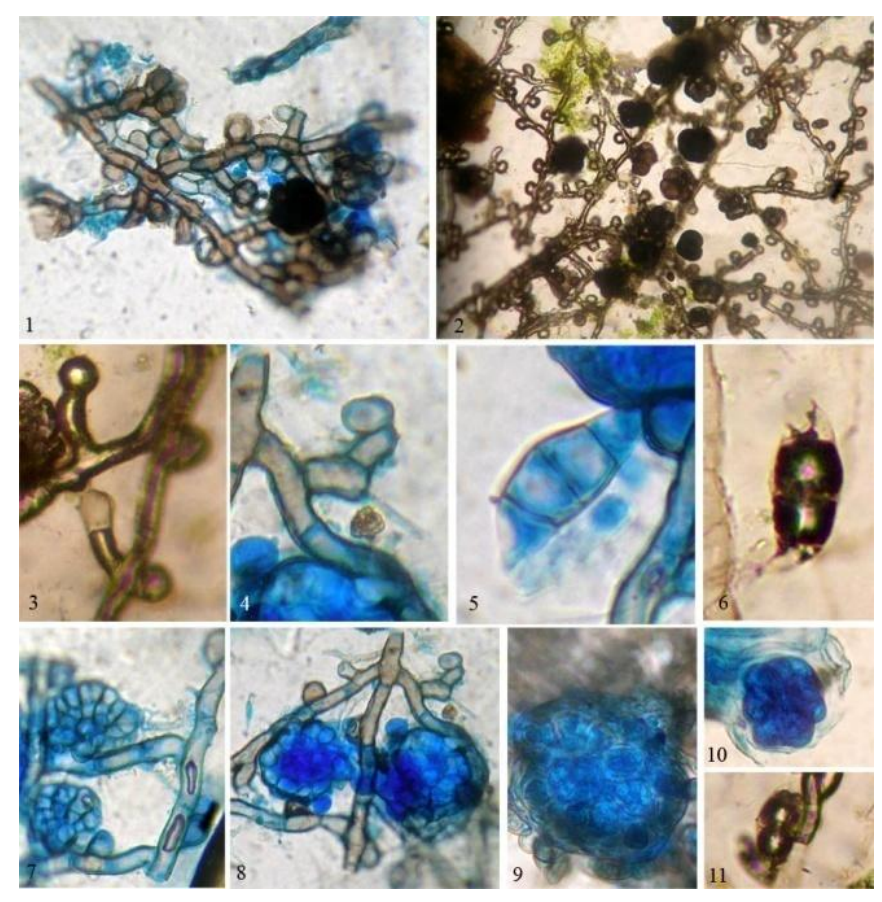

Fig. 69 - Schiffnerula vernoniae, 1 Appressoriate mycelium, 2 Mycelium with Sarcinella conidia, 3-4 Conidiophore of Sarcinella, 5-6 Questieriella conidia, 7-8 Developmental stages of thyriothecium, 9 Thyriothecium with asci, 10 Ascus, 11 Ascospore.

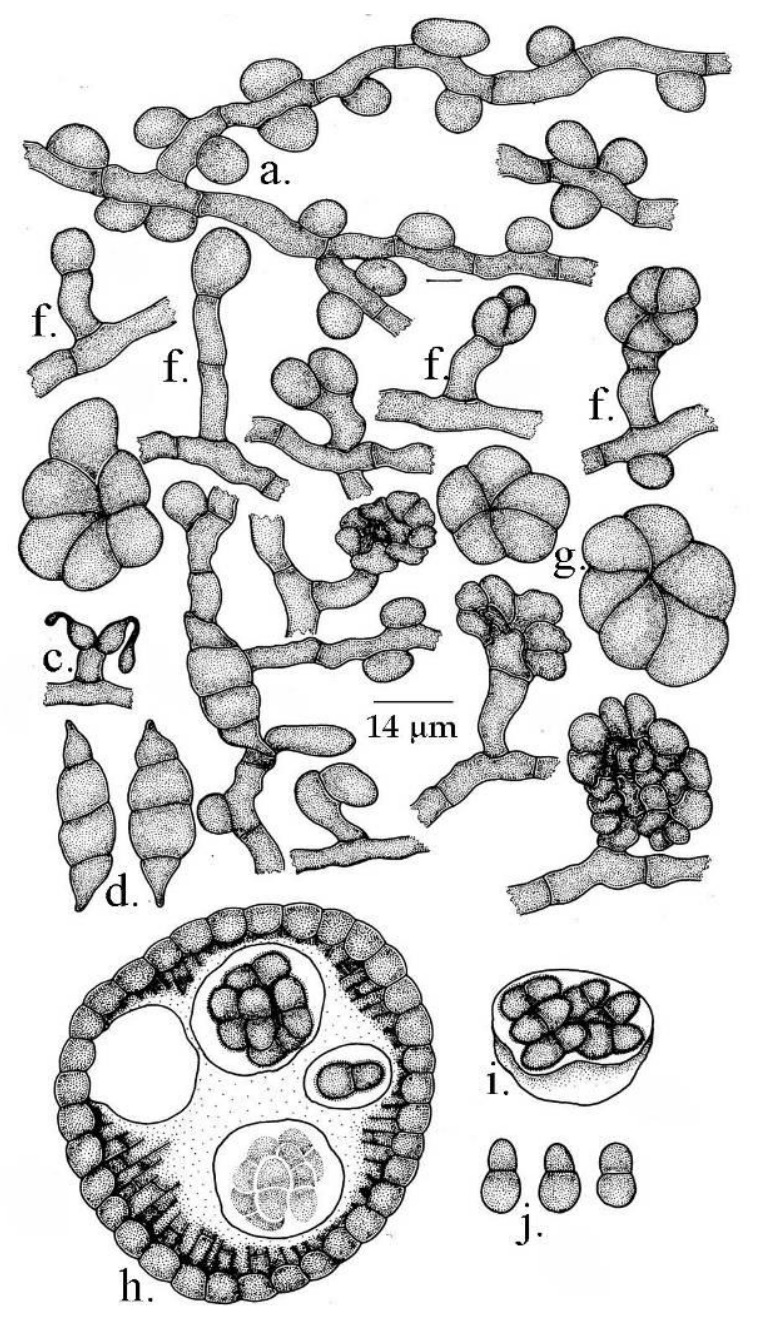

Fig. 70 - Schiffnerula vernoniae 
2-7 celled, constricted at the septa, 30-38 $\mu \mathrm{m}$ in diameter, wall smooth. Thyriothecia scattered, ovate, orbicular, peridial cells initially radiating, later central portion dissolved by exposing the asci, up to $83 \mu \mathrm{m}$ in diameter, marginal cells radiating; asci $2-4$ per thyriothecia, globose, octosporous, 20-23 $\mu \mathrm{m}$ in diameter; ascospores oblong, conglobate, uniseptate, constricted at the septum, 20-25 $\times$ 10-13 $\mu \mathrm{m}$, wall smooth.

Material examined - India, Kerala, Wayanad, Padinharathara, on leaves of Vernonia anthelmintica (L.) Willd. (Asteraceae), 23 December 2008, M.C. Riju HCIO 49105 (holotype), TBGT 3360 (isotype). Anamorphs: Kerala, Idukki, Banasuran mala, on leaves of Vernonia peninsularis (Clarke) Clarke ex Hook. f., 19 November, 1999, C.K. Biju HCIO 43462, TBGT 267; Wayanad, Chandanathode, on leaves of $V$. conyzoides DC., 12 December 2002, M. Kamarudeen \& P.A. Jose HCIO 44789, TBGT 1026; Silent valley, Sairandhri, on leaves of Vernonia sp., 13 December 2003, V.B. Hosagoudar \& al. HCIO 45766, TBGT 1515; 13 December 2003, V.B. Hosagoudar \& al. HCIO 45818, TBGT 1568.

Because of the sarciniform conidia, Moore (1959) placed Stigmella vernoniae under the genus Piricauda. Subsequently, Hughes (1983) placed it under the genus Sarcinella. In our recent collection, we could get the perithecial state.

Schiffnerula wedeliae Hosag., Sabeena \& Riju, Indian Phytopath. 63: 324, 2010.

(Figs 71-73)

Colonies amphigenous, thin, up to $3 \mathrm{~mm}$ in diameter, confluent. Hyphae pale brown, substraight to flexuous, branching opposite to unilateral at acute to wide angles, loosely to closely reticulate, cells $15-30 \times 5-7 \mu \mathrm{m}$. Appressoria unicellular, alternate to unilateral, globose, ovate, entire, 7-15 × 7-12 $\mu \mathrm{m}$. Conidia of Questieriella were scattered but very few were attached to hyphae, light brown, slightly curved, 3-septate, slightly constricted at the septa, many are germinating, $32-45 \times 10-12 \mu \mathrm{m}$, wall smooth. Conidia of Sarcinella not seen. Thyriothecia scattered, orbicular, often connate, initially radiating, later central portion dissolved by exposing the asci, $52-87 \mu \mathrm{m}$ in diameter, marginal cells radiating; asci 1-4 per thyriothecia, globose, ovate, octosporous, 15-37 $\mu \mathrm{m}$ in diameter; ascospores oblong, conglobate, uniseptate, constricted at the septum, $15-25 \times 7-12 \mu \mathrm{m}$.

Material examined - India, Kerala, Thiruvananthapuram, Palode, TBGRI Campus, on leaves of Wedelia chinensis (L.) Merr. (Asteraceae), 24 June 2008, A. Sabeena TBGT 3226 (holotype), HCIO 48850 (isotype); 26 June 2008, A. Sabeena TBGT 3227, HCIO 48851; 15 October 2008, A. Sabeena TBGT 3372, HCIO 49117; 15 October 2008, A. Sabeena TBGT 5113.

Eight species of the genus Schiffnerula are known on members of the family Asteraceae (Hughes 1984, Hosagoudar 2003b). Of these, $S$. wedeliae is close to M. milleriae Sydow but differs from it in having longer conidia of Quisteriella and in absence of Sarcinella conidia.

Schiffnerula ziziphi (Yates) Hughes, Pleomorphy in some hyphopodiate fungi, p. 134, 1987. Asterina ziziphi Yates, Phillipine J. Sc. C. Bot. 13: 375, 1918 (zizyphiae). Clypeolella ziziphi (Yates) Hansf., Proc. Linn. Soc. London 160: 152, 1949. Clypeolella ziziphina Thaung, Trans. Brit. Mycol. Soc. 63: 622, 1974 (zizphina). Schiffnerula ziziphina (Thaung) Hughes, Can. J. Bot. 62: 1842, 1984. (Fig. 74)

Anamorph - Mitteriella ziziphina Sydow, Ann. Mycol. 31:95, 1933; Sahni, Mycopath. Mycol. Appl. 3-4: 337, 1966.

Colonies amphigenous, mostly epiphyllous, without spots, at first minute, then more or less effuse, becoming confluent and occupying a major part of leaf or the entire leaf, black; if hyphophyllous thin, scattered, up to 2 $\mathrm{mm}$ in diameter, found on the margin or close to the veins. Hyphae straight to substraight, branching opposite to alternate at acute angles, loosely reticulate, cells $17-40 \times 5-8 \mu \mathrm{m}$. Appressoria unicellular, globose, ovate, entire, alternate, unilateral, rarely arranged closely to form bicellular, 7-10 × 7-11 $\mu \mathrm{m}$. Conidiophores produced lateral to the hyphae, micronematous, mononematous, 20-92 × 5-8 $\mu \mathrm{m}, 2-3$ septate; conidia ellipsoidal, ovateellipsoidal, gradually but distinctly narrowing towards both ends, at first continuous, 1-2 septate by dividing the spore into unequal cells, rarely 4-septate, dark to 
Plant Pathology \& Quarantine
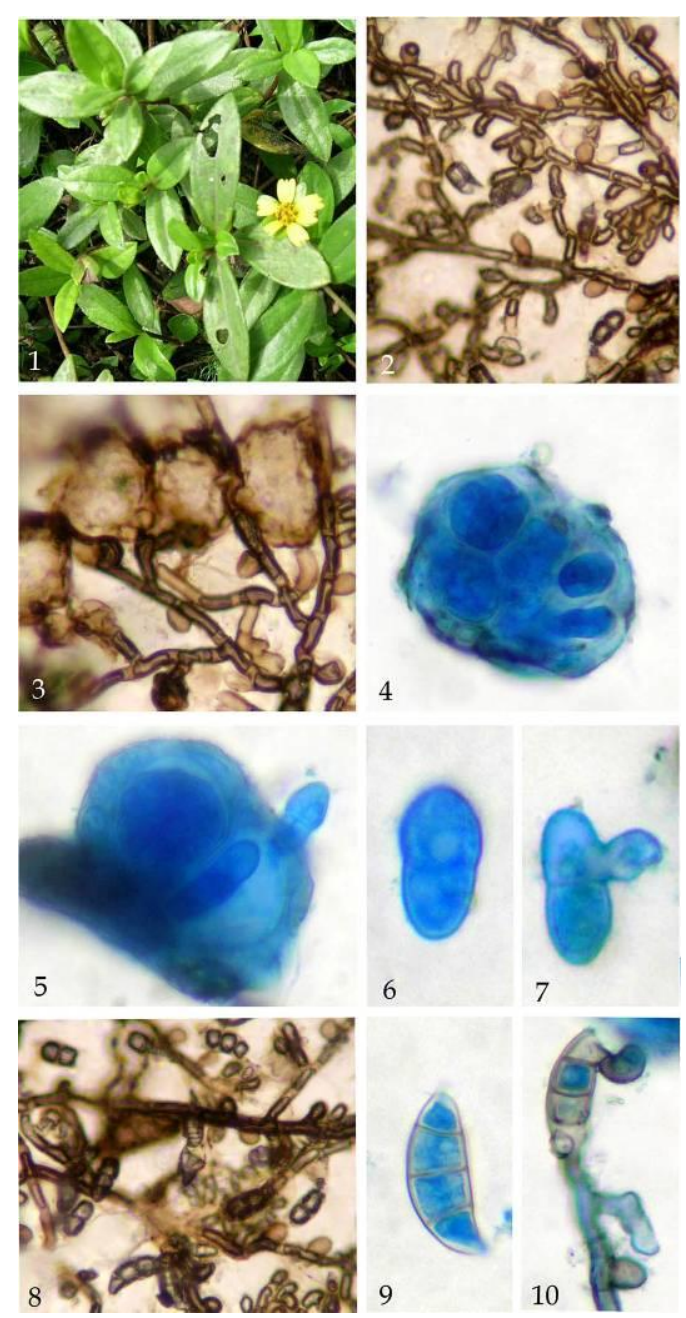

Fig. 71 - Schiffnerula wedeliae, 1 Infected leaves, 2 Branched mycelium, 3 Appressoriate mycelium with thyriothecia, 4-5 Thyriothecia with with exposed asci, 6-7 Ascospores, 8-9 Questieriella conidia, 10 Germinating Questieriella conidia

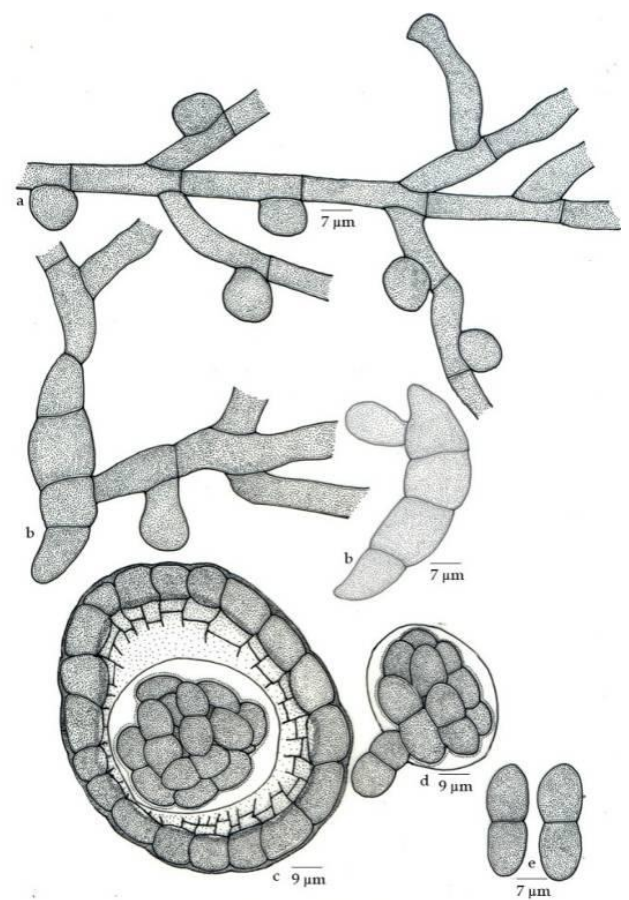

Fig. 72 - Schiffnerula wedeliae 

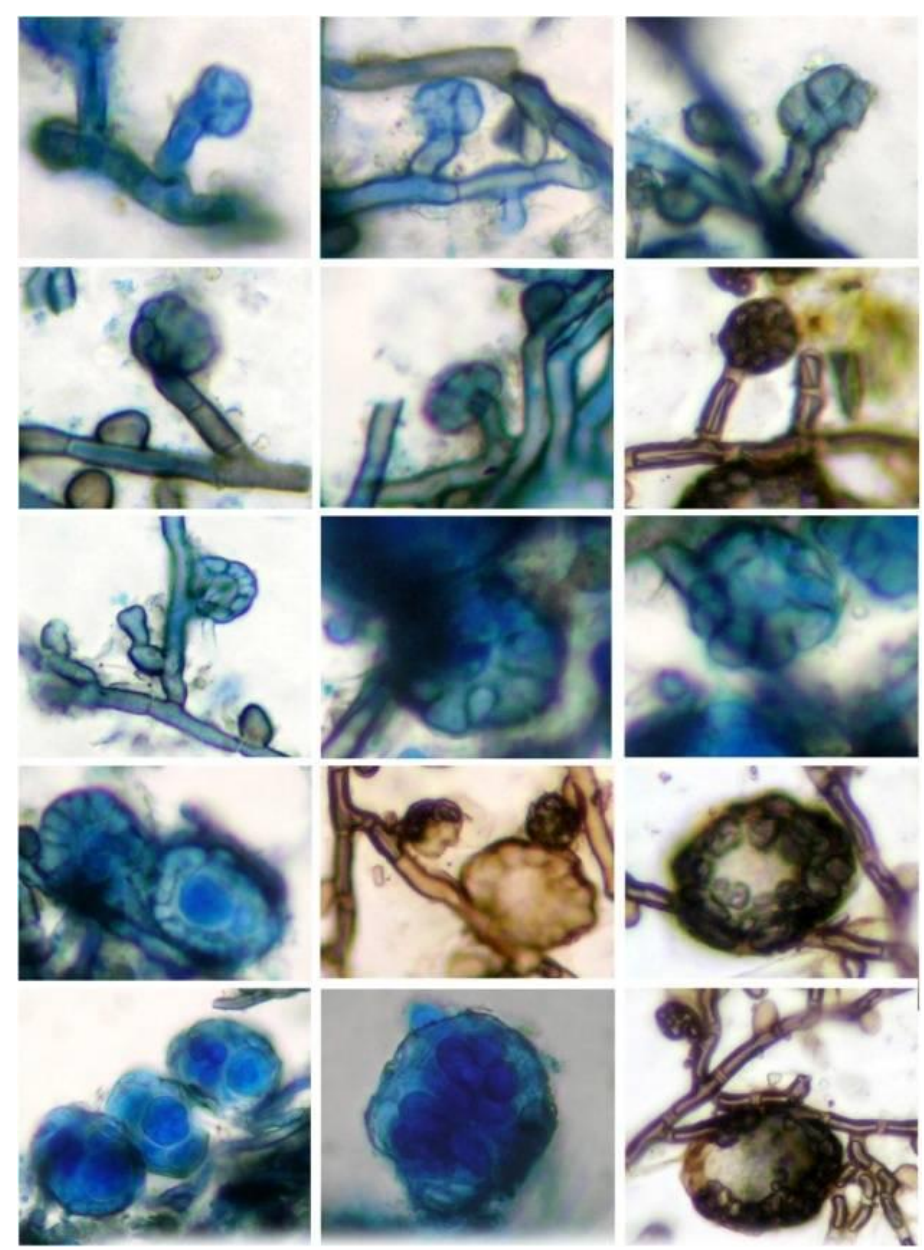

Fig. 73 - Development of ascoma in Schiffnerula wedeliae

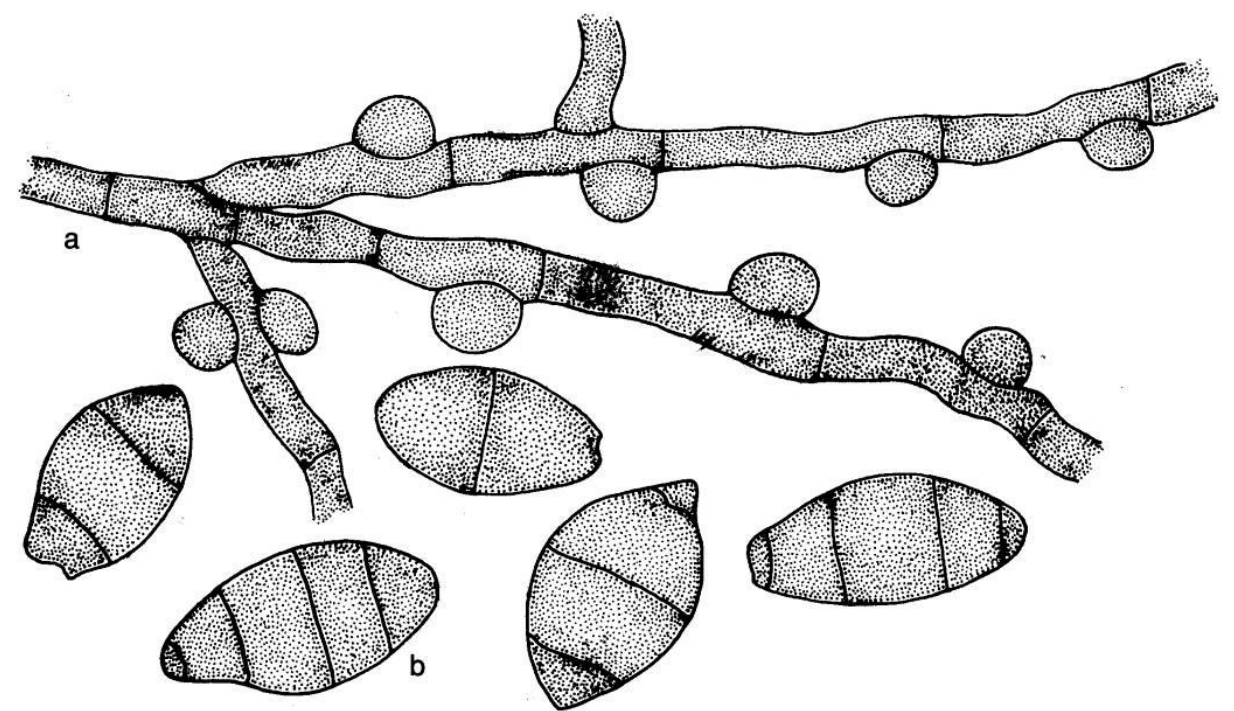

Fig. 74 - Mitteriella state of Schiffnerula ziziphi

opaque brown, smooth, thick walled, 22-35 $\times$ 15-17 $\mu \mathrm{m}$. Thyriothecia scattered, orbicular, up to $260 \mu \mathrm{m}$ in diameter, upper layer with radiating cells, margin crenate to slightly fimbriate, gelatinise at the centre by exposing the asci; asci numerous, ovoid to subglobose, 8spored, 20-40 $\mu \mathrm{m}$ in diameter; ascospores congobate, brown, oblong to clavulate, 16$24 \times 8-14 \mu \mathrm{m}$, uniseptate, constricted at the septum, rounded at both ends, wall smooth. 
Material examined - India, Uttar Pradesh, Maharajganj, on leaves of Ziziphus latifolia (Rhamnaceae), M.A. Nomani TBGT 3528; Z. nummularia a (Burm.f.) Wight \& Arn., Maharajganj Uttar Pradesh, M.A. Nomani TBGT 3529. Z. xylopyrus (Retz.) Willd. (Rhmnaceae), Gorakhpur, Uttar Pradesh, P. Abbasi 112, IMI 247422; Ziziphus oenoplia L. Mill., Ziziphus xylopyrus (Retz.) Willd., Kundan road, April 1962, IMI 96668.

\section{Acknowledgements}

This work was carried out both in Botanical Survey of India and Tropical Botanic Garden and Research Institute since 1981. Grateful thanks to heads of both the institutions for providing facilities and associated angiosperm taxonomists for identifying the host plants. I gratefully acknowledge Dr. McKenzie, Senior Scientist, Thailand for reviewing the script.

\section{References}

Arx JA von, Muller E. 1975 - A re-evaluation of the bitunicate ascomycetes with key to the families and genera. Studies in Mycology 9, 1-159.

Chandra S, Srivastava N, Chaudhary R. 1991 New species of Sarcinella from India. Indian Phytopathology 44, 301-307.

Ciferri R. 1938 - Mycoflora domingensis exsiccate (cent. III no. 201-300). Annales Mycologici 36, 198-245.

Deighton FC. 1944 - West African Meliolineae I. Meliolineae on Malvaceae and Tiliaceae. Mycological Papers 9, 1-24.

Dilcher DL. 1965 - Epiphyllous fungi from Eocene deposits in Western Tennessee, USA. Palaeontographica 116, 1-50.

Doidge EM. 1942 - A revision of the South African Microthyriaceae. Bothalia 4, 273-344.

Hansford CG. 1941a - Contribution towards the fungal flora of Uganda II. Some Uganda Ascomycetes. Proceedings of Linnean Society London 19, 14-52.

Hansford CG. 1941b - Contribution towards the fungal flora of Uganda III. Some Uganda Ascomycetes. Proceedings of Linnean Society London 1, 4-52.
Hansford G. 1946 - The foliicolous Ascomycetes, their parasites and associated fungi. Mycological Papers 15, 1-240.

Hansford CG. 1949 - Tropical fungi III. New species and revision. Proceedings of Linnean Society London 160, 116-153.

Hansford CG. 1954 - Some Microthyriales and other fungi from Indonesia. Reinwardtia $3,113-144$.

Hosagoudar VB. 2003a - Studies on foliicolous fungi-XIII. A new genus and a new species. Zoos’ Print Journal 18, 1159-1162.

Hosagoudar VB. 2003b - The genus Schiffnerula and its synanamorphs. Zoos' Print Journal 18, 1071-1078.

Hosagoudar VB, Abraham TK, Biju CK. 1996 - Some interesting hyphomycetes from southern India. New Botanist 23, 211218.

Hosagoudar VB, Kapoor JN. 1984 - New Technique of mounting Meliolaceous fungi. Indian Phytopathogy 38, 548-549.

Hosagoudar VB, Mohanan M. 1995 - A note on Sarcinella lagerstroemiae sp. nov. from Andhra Pradesh. New Botanist 22, 31-33.

Hosagoudar VB, Abraham TK, Biju CK. 1999 - Notes on some foliicolous fungi from Kerala, India. Journal of Mycopathological Research 37, 25-28.

Hosagoudar VB, Biju CK, Abraham TK, Agarwal DK. 2002 - Studies on foliicolous fungi III. Indian Phytopathology. 55, 497502.

Hosagoudar VB, Biju H, Anu Appaiah KA. 2006 - Studies on foliicolous fungi XX. Microfungi of Coorg, Karnataka. Journal of Mycopathological Research 44, 1-25.

Hughes SJ. 1983 - Five species of Sarcinella from North America, with notes on Questieriella n. gen., Mitteriella, Endophragmiopsis, Schiffnerula, and Clypeolella. Canadian Journal of Botany 61, 17271767.

Hughes SJ. 1984 - Schiffnerulaceous fungi on Compositae from the Americas. Canadian Journal of Botany 62, 2213-2222.

Hughes SJ. 1987 - Pleomorphy in some hyphopodiate fungi. In: Pleomorphic Fungi (ed. Y Sugiyama). The diversity and its taxonomic implications. Kodansa \& Elsevier, Tokyo. 103-139. 
Kamal RP, Singh RP. 1980 - Fungi of Gorakhpur XVII. Sarcinella. Sydowia 33, 152156.

Katumoto K. 1975 - The Hemisphaeriales in Japan. Bull. Fac. Agric. Yamaguti Univ. $26,45-122$.

Kranz J. 1966 - New hyphomyceten aus Guinea. Sydowia 20, 211-215.

Mandal A, Samajpati N, Bera S. 2011 - A new species of Meliolinites (fossil Meliolales) from the Neogene sediments of SubHimalayan West Bengal, India. Nova Hedwigia 92, 435-440.

Martin HA, Rouse GE. 1966 - Palynology of late tertiary sediments from Queen Charlotte Island, British Columbia. Canadina Journal of Botany 44, 177-208.

Meenu Singh SK, Chaudhary RK. 1994 - New species and new records of Sarcinella from Nepal Himalayas. Journal of Living World 1, 106-111.

Moore RT. 1959 - The genus Piricauda (Deuteromycetes). Rhodora 61, 87-120.

Munjal RL, Kapoor JN. 1963 - Hyphomycetes from Himalayas. Indian Phytopathology $16,86-91$.

Orejuela CG. 1944 - New and hitherto unreported species of higher Ascomycetes from Columbia and Venezuela. Mycologia 36, 429-529.

Ramakrishnan TS, Sundaram NV. 1953 - Additions to fungi of Madras XV. Proceedings of Indian Academy of Science 38, 187-194.

Saccardo PA. 1875 - Fungi veneti novi vel critici, series Nuovo. Giornale Botanico of Italiano 7, 299-329.

Sahni VP. 1964 - Some foliicolous ectoparasites and associated fungi from Jabalpur,
M.P. I. Mycopathology et Mycological Applicata 23, 328-338.

Sahni VP. 1966 - Deuteromycetes from Jabalpur II. Mycopathology et Mycological Applicata 29, 224-226.

Santapau H, Henry AN. 1971 - A Dictionary of Flowering Plants of India. Publication Information Directory, CSIR, New Delhi.

Sivanesan A. 1984 - The Bitunicate Ascomycetes. International Books \& Periodical Supply Service, New Delhi.

Srivastava N Chandra S, Gupta C. 1990 - New species of foliicolous hyphomycete genus Sarcinella. Vegetos 3, 74-82.

Subhedar AW, Rao VG. 1975 - Some interesting fungi from Western India. Biovigyanam 1, 191-196.

Sydow H. 1930a - Fungi Venezuelani. Annales Mycologici 28, 29-224.

Sydow H. 1930b - Novae fungorum species XX. Annales Mycologici 28, 432-447.

Sydow H, Sydow P. 1914 - Fungi from northern Palawan. Philippine Journal Science 9, 157-189.

Sydow H, Sydow P, Butler EJ. 1911 - Fungi Indiae Orientalis. Annales Mycologici 9, 372-421.

To-Anun C, Hydayat I, Meeboon J. 2011. Genus Cercospora in Thailand - Taxonomy and Phylogeny (with a dichotomous key to species). Plant Pathology \& Quarantine $1,11-87$.

Verma RC, Tripathi MS, Chaudhary RK. 1999 - Three new black mildews from forest flora of north-eastern Uttar Pradesh. Indian Phytopathogy 52, 377-380.

Yamamoto W. 1957 - The Formosan species of Microthyriaceae II. Science Reports of the Hyogo University of Agriculture 3, 23-31. 